\title{
V. Brückenschlag zwischen Krieg und Frieden: Arbeiten zur amerikanischen Besatzungs- und Nachkriegspolitik in Deutschland
}

\section{Planungen und Vorbereitungen für die Militärregierung}

Die von Zeitgenossen wie Historikern vielfach geäußerte Kritik, daß die Amerikaner nicht ausreichend auf die komplexe Aufgabe vorbereitet gewesen seien, die Verwaltung und Regierung eines nach seiner bedingungslosen Kapitulation in fast völliger Desintegration befindlichen Deutschlands zu übernehmen ${ }^{1}$, zielt zwar in erster Linie auf das Fehlen einer klaren politischen Konzeption ab, verstellt aber auch leicht den Blick auf die Arbeit der zahlreichen Planungsstäbe, die in Washington sowie in den amerikanischen Militärbasen in Großbritannien mit Vorbereitungen für die amerikanische Militärregierung in Deutschland befaßt waren ${ }^{2}$. Freilich fand die Arbeit dieser Planungsstäbe unter den ungünstigsten Bedingungen statt ${ }^{3}$. Die Zuständigkeiten der verschiedenen Ministerien und der von ihnen gebildeten Gremien blieben lange ungeklärt, die Koordination ihrer Arbeit war mangelhaft, und die von Roosevelt betriebene "policy of postponement" ließ auch die Washingtoner Behörden fast bis zum Ende des Krieges darüber im unklaren, unter welchen Rahmenbedingungen die amerikanische Militärregierung in Deutschland zu operieren haben würde. Die Intervention Finanzminister Morgenthaus im Sommer 1944 und sein zunächst so erfolgreicher Versuch, in diesem fortgeschrittenen Stadium des Krieges noch eine drastische Revision aller bisherigen Planungen zu erreichen, machte deutlich, wie unsicher selbst der Einfluß so gewichtiger Ministerien wie des State und War Department auf den amerikanischen "decision making process" war.

Im War Department versuchte man zunächst, die politischen Fragen und Probleme, die sich bei der Planung und Vorbereitung der amerikanischen Militärregierung in Deutschland stellten, soweit wie möglich zu ignorieren und sich statt dessen auf diejenigen Bereiche zu konzentrieren, die man als eindeutig militärische Kompetenz und Verantwortung ansah. Allerdings zeigte sich bald, daß die angestrebte politische Abstinenz kaum möglich war. Schon die Vorstellungen über Aufgaben und Methoden künftiger amerikanischer Militärregierungen, die an der seit Frühjahr 1942 bestehenden School of Military Government an der University of Virginia in Charlottesville entwickelt wurden, erregten wegen der Priorität, die "military necessity" nun vor

${ }^{1}$ Die zeitgenössische Kritik wird z. B. angesprochen in Clay, Entscheidung in Deutschland, S.25, vgl. auch S.31. Zur Haltung in der älteren Fachliteratur siehe z.B. die Einleitung bei Gimbel, The American Occupation. Eine pointiert formulierte Kritik an der Planung der amerikanischen Besatzungs- und Deutschlandpolitik findet sich bei Peterson, The American Occupation, S.19-35; weitgehend negativ zum allgemeinen politischen Führungssstil Roosevelts: Marks III, Wind Over Sand.

${ }^{2}$ Vgl. dazu Zink, American Military Government, S. 263.

${ }^{3}$ Vgl. dazu z. B. Hammond, Directives for the Occupation of Germany, in: Stein (Hrsg.), American Civil-Military Decisions, S.311-460. 
dem bislang fast gleichberechtigten "welfare of the governed" erhielt, scharfe Kritik; die Presse sprach gar von einer "school for Gauleiters" ${ }^{4}$, und auch der Präsident äußerte Mißfallen. Angesichts der in Nordafrika und später in Italien gesammelten Erfahrungen schien es jedoch unabdingbar, zivile Regierungs- und Verwaltungsfunktionen in befreiten bzw. besetzten Gebieten auch nach Abschluß der Kampfhandlungen noch für mehrere Monate in der Verantwortlichkeit des Militärs zu belassen.

Für die notwendigen Planungen war seit Anfang März 1943 die im War Department neu eingerichtete Civil Affairs Division (CAD) zuständig ${ }^{5}$. Was die Vorbereitung der amerikanischen Besatzungspolitik für Deutschland anlangte, so hatte die CAD eine reichlich undankbare Aufgabe vor sich. Da von Anfang an kaum Zweifel daran bestehen konnten, daß die Siegermächte gegenüber einem besiegten Deutschland als dem Staat, der den Krieg begonnen hatte, eine ganze Reihe von Forderungen erheben würden, schien es fraglich, ob die amerikanische Militärregierung in Deutschland nur ein möglichst kurzfristiges Provisorium zur Abwicklung des Krieges sein konnte, wie es den Idealen des War Department entsprochen hätte ${ }^{6}$. Doch da grundlegende politische Richtlinien fehlten, sah sich die CAD gezwungen, Planungen und Vorbereitungen für die amerikanische Besatzungsherrschaft in Deutschland zu beginnen, ohne eigentlich recht zu wissen, worin deren Aufgaben im einzelnen bestehen würden. Gleichzeitig bot dieses von der "policy of postponement" belassene Vakuum den Planern im War Department freilich auch die keineswegs unwillkommene Chance, diese Aufgaben im Sinne der von ihnen angestrebten "limited liability“ selbst zu definieren ${ }^{7}$.

Zur Bewältigung der im Rahmen dieser Planungen anfallenden Arbeiten versicherte sich CAD-Chef General John H. Hilldring der Unterstützung einer Reihe von Wash-

${ }^{4}$ Zit. nach Ziemke, Improvising Stability and Change, in: Wolfe (Hrsg.), Americans as Proconsuls, S. 53; vgl. auch Holborn, American Military Government, S. 4; zur Entwicklung grundlegender Richtlinien für amerikanische Militärregierungen während des zweiten Weltkriegs siehe Ziemke, The U.S. Army in the Occupation of Germany, S. 3 ff., und Fainsod, The Development of American Military Government Policy, in: Friedrich (u. a.), American Experiences in Military Government, S. 23-51. Zur Kritik an den in Charlottesville entwickelten Richtlinien siehe auch Hammond, Directives, in: Stein (Hrsg.), American Civil-Military Decisions, S. 319f. Zum Ausbildungsprogramm in Charlottesville und anderen Trainingsschulen der Armee Zink, American Military Government, S. $6 \mathrm{ff}$., sowie ders., The United States in Germany, S. $10 \mathrm{ff}$.

${ }^{5}$ Siehe dazu Federal Records of World War II, Bd. II, Military Agencies, S. 128ff.; sowie Holborn, American Military Government, S.8, und Ziemke, The U.S. Army in the Occupation of Germany, S.14ff.

${ }^{6}$ In Darstellungen, die vor allem die Kompetenzstreitigkeiten zwischen den verschiedenen Washingtoner Ministerien betonen, wird das grundsätzliche Interesse des War Department an einer strikten zeitlichen wie inhaltlichen Begrenzung der Aufgaben der Militärregierung nicht immer deutlich. Freilich stand diese Haltung einer energischen Verteidigung der vom War Department vertretenen Konzeptionen und der als Verantwortung des War Department betrachteten Kompetenzen nicht entgegen. Vgl. dazu z.B. Holborn, American Military Government, S. 11 ff.; Dorn, The Debate Over American Occupation Policy, in: PSQ 72/4 (1957), S. 481-501, besonders S.487 (deutsch in VfZ 1958/1, S.60-77); sowie Gimbel, Governing the American Zone of Germany, in: Wolfe (Hrsg.), Proconsuls, S.92ff., und Clays Bestätigung, ebenda, S. 112; vgl. auch ders., Administrative Konflikte, in: Foschepoth (Hrsg.), Kalter Krieg und Deutsche Frage, S. $111 \mathrm{ff}$.

7 Mit dem Begriff der „limited liability theory“ hat Dorn die Vorstellungen des War Department charakterisiert, vgl. Dorn, Debate Over American Occupation Policy, PSQ 72/4 (1957), S.481501 , besonders S. 487. 
ingtoner Behörden, darunter auch der Mitarbeit von R\&A. In einem entsprechenden Abkommen vom Juli 1943 wurden zwei Aufgabenbereiche für R\&A definiert: „(a) The provision of material in response to spot requests; (b) The formulation of suggestions for the solution of certain of the basic problems of civil affairs policies through the preparation of memoranda and conferences of members of CAD and R. \& A. “8 Außerdem wurde Hajo Holborn, der als Verbindungsmann zwischen CAD und R\&A fungierte, mit der Entwicklung eines „comprehensive program of research and analysis on fundamental problems in civil affairs" betraut.

Letztere Bestimmung ermöglichte es R\&A im Rahmen der vorgegebenen Sachzwänge, Umfang und Inhalt der zu leistenden Arbeit selbst zu bestimmen und damit unter Umständen auch einen gewissen Einfluß auf Schwerpunkte oder Bandbreite der Planungen zu nehmen. Durch die Beteiligung an diesem Projekt war es der Abteilung zudem gelungen, sich einen Anteil an der Planung und Vorbereitung der amerikanischen Besatzungspolitik zu sichern, was mit Blick auf das unsichere Nachkriegsschicksal des OSS nicht unvorteilhaft erscheinen mochte9. Wie sich allerdings bald herausstellte, war dieses Projekt nicht nur ungeheuer arbeitsintensiv - allein die Europe-Africa Division war im ersten Halbjahr 1944 fast ausschließlich damit beschäftigt -, sondern auch reichlich problematisch.

Dabei war der Umfang der anfallenden Arbeiten freilich ganz wesentlich durch das von Holborn im Herbst 1943 vorgelegte Arbeitsprogramm bestimmt, das allein für Deutschland die Ausarbeitung von 80 Civil Affairs Guides vorsah ${ }^{10}$. Diese Verwaltungsführer, die als handliche, meist nicht mehr als 20 Seiten umfassende Broschüren geplant waren, sollten ein breites Spektrum von administrativen, wirtschaftlichen und politischen Problemen behandeln, mit denen die Militärregierung während der Besatzung Deutschlands konfrontiert sein würde. An der Ausarbeitung dieser Führer waren neben R\&A noch einige andere Behörden beteiligt, darunter vor allem das State Department und die Foreign Economic Administration (FEA), eine neue Behörde, die im September 1943 eingerichtet worden war, um die Funktionen einer Reihe von Washingtoner Behörden zu konsolidieren, die mit verschiedenen wirtschaftlichen und wirtschaftspolitischen Aspekten des Krieges befaßt waren.

${ }^{8}$ NA, RG 226, E 1, b 2, f: Civil Affairs Division.

9 Nach Darstellung von Katz, Foreign Intelligence, S.70, hatte R\&A diesen Auftrag hauptsächlich der Initiative Holborns zu verdanken. Tatsächlich hatte man im War Department eine Beteiligung von R\&A an den Planungen und Vorarbeiten für die Verwaltung befreiter und besetzter Gebiete durch das Militär aber offenbar bereits im Herbst 1942 erwogen; die völlig ungeklärten Kompetenzen in diesem Bereich hatten dem jedoch zunächst im Wege gestanden; vgl. dazu NA, RG 226, E 59, b 1, Sitzungsprotokolle vom 23. und 24.10. 1942, sowie NA, RG 226, E 91, b 9, War Diary, R\&A-Branch, OSS London, Vol. 8: Civil Affairs, S. 10. Offenbar war in R\&A auch schon im Frühjahr 1943 ein Committee on Military Government gebildet worden, siehe NA, RG 226, E 1, b 1, f 19: Military Government. Katz behandelt den R\&A-Beitrag zum Civil Affairs-Programm nur relativ oberflächlich (vgl. Katz, Foreign Intelligence, S. 45-49, 70-77); sein Versuch, zwischen dem Beitrag der „Frankfurter Schule“ und dem der Meinecke-Schüler Holborn und Gilbert zu unterscheiden, dürfte nur bedingt sinnvoll sein, da Holborn zwar als Leiter bzw. Koordinator, nicht aber als Mitarbeiter bei der Formulierung der Guides fungierte, während Gilbert - der seit Februar 1944 für R\&A/London arbeitete - offenbar nur im Anfangsstadium an diesem Projekt mitarbeitete.

10 NA, RG 226, R\&A-History, Civil Affairs Guides, S.96f., und NA, RG 226, E 44, b 1, f: Listings of OSS-FEA Guides. 
Die Arbeit dieser Stellen für die CAD wurde von einem Editorial Committee geleitet, in dem die CAD den Vorsitz führte und in dem R\&A, FEA, State Department, Army, Navy und Vertreter derjenigen Behörden Mitglieder waren, die von dem jeweils diskutierten Guide betroffen waren. Angesichts des in der R\&A-History immer wieder beklagten „want of clarity as to what fundamental US policy toward Germany [...] was to be", scheint dieses Komitee als Vermittler oder Schiedsrichter bei Streitfragen allerdings häufig überfordert gewesen zu sein ${ }^{11}$. Auch Hajo Holborn, der dieses Projekt anfänglich so energisch und kompetent entworfen hatte, gelang es offenbar immer weniger, die zahlreichen Schwierigkeiten zu bewältigen ${ }^{12}$. Das wohl größte Problem - das völlige Fehlen von Richtlinien zur amerikanischen Besatzungspolitik war auf dieser Ebene freilich auch kaum zu lösen.

Da man in R\&A daran gewöhnt war, größere Projekte systematisch zu erarbeiten und Fragestellungen, Methoden und Ziele von Anfang an genau festzulegen, betrachtete man es als völlig unmöglich, die Arbeit an den geplanten Civil Affairs Guides in dem Vakuum aufzunehmen, das die von der Roosevelt-Administration praktizierte "policy of postponement" belassen hatte. Man begab sich deshalb nolens volens daran, in einer Reihe von abteilungsinternen Besprechungen Vorstellungen über Aufgaben, Funktionen und Ziele der amerikanischen Militärregierung in Deutschland zu entwickeln ${ }^{13}$. Die wichtigsten Punkte der dabei erarbeiteten „branch line“ sind in der R\&A-History folgendermaßen zusammengefaßt: „(1) Military government is a limited instrument which will during the wake of battle period be committed to bare operational functions; (2) in addition to these functions, during and after the wake of battle period military government should uproot and destroy all phases of Nazism and substitute anti-Nazi personnel for ousted Nazi officials; (3) after the wake of battle period its prime function would be the removal of obstacles to the emergence of democratic institutions; (4) military government should be of short duration in Germany."

Diese Vorstellungen zu Aufgaben und Funktionen der Militärregierung in Deutschland sind sicherlich geeignet, den in der R\&A-History erhobenen Anspruch, die Abteilung habe sich „realistically and perpetually“ bemüht, „to play down any possible mes-

11 NA, RG 226, R\&A-History, S. 97, 101; die hier scharf kritisierte passive Haltung der CAD mag allerdings auch auf die oben beschriebene, um politische Abstinenz bemühte Haltung des War Department zurückzuführen sein; vgl. in diesem Zusammenhang auch Holborns Bemerkungen über General Hilldring: American Planning, in: ders., Germany and Europe, S. 250.

12 Entsprechend kritische Bemerkungen in NA, RG 226, R\&A-History, Economic Subdivision, S.35.

${ }^{13}$ Dazu und zum Folgenden NA, RG 226, R\&A-History, Civil Affairs Guides, S. 98 f.; siehe auch NA, RG 226, E 1, b 1, f 8: „Proposed Outline for the Organization of Allied Military Government in Germany", [o.D., wahrscheinlich September 1943]; "Conditions of Military Government over Germany“, 22.9. 1943 (OSS, R\&A, Europe-Africa Division, Psychological Warfare Sub-Division, Central European Section); „Forms of Military Government over Germany“, 21.9. 1943 (OSS, R\&A); "What is the Purpose of Military Government over Germany?", 22.9. 1943 (OSS, R\&A, Europe-Africa Division, Psychological Warfare Sub-Division, Central European Section); „Military Occupation and International Control of Germany“, 22.9. 1943 (USSR Division, R\&A-Branch, OSS); „Will the Soviet Union Be Willing to Participate in a Joint Military Occupation and a Joint Military Government of Germany?“, 22.9. 1943 (USSR Division, R\&A-Branch, OSS); "United Nations Military Government over Germany", [o.D., wahrscheinlich ebenfalls September 1943]. 
sianic role for $\mathrm{MG}^{\star 14}$, berechtigt erscheinen zu lassen. Die Nüchternheit dieser Vorstellungen ist wohl besonders bemerkenswert, wenn man sich vor Augen hält, daß die in der Central Europe Section beschäftigten deutschen Emigranten an der Formulierung dieser Grundposition zweifellos beteiligt waren. Freilich ist der in der R\&A-History gewählte Begriff einer „branch line“ insofern irreführend, als er eine unabhängig formulierte R\&A-Position suggeriert. Wie aus einem nach Abschluß der Arbeiten an den Civil Affairs Guides verfaßten R\&A-Bericht hervorgeht, beruhten die von R\&A vertretenen Positionen jedoch auf den Richtlinien des Joint Army-Navy Manual of Military Government and Civil Affairs sowie des War Department Basic Field Manual of the Rules of Land Warfare und berücksichtigten zudem „policy declarations in statements of the American executive or in international declarations to which the US is a party "15. Insofern stell die R\&A „branch line“ also vor allem den Versuch eines Kompromisses zwischen den von verschiedenen Stellen vertretenen Konzeptionen dar, wobei in den Punkten (1) und (4) die Vorstellung des War Department von einer mit möglichst wenig politischen Aufgaben belasteten Militärrregierung zu erkennen ist, während sich hinter den Punkten (2) und (3) die vor allem vom State Department vertretene Konzeption verbergen dürfte, daß die Militärregierung in Deutschland Teil eines langfristigen Demokratisierungsprozesses sein sollte ${ }^{16}$. Wie im einzelnen noch darzulegen sein wird, fand man in R\&A aber auch noch in dieser Kompromißformel Raum für eigene Konzeptionen.

Diese R\&A „branch line“ wurde informell mit den für das Civil Affairs-Programm zuständigen Vertretern des Außenministeriums und der FEA abgesprochen. Während man sich im State Department anscheinend vorbehaltslos mit den in R\&A erarbeiteten Positionen einverstanden erklärte und diese später auch vertrat ${ }^{17}$, scheint sich die FEA zunächst darauf beschränkt zu haben, keine Ablehnung zu äußern. Im Laufe der Arbeit an den Führern sollte sich jedoch bald herausstellen, daß man in der FEA keineswegs mit R\&A übereinstimmte, sondern eigene Vorstellungen entwickelt hatte, die R\&A wiederum für nicht annehmbar hielt ${ }^{18}$.

Zunächst aber wurden die von R\&A vertretenen Positionen auch vom Editorial Committee gebilligt, das sich schließlich ebenfalls mit der Frage auseinandersetzen mußte, welche Ziele eine Militärregierung in Deutschland verfolgen sollte und welche Funktionen sie dabei ausüben müßte ${ }^{19}$. Als Ergebnis wurde General Hilldring der Entwurf einer 45 Seiten umfassenden Denkschrift vorgelegt, in der „Purpose, Objectives,

${ }^{14}$ NA, RG 226, R\&A-History, (Civil Affairs Guides), S. 99.

15 NA, RG 59, R\&A 2438, „The Civil Affairs Guide Program for Germany: An Analysis of its Principles and Aims“, 23.10. 1944; zum "Joint Army-Navy Manual of Military Government and Civil Affairs" (FM 27-5) vgl. Fainsod, Development of American Military Government Policy, in: Friedrich (u. a.), American Experiences in Military Government, S. $24 \mathrm{ff}$.

${ }^{16} \mathrm{Zu}$ den politischen Konzeptionen des State Department ausführlicher im 2. Teil dieses Kapitels.

17 Die Unterlagen in NA, RG 226, E 44 (Europe-Africa Division, Civil Affairs Guides) belegen, daß das State Department meist nur geringfügige Änderungen der von R\&A ausgearbeiteten Entwürfe verlangte. Siehe dazu auch die Darstellung des ehemaligen R\&A-Mitarbeiters Louis A. Wiesner: ders., Die organisierte Arbeiterbewegung, in Erd (Hrsg.), Reform und Resignation, S.172f.; vgl. auch Niethammer, Mitläuferfabrik, S. 59.

${ }^{18}$ NA, RG 226, R\&A-History, Civil Affairs Guides, S.98; zur Kontroverse zwischen R\&A und FEA ausführlicher im folgenden.

${ }^{19}$ Dazu und zum Folgenden NA, RG 226, E 44, b 1, f: Listings of OSS-FEA Guides. 
and Functions of a Military Government Program for Germany" umrissen wurden. Diese Denkschrift sollte, wie man hoffte, als Leitfaden bei der Ausarbeitung der Civil Affairs Guides und anderer, im Rahmen der Planungen für eine Militärregierung auszuarbeitender Papiere dienen und darüber hinaus, wie in einem Begleitschreiben an Hilldring angeregt wurde, durch die European Advisory Commission oder andere geeignete Kanäle der sowjetischen Regierung vorgelegt werden, um festzustellen, inwieweit Übereinstimmung in grundsätzlichen politischen Fragen bestehe. Als R\&A"Grundsatzpapier" zu den Aufgaben und Zielen eines militärischen Besatzungsregimes in Deutschland ist die General Hilldring vorgelegte Denkschrift - die die in R\&A entwickelte "branch line" deutlich widerspiegelt - von zentraler Bedeutung; sie verdient aber ebensoviel Beachtung mit Blick auf die spätere Umsetzung der amerikanischen Besatzungspolitik in Deutschland.

R\&A sah die Aufgaben einer Militärregierung im Spannungsfeld zwischen einer nach militärischen Gesichtspunkten streng begrenzten Auffassung - „bringing the war to a successful conclusion“ - und einem sehr viel politischeren Verständnis: „initiating the peace“. Da es ein vorrangiges Kriegsziel der Alliierten sei, das bestehende politische System Deutschlands zu zerstören, könne sich eine Militärregierung in Deutschland nicht auf die rein militärische Aufgabe einer erfolgreichen Beendigung des Krieges beschränken. Dieses traditionelle Verständnis der Aufgaben einer Militärregierung müsse deshalb - „under the pressure of events“ - erweitert werden. Dies bringe jedoch die Gefahr mit sich, daß eine Militärregierung zur Übernahme von Aufgaben gedrängt würde, die ihre begrenzten Möglichkeiten bei weitem überstiegen. Insbesondere bestehe die Gefahr, daß die Militärregierung davon ausgehen könnte, "that the period of military occupation provides a unique opportunity to create in Germany the conditions that will prevent it from again breaking the peace". Genau dies konnte eine Militärregierung nach Ansicht von R\&A aber nicht leisten; ebensowenig konnte sie ein demokratisches System in Deutschland installieren. Die für eine Demokratisierung notwendigen sozialen und politischen Reformen müßten vielmehr als Ergebnis des freien Agierens deutscher Kräfte zustande kommen und könnten von der Militärregierung nur angeregt bzw. erleichtert werden.

So wurde immer wieder gefordert, daß eine Militärregierung in Deutschland von möglichst kurzer Dauer sein und nur eng begrenzte Funktionen übernehmen solle. In diesem Zusammenhang wurde mehrfach der Besorgnis Ausdruck verliehen, daß die Militärregierung im Interesse einer möglichst reibungslosen Wiederherstellung von "law and order" versucht sein könnte, sich der „residual elements of the ruling classes" zu bedienen. Deren Entmachtung sei jedoch ein vorrangiges Kriegsziel, das nun einmal nicht ohne ein gewisses $\mathrm{Maß}$ an „disorder and pain“ zu erreichen sei: „[The] elimination of Nazism from Germany and from Europe is not a process that can be completed effectively without disorder and pain. Indigenous social forces must be allowed to operate and eventually to establish the kind of government in Germany that will be consistent with our peace aims. This can only be accomplished by the German people themselves, and we must not prejudice their chances by a misguided emphasis on achieving ends that can be attained only by strengthening the power of the traditional ruling groups."

Die hier referierten Passagen sind für das von R\&A entwickelte Verständnis der Aufgaben einer Militärregierung in Deutschland von zentraler Bedeutung. In ihnen 
scheint durch, daß die R\&A „branch line“ nicht nur den Versuch eines Kompromisses zwischen den von verschiedenen Regierungsstellen vertretenen Vorstellungen zur amerikanischen Besatzungspolitik darstellte, sondern auch ganz wesentlich von dem in R\&A-Analysen zum nationalsozialistischen Deutschland entwickelten Verständnis des deutschen Faschismus geprägt war ${ }^{20}$. Daß sich daraus nicht unproblematische Implikationen für die Definition der Aufgaben und Ziele einer Militärregierung in Deutschland ergaben, wird hier ebenfalls schon sichtbar.

So folgte aus den R\&A-Analysen zum nationalsozialistischen Deutschland, daß der deutsche Faschismus nicht ein dem deutschen "Nationalcharakter" eigentümliches Phänomen darstellte, das womöglich gar genetisch in der deutschen Psyche oder Mentalität verankert war, und daß ihm deshalb weder durch einen langen Umerziehungsprozeß und jahrelange Überwachung noch durch einen drastischen Straffrieden beizukommen war. Das Verständnis des Nationalsozialismus als Resultat struktureller Probleme, deren Wurzeln in der sozialen und wirtschaftlichen Verfassung Deutschlands zu suchen seien, legte als Lösung vielmehr eine tiefgreifende Demokratisierung gesellschaftlicher und wirtschaftlicher Strukturen nahe. Eine wirkliche Demokratisierung konnte aber kaum von einer Militärregierung dekretiert und autoritär durchgesetzt werden. Nach dem in den Deutschlandanalysen der Abteilung gezeichneten Bild war dies allerdings insofern gar nicht notwendig, als diese Studien immer wieder die Annahme implizierten, daß das von der Herrschaft der Nationalsozialisten befreite deutsche Volk bzw. die durch diese Herrschaft unterdrückten Bevölkerungsgruppen - also letztlich die Arbeiterschaft bzw. die Linke - auf die „soziale Revolution“ drängen würden, die in R\&A-Texten immer wieder als Vorbedingung für eine tiefgreifende Demokratisierung Deutschlands bezeichnet wird. Dementsprechend wird in einem Memorandum über "Conditions Affecting Military Occupation and Government of Germany", das dem General Hilldring vorgelegten Papier beigefügt ist ${ }^{21}$, ausgeführt: „[It] is also possible - even probable - that the end of the war will release political forces in Germany which, given time to develop and assume adequate organization forms, will be capable of accomplishing all or at any rate a large part of our basic objectives in Germany. If this case obtains, it is of utmost importance that military government should not stand in the way of the development of such political forces and forms. The fundamental problems of social reform will remain to be solved by the German people; the Allies cannot hope to impose a solution from above. If this is not recognized, military government may effectively prevent the very ends which it is intended to serve. The experience of this war has underlined the lesson of history that one nation cannot govern another, except for very limited ends and for short periods of time.

${ }^{20}$ Zum Einfluß zeitgenössischer Interpretationen des Nationalsozialismus auf Vorstellungen zur alliierten Deutschlandpolitk in der Nachkriegszeit siehe Dorn, Debate Over American Occupation Policy, in: PSQ 72/4 (1957), S.484f. Dorn faßt die gängigsten Interpretationen in drei verschiedenen „Schulen" zusammen und nennt dabei auch Franz Neumann als Vertreter der "neo-Marxist school of thought“. Diese Darstellung Dorns ist von Niethammer, Mitläuferfabrik, S.34ff. aufgegriffen und erweitert worden.

${ }^{21}$ In dem Hilldring vorgelegten Papier wird darauf hingewiesen, daß dieses Memorandum bereits "approval in the highest quarters" erhalten habe; ein frühere Version dieses Memorandums findet sich in NA, RG 226, E 1, f 8: „Proposed Outline for the Organization of Allied Military Government in Germany." 
The dangers of overstepping the legitimate limits and overestimating the real possibilities of Military Government should never be lost sight of."

Die von R\&A vertretenen Positionen konvergierten an dieser Stelle insofern mit den Interessen des War Department, als man dort schließlich in hohem Maße daran interessiert war, die Aufgaben und Verantwortungen einer Militärregierung in Deutschland unter weitgehender Ausklammerung politischer Fragen zu definieren und die amerikanische Militärregierung in Deutschland tatsächlich nur „for very limited ends and for short periods of time" zu konzipieren. Mit der Lösung grundlegender gesellschaftlicher Probleme wollte man im War Department keinesfalls belastet werden, und insofern konnte es den Militärs nur recht sein, wenn diese Probleme von den Deutschen selbst gelöst werden sollten, insbesondere dann, wenn diese sich tatsächlich als willige Vollstrekker amerikanischer bzw. alliierter „peace aims" erweisen würden. Dennoch mußte diese Vorstellung letztlich graue Theorie bleiben: Die Empfehlung, daß die Militärregierung "disorder and pain" in Kauf nehmen solle, um abzuwarten, ob bestimmte gesellschaftliche Gruppen in Deutschland tatsächlich in der Lage (und willens) sein würden, die wichtigsten Ziele amerikanischer Politik in Deutschland zu verwirklichen, stand in krassem Gegensatz zu den vom War Department unter dem Gesichtspunkt von „military necessity" definierten Aufgaben und Verantwortungen der amerikanischen Militärregierung.

R\&A hatte sich mit diesen Überlegungen zu Aufgaben und Funktionen der amerikanischen Militärregierung jedoch zunächst einmal die Grundlage für das Arbeitsprogramm für die Civil Affairs Guides geschaffen, mit dessen Entwicklung Hajo Holborn beauftragt worden war. Wie bereits erwähnt, sah dieses Programm zunächst 80 Guides für Deutschland vor. Für jeden Führer wurden die in dem jeweiligen Bereich anzustrebenden Ziele und die sich aus diesen Zielsetzungen für die Militärregierung ergebenden militärischen, wirtschaftlichen, politischen und sozialen Aufgaben säuberlich aufgelistet. Doch obwohl dieses Programm - und damit auch die ihm zugrundeliegenden Positionen zu den Aufgaben einer Militärregierung in Deutschland - vom Editorial Committee gebilligt worden war, wurde bald deutlich, daß zwischen den mit diesem Projekt befaßten Behörden keineswegs Einigkeit in all diesen Punkten bestand. Vor allem zwischen R\&A und FEA kam es immer wieder zu hitzigen Debatten über einzelne Führer. Während R\&A nach eigenem Bekunden beständig bestrebt war, „to play down any possible messianic role for MG", schien die FEA nach dem Eindruck von R\&A nicht einsehen zu wollen, daß die Militärregierung nur schr begrenzte Aufgaben übernehmen konnte, denn, wie R\&A kritisierte: „in some of their recommendations they ascribed functions to the 5,000 or so MGO's that were not being carried out in the United States by ten times that number of American federal officials." Anders als R\&A wollte sich die FEA auch nicht damit zufriedengeben, daß die amerikanische Militärregierung nur „a purcly negative function with respect to a future Germany“ ausüben konnte, sondern schien vielmehr den Ehrgeiz zu haben, Deutschland mit Hilfe der Militärregierung zu einer "fair replica of the New Deal“ umzuformen ${ }^{22}$.

Viele der auszuarbeitenden Führer wurden so unvermeidlich zu "battle grounds for the rationalization of these divergent positions". Dabei waren es nicht selten scheinbar triviale Fragen, an denen sich hitzige Kontroversen entzündeten. So entbrannte bei-

22 NA, RG 226, R\&A-History, Civil Affairs Guides, S. 100. 
spielsweise ein erbitterter Disput über die Frage, ob die deutsche Textilindustrie synthetische Fasern produzieren sollte. Der eigentliche Streitpunkt ergab sich daraus, daß für die Herstellung synthetischer Fasern Kohle benötigt wurde, die aber, wie vorauszusehen war, überaus knapp sein würde. R\&A vertrat die Ansicht, daß die Herstellung synthetischer Fasern dennoch nicht von vornherein untersagt werden sollte, da es im Interesse der Militärregierung sei, daß Deutschland seinen Textilbedarf soweit wie möglich aus eigenen Ressourcen und eigener Produktion deckte. Diese Position wurde von der FEA jedoch auf das heftigste kritisiert. Während die FEA ihre Ablehnung damit begründete, daß keine Kohle für die Herstellung synthetischer Fasern abgestellt werden sollte, glaubte man in R\&A schließlich erkennen zu können, daß die FEA nur ihren „trust-busting anti-cartel point of view" verbergen wolle und in Wirklichkeit fürchtete, "[that] any promotion of synthetics was bound to benefit the great malignant octopus I. G. Farben “23.

Angesichts der in den R\&A-Deutschlandanalysen enthaltenen, Neumann'schem Denken verpflichteten scharfen Kritik an der Macht der deutschen „Monopolisten“ mag es befremdlich erscheinen, daß man in R\&A den von der FEA eingenommenen „trust-busting anti-cartel point of view“ nun nicht teilte. Für R\&A hatte in diesem Punkt jedoch offenbar der Grundsatz Priorität, daß es die amerikanische Militärregierung in Deutschland aus pragmatischen wie politischen Gründen nicht auf sich nehmen könne, tiefgreifende strukturelle Veränderungen durchzuführen, und so hatte nach Ansicht von R\&A auch für die Politik der Militärregierung gegenüber den deutschen Kartellen grundsätzlich zu gelten: „Basic changes and long-range reform of Germany's economic structure must be ruled out as the job of AMG and left to the German people themselves acting through a new Government. "24 Dementsprechend vertrat R\&A die Position, daß die Militärregierung nicht die komplexe Aufgabe übernehmen könne, die Kartelle aufzulösen, sondern daß sie sie lediglich einer gründlichen Entnazifizierung unterziehen könne und danach sicherzustellen habe, daß das Wirtschaftsgebaren der Kartelle nicht den wirtschaftspolitischen Zielen der Militärregierung zuwiderlaufen konnte.

Freilich war man in R\&A nicht überrascht, daß diese Vorstellungen weder in der FEA noch in anderen Behörden Unterstützung fanden. Selbst im War Department, wo man es im allgemeinen zu schätzen wußte, daß R\&A die amerikanische Militärregierung in Deutschland so wenig wie möglich mit politischen Aufgaben belasten wollte, lehnte man die von R\&A vertretene Position diesmal mit dem Argument ab, "that the break-up of cartels would be advantageous both actually and [...] symbolically" 25 .

${ }^{23}$ NA, RG 226, R\&A-History, Civil Affairs Guides, S.100; NA, RG 59, R\&A 1950.1, War Department Pamphlet No. 31-139, Civil Affairs Information Guide, "Textile Production and Distribution in Germany“, 5.10. 1944. Zum Bild des "great malignant octopus I. G. Farben“ vgl. Morgenthau, Jr., Germany Is Our Problem, S. 38.

${ }^{24}$ Dazu und zum Folgenden NA, RG 59, R\&A 1904.C., (Preliminary Draft), "Cartels and Cartel-Like Organizations in Germany", 15.2. 1944; NA, RG 59, R\&A 1904.1, (Draft), Civil Affairs Guide, "US Policy Toward German Cartels and Cartel-Like Organizations During Allied Occupation“, 20.10. 1944; zur Kontroverse um diese Entwürfe siehe NA, RG 226, E 44, b 4, f IV, General: B. Institutional Evaluation. Aus diesen Papieren geht hervor, daß die Entwürfe von Isaiah Frank ausgearbeitet wurden, anfänglich offenbar unter Beteiligung von Moses Abramovitz.

${ }^{25}$ NA, RG 226, E 44, b 1, f: Editorial Committee Clearance, Schreiben vom 20.5. 1944 an Holborn von War Department, School of Military Government. 
Doch R\&A zog nicht nur mit der Empfehlung, die Kartelle weiterbestehen zu lassen, Kritik auf sich. Äußerst kontrovers war auch die Frage, wie eine gründliche Entnazifizierung der Kartelle aussehen sollte. In R\&A verstand man darunter zunächst einmal eine strukturelle Entnazifizierung, d. h. die Eliminierung aller Kontrollen und Organisationsformen, mit deren Hilfe das NS-Regime die Kartelle in die Kriegswirtschaft integriert hatte. Diese Maßnahmen sollten von einer personellen Entnazifizierung ergänzt werden, die die Entlassung und dauerhafte Ausschaltung direkter oder indirekter Einflußnahmen „aktiver“ Nazis umfassen sollte. Nach Ansicht von R\&A konnte diese personelle Entnazifizierung der Kartelle durch die strikte Durchführung der allgemeinen Entnazifizierung gewährleistet werden, da die von der Abteilung dafür entwickelte Konzeption bereits darauf abzielte, alle durch ihre Verbindungen zu nationalsozialistischen Organisationen oder durch ihre Stellung als "active Nazis“ kompromittierten Personen aus ihren Positionen zu entfernen.

Den entsprechenden Richtlinien in dem von R\&A ausgearbeiteten Führer zur

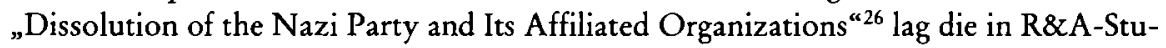
dien immer wieder vertretene, Neumanns Behemoth folgende Interpretation zugrunde, daß das NS-Regime von einer aus den Spitzen von Partei, Wirtschaft, Bürokratie und Militär zusammengesetzten Herrschaftselite getragen wurde, die es zu eliminieren gelte. Die diesen Gruppen zuzurechnenden Nazifunktionäre sollten von den Besatzungstruppen sofort erfaßt und verhaftet werden; ihre Zahl schätzte man in R\&A auf etwa $222000^{27}$. Diese Schätzung beruhte auf einer nach Ämtern bzw. Funktionen geordneten Liste, durch die, wie ausdrücklich betont wurde, viele Funktionäre mehrfach erfaßt seien, während andererseits viele der "aktivsten“ Nazis durch diese Kategorien überhaupt nicht erfaßt würden. Einige Anhaltspunkte für deren Identifizierung wurden zwar in einem gesonderten Kapitel skizziert, doch letztlich wurde an den politischen Instinkt der verantwortlichen Offiziere appelliert, die einerseits auf die Mithilfe der lokalen Bevölkerung verwiesen wurden, andererseits aber mehrfach gewarnt wurden, entsprechenden Informationen unkritisch Glauben zu schenken.

Für die Entnazifizierung der Kartelle wollte sich die FEA jedoch nicht mit der von R\&A befürworteten strengen Durchführung der allgemeinen Entnazifizierungsbestimmungen zufriedengeben und forderte die grundsätzliche Entlassung aller Inhaber leitender Positionen. In einem FEA-Entwurf für Richtlinien zur „Elimination of Nazi and Pro-Nazi Personnel from the German Banking Structure" wurde ausdrücklich ge-

${ }^{26}$ NA, RG 59, R\&A 1655.5, War Department Pamphlet No. 31-110, Civil Affairs Guide, „Dissolution of the Nazi Party and Its Affiliated Organizations“, 22.7. 1944; Verfasser dieser Richtlinien war Marcuse, vgl. NA, RG 226, E 44, b 1, f: Division Review Committee Meeting, und b 2, $\mathrm{f}$ : Status of reports. In deutscher Übertragung ist dieser Führer sowie der ihm beigefügte, ebenfalls von Marcuse ausgearbeitete Anhang (NA, RG 59, R\&A 1655.5A, - Supplement: „De-Nazification of Important Business Concerns in Germany“, 27.11. 1944) auszugsweise abgedruckt in Söllner (Hrsg.), Archäologie der Demokratie, Bd.1, S.157-172.

27 Siehe dazu Gilbert, Lehrjahre im alten Europa, S.199, und vgl. JCS vom 22.9. 44 in FRUS: Malta and Yalta, S. 143-154, sowie die revidierte Fassung vom 6.1. 1945 in FRUS 1945/III, S. $378 \mathrm{ff}$., besonders $381 \mathrm{ff}$. mit JCS 1067 vom April 1945, abgedruckt in: Documents on Germany under Occupation 1945-1954, S.13ff. Die gegenüber der ursprünglichen Fassung vorgenommenen Einschränkungen sind nur bedingt im Sinne der von R\&A vertretenen Positionen. Die amerikanischen Planungen für die Entnazifizierung sind detailliert dargestellt bei Niethammer, Mitläuferfabrik, S. 52 ff. 
warnt: „Absence of conspicuous ties to the Nazi party does not [...] mean that the present holders of leading positions in the German banking structure are not, real' $\mathrm{Na}$ zis. ${ }^{28}$ Dieses Problem hatte man freilich auch in R\&A keineswegs übersehen und hatte eben deshalb der „Identification of ,Active Nazis" Other Than Those Identified by Their Official Position“ in den Richtlinien zur Auflösung der NSDAP ein gesondertes Kapitel gewidmet, auch wenn die in diesem Zusammenhang gegebenen Anhaltspunkte, wie bereits erwähnt, eher vage blieben.

Die zwischen R\&A und FEA ausgetragene Kontroverse um die personelle Entnazifizierung der deutschen Industrie und Wirtschaft mag auf den ersten Blick eher als ein Streit um Formulierungen erscheinen, zumal R\&A im Grunde ganz ähnlich wie die FEA argumentierte. In einem R\&A-Entwurf zu „Principles for the De-Nazification of Non-Government and Non-Party Organizations" wurde beispielsweise ebenfalls vorgeschlagen, die Inhaber aller leitenden Positionen in Industrie und Wirtschaft zunächst zu entlassen; falls sie den Nachweis erbrachten, daß sie keine Nazis seien, könnten sie später wieder in ihr Amt eingesetzt werden ${ }^{29}$. Auch die von Herbert Marcuse ausgearbeiteten Richtlinien zur „De-Nazification of Important Business Concerns in Germany“, die als Anhang dem Civil Affairs Guide zur „Dissolution of the Nazi Party and Its Affiliated Organizations" beigefügt waren, sahen praktisch die Festnahme und Entlassung aller führenden Persönlichkeiten des Wirtschaftslebens vor ${ }^{30}$.

Doch trotz dieser vordergründigen Übereinstimmung von FEA- und R\&A-Empfehlungen in diesem Punkt bestanden im Verständnis von R\&A grundsätzliche Unterschiede in der mit ihnen verbundenen Zielsetzung. Deutlicher faßbar werden diese unterschiedlichen Zielvorstellungen in einer hitzigen Kontroverse, die um die von R\&A entworfenen Richtlinien zur "Abrogation of Nazi Laws“ und dem damit konkurrierenden FEA-Entwurf zur „Elimination of Nazi Political Laws“ entbrannte. Bei der Diskussion um diese Entwürfe warf Franz Neumann der FEA vor, daß sie sich zu sehr auf ideologische Probleme konzentriere; vernachlässigt wurden dabei nach Ansicht von Neumann "the real social, political, and economic problems which National

${ }^{28}$ NA, RG 226, E 44, b 3, II, „Elimination of Nazi and Pro-Nazi Personnel from the German Banking Structure“, Foreign Economic Administration, Economic Institutions Staff.

${ }^{29}$ NA, RG 226, E 44, b 3, „Principles for the De-Nazification of Non-Government and NonParty Organizations" (R\&A 1655.5 a), 8. 8. 1944; die diesen Vorschlag rechtfertigende Bemerkung - "the burden of proof may justly be imposed upon them to clear themselves of the presumption of complicity " war allerdings bezeichnenderweise am Rand mit einem Fragezeichen versehen, wurde jedoch letztlich beibehalten (vgl. dazu NA, RG 59, R\&A 1655.5A, "Dissolution of the Nazi Party and Its Affiliated Organizations“ - Supplement: „De-Nazification of Important Business Concerns in Germany “, 27.11. 1944). Offenbar war Marcuse auch der Verfasser dieses Entwurfs, vgl. dazu nächste Fußnote.

${ }^{30}$ NA, RG 59, R\&A 1655.5A, "Dissolution of the Nazi Party and Its Affiliated Organizations" Supplement: „De-Nazification of Important Business Concerns in Germany“, 27.11. 1944 (mit einer etwa 1800 Namen umfassenden Liste führender deutscher Industrieller); vgl. auch die entsprechenden Unterlagen in NA, RG 226, E 44, b 3, insbesondere den ebenfalls von Marcuse ausgearbeiteten Entwurf: "Some Criteria for the Identification of Anti-Nazis in Germany. A political and social analysis“, 13.6. 1944; [später als R\&A 2189 - mit gleichlautendem Titel vom 15.11. 1944]. Die Autorenschaft Marcuses für alle diese Arbeiten geht hervor aus NA, RG 226, E 44, b 1, f: Division Review Committee Meeting, und b 2, f: Status of reports. Aus den R\&A-Unterlagen ist allerdings nicht ersichtlich, ob der Nachtrag vom 27.11. 1944 später auch tatsächlich in den offiziellen Führer des War Department aufgenommen wurde. 
Socialism has created“. Wie Neumann ausführte, war R\&A dagegen „not concerned so much with eradicating Nazi ideology, but rather the Nazi system ${ }^{\alpha 31}$.

Tatsächlich benannte Neumann hier den qualitativen Unterschied, der - von den im doppelten Sinne des Wortes „abgeklärten“ Kompromißformeln der offiziellen Textversionen verdeckt - zwischen den von R\&A vertretenen deutschlandpolitischen Vorstellungen und den Demokratisierungskonzeptionen der meisten anderen Washingtoner Regierungsstellen bestand ${ }^{32}$. Zwar wollten alle die Vernichtung des Nationalsozialismus als vorrangiges Kriegsziel verwirklicht sehen, doch zeichnete sich $a b$, daß darunter primär die Vernichtung des „dominant Nazi imprint “33, also einer Art von „NSÜberbau“ verstanden werden würde. Den von R\&A vertretenen Positionen lag dagegen das Neumanns Behemoth verpflichtete Verständnis zugrunde, "[that National Socialism is] but one form - though the most vicious one, - which the imperialist forces have assumed for the execution of their program" und daß seine dauerhafte Ausschaltung deshalb nur durch tiefgreifende gesellschaftliche Veränderungen gewährleistet werden könne ${ }^{34}$.

Die bereits angedeutete Unvereinbarkeit des von R\&A entwickelten Verständnisses der Aufgaben und Funktionen einer Militärregierung in Deutschland und der vom War Department vorgegebenen Priorität von "law and order" wird hier einmal mehr greifbar. Denn während sich die Entfernung des „dominant Nazi imprint“ mit dieser Priorität durchaus vereinbaren ließ, würden die von R\&A für notwendig gehaltenen grundlegenden gesellschaftlichen Veränderungen eben kaum ohne "disorder and pain“ abgehen. Vordergründig war diese fundamentale Inkongruenz dadurch verdeckt, daß auch R\&A immer wieder für eine sehr restriktiv verstandene, primär an pragmatischen Überlegungen orientierte und scheinbar unpolitische Rolle der Militärregierung eintrat. Doch während man damit im War Department tatsächlich die Vorstellung einer von langfristigen politischen Überlegungen möglichst unbehinderten, vorrangig an militärischen Notwendigkeiten orientierten Rolle der Militärregierung verband, knüpfte man in R\&A ganz bestimmte politische Erwartungen und Hoffnungen an diese "unpolitische“ Rolle der amerikanischen Militärregierung. Denn selbst wenn die R\&A-History die über rein operative Funktionen hinausgehenden Aufgaben einer Mi-

${ }^{31}$ NA, RG 226, E 44, b 3, f: I. A. Fundamental Nazi Political Laws; R\&A mußte in dieser Kontroverse eine Niederlage hinnehmen: der R\&A-Entwurf wurde scharf kritisiert und schließlich zugunsten des FEA-Entwurfs abgelehnt, vgl. ebenda, f: May 3 Meeting State Dept. Die FEA kritisierte ihrerseits an den von R\&A ausgearbeiteten Richtlinien zum "Problem of German Youth Under Military Government “ (NA, RG 59, R\&cA 1655.19, War Department Pamphlet No. 31-182, 29.7. 1944) das Fehlen jeglicher „reference to the need for ideological reorientation and guidance" und die Vernachlässigung der nach Ansicht der FEA notwendigen "de- $\mathrm{Na}_{2}$ zification of the minds of the young"; in: NA, RG 226, E 44, b 4, FEA-Schreiben vom 1.7. 1944. Vor dem Hintergrund des von R\&A vertretenen Verständnisses der Aufgaben und Möglichkeiten einer Militärregierung war es freilich nur konsequent, daß R\&A keinerlei Konzeptionen für eine „Umerziehung“ entwickelte.

32 Vgl. dazu Friedrich, Military Government and Democratization, in: ders. (u. a.), American Experiences in Military Government, S.3-22.

33 So die Formulierung in dem FEA-Entwurf für den Civil Affairs Guide "Elimination of Nazi and Pro-Nazi Personnel from the German Banking Structure“, in NA, RG 226, E 44, b 3.

${ }^{34}$ NA, RG 226, E 1, b 1, f 8, "What is the Purpose of Military Government Over Germany?", 22.9. 1943 (OSS/R\&A: Europe-Africa Division - Psychological Warfare Subdivision, Central Europe Section). 
litärregierung in dürren Worten zusammenfassen konnte - „military government should uproot and destroy all phases of Nazism and substitute anti-Nazi personnel for ousted Nazi officials; [. . ] after the wake of battle period its prime function would be the removal of obstacles to the emergence of democratic institutions " 35 -, so verbargen sich dahinter doch wieder dieselben politischen Konzeptionen, die auch den R\&AAnalysen des nationalsozialistischen Deutschlands zugrunde lagen.

Was man unter „obstacles to the emergence of democratic institutions “ $\mathrm{zu}$ verstehen hatte, war beispielsweise in einem R\&A-Arbeitspapier zum „Purpose of Military Government " 36 deutlich ausgesprochen: "the Nazi Party; the military caste; the Junker caste; the industrial monopolies“. Ähnlich wie in den Analysen zu Grundlagen und Herrschaftsmechanismen des nationalsozialistischen Regimes - besonders der Arbeit zur „Relation Between Aggression and Business Structure in Germany “37 - bezeichnete R\&A auch hier wieder die "destruction of the present concentration of socio-economic power" in Deutschland als Grundbedingung für einen dauerhaften Frieden. R\&A wies in diesem Zusammenhang erneut darauf hin, daß es in einflußreichen Kreisen Stimmen gab, die dafür plädierten, diese Grundbedingung ganz einfach durch die physische Zerstörung der deutschen Industrie zu schaffen. Wiederum wurde ein solches Vorgehen abgelehnt, weil es eine Erschütterung des wirtschaftlichen und sozialen Gefüges ganz Europas nach sich ziehen würde, und in R\&A hielt man dies schlichtweg für "not only immoral but actually socially and economically impossible“.

Die einzig sinnvolle Alternative dazu lag nach Ansicht der Abteilung in „profound social transformations which break the power of those groups responsible for Germany's aggressionist policies“. Dies war jedoch wiederum etwas, was nicht von einer Militärregierung geleistet werden konnte, sondern, wie R\&A betonte, einzig und allein von denjenigen Gruppen in Deutschland, "who are opposed to the policies of imperial aggrandizement“. Die Militärregierung könne die Bestrebungen dieser „democratic groups“ allerdings erheblich erleichtern "by encouraging them, cooperating with them and avoiding material and ideological support of the Nazis, military leaders, Junkers, industrialists and the high civil servants", die als die "traditional reactionary forces in Germany“ anzusehen seien. Abschließend wurde nochmals ausdrücklich die Duldung und sogar die aktive Unterstützung derjenigen Gruppen empfohlen, „that desire to carry out fundamental socio-economic changes (such as division of Junker estates, nationalization of monopolies and banks)“.

Derartige Empfehlungen lassen kaum Zweifel daran, daß die von R\&A im Hinblick auf die Rolle der Militärregierung immer wieder befürwortete „purely negative function with respect to a future Germany“ in Wirklichkeit nicht ganz so "negativ“ gemeint war. Während manche der für die CAD ausgearbeiteten Führer eine nicht ganz so deurliche Sprache sprechen, hielt R\&A an diesen Positionen grundsätzlich doch fest. So wurde - ähnlich wie schon in dem General Hilldring vorgelegten Memorandum - in dem von Marcuse ausgearbeiteten Führer zur „Dissolution of the Nazi Party and Its Affiliated Organizations“ in kaum zu übersehender Umkehrung der vom War

${ }^{35}$ Siehe die oben bereits zitierte Zusammenfassung der R\&A „branch line“ (Anmerkung 13).

${ }^{36}$ NA, RG 226, E 1, b 1, f 8, "What Is the Purpose of Military Government Over Germany?", 22.9. 1943.

37 NA, RG 59, R\&A 1145, 25.8. 1943, vgl. Kapitel IV., 2. Teil. 
Department vorgegebenen Prioritäten ausgeführt, daß die im Interesse der Militärregierung liegende Aufrechterhaltung bzw. Wiederherstellung von „law and order" nur nach der Vernichtung des Nazismus möglich sei. Im Interesse der Sicherheit der Besatzungsstreitkräfte sowie der Wiederherstellung von "law and order" sei es deshalb angeraten, "[to show] leniency towards the spontaneous acts of the anti-Nazi opposition, and [.. .] harshness towards all Nazi elements". In ähnlicher Weise wurde in dem ebenfalls von Marcuse ausgearbeiteten Guide zur „Policy Toward Revival of Old Parties and Establishment of New Parties in Germany" empfohlen, daß Kommunisten, die Sabotageakte gegen von Nazis geleitete Firmen begingen, weniger streng bestraft werden sollten als Nazis, die Sabotageakte verübten. Diese Empfehlung wurde beibehalten, obwohl ein Vertreter der School of Military Government kritisiert hatte, daß es durchaus genüge, die Ausschaltung von Nationalsozialisten zum erklärten Ziel amerikanischer Politik zu machen, zumal die bevorzugte Behandlung bestimmter Gruppen durch die Militärregierung das Prinzip der Gleichheit verletze und überdies geeignet sei, diese Gruppen durch eine eventuelle Identifizierung mit der Besatzungsmacht zu diskreditieren $^{38}$.

Während sich R\&A von diesem Einwand hier nicht beeindrucken ließ, nahm die Abteilung eben diese Argumentation in Entwürfen zu einem Civil Affairs Guide über „Military Government and Problems with Respect to the Jews of Germany“39 auf. Dort wurde der Militärregierung nämlich empfohlen, den Eindruck zu vermeiden, "that the Jews are to be singled out for special treatment [.. .] Jews should receive the same treatment as other groups persecuted by the Nazis [.. .] Assistance should be based on need rather than preference. " $Z$ war wurde eingeräumt, daß Juden aufgrund des Ausmaßes der von ihnen erlittenen Verfolgung zweifellos zu den Bedürftigsten gehörten und daß eine Militärregierung darauf vorbereitet sein müsse, sofortige Hilfsmaßnahmen zu leisten. Im Hinblick auf diese Hilfsmaßnahmen wurde jedoch nochmals betont: "In the distribution of food, as well as other forms of relief, Jews should be treated in the same way as other German citizens in need of special rations. Preferential treatment for Jews as such should be avoided. " 40 Während diese Empfehlungen

${ }^{38}$ NA, RG 59, R\&A 1655.1, War Department Pamphlet No. 31-116, Civil Affairs Guide, „Policy Toward Revival of Old Parties and Establishment of New Parties in Germany", 22.7. 1944; die Autorenschaft Marcuses geht hervor aus NA, RG 226, E 44, b 2, f: Status of reports. Die Kritik der School of Military Government findet sich in NA, RG 226, E 44, b 1, f: Editorial Committee Clearance, weitere Unterlagen in $b 3$. In deutscher Übertragung ist dieser Führer abgedruckt in Söllner, Archäologie der Demokratie, Bd.1, S.207-224. Niethammer, Mitläuferfabrik, S.59, Anmerkung 102, listet diesen Führer ebenfalls auf, gibt allerdings in Klammern "State Dep. Off. of Int. Res." an, offenbar um dessen (Mit-)Autorenschaft zu kennzeichnen.

39 NA, RG 59, R\&A 1655.23 (Part I/II/III), Civil Affairs Guide (Draft), „Allied Military Government and the Jewish Problem“, 29.4. 1944 (und überarbeitete Versionen ((II und III)) vom 14.6. und 10.7. 1944); sowie die Unterlagen in NA, RG 226, E 44, b 2 und 4, wo als Verfasser dieser Entwürfe Sharp genannt wird. Obwohl aus den R\&A-Unterlagen nicht hervorgeht, daß einer dieser Entwürfe als endgültige Version für einen Civil Affairs Guide angenommen wurde, war dies offenbar doch der Fall, vgl. Wiener Library, Tel Aviv, War Department Pamphlet No. 31121, Civil Affairs Guide, „Military Government and Problems with Respect to the Jews in Germany", 22.7. 1944.

$40 \mathrm{Vgl}$. zu diesen R\&A-Empfehlungen jedoch Katz, Foreign Intelligence, S.72, wo ohne eingehendere Ausführungen behauptet wird, R\&A sei dafür eingetreten, "that social provisions be made for the problems of Jews in postwar Europe as among other religious groups". 
damit begründet wurden, daß eine bevorzugte Behandlung von Juden durch die Militärregierung geeignet sei, "to perpetuate the distinctions of Nazi racial theory“, scheint sich in ihnen doch auch der in R\&A-Studien immer wieder vertretene Standpunkt fortzusetzen, daß sich der nationalsozialistische Antisemitismus qualitativ nicht von anderen Terrormaßnahmen des NS-Regimes unterscheide. Für die in diesem Führer angesprochenen humanitären Maßnahmen folgte daraus nur die schließlich durchaus gerechtfertigte Gleichbehandlung aller Opfer nationalsozialistischer Verfolgung, doch hatte diese Haltung eben auch subtile politische Implikationen, wenn es um die künftige Rolle derer ging, die wegen ihrer politischen Aktivitäten zu Opfern der nationalsozialistischen Verfolgung geworden waren.

Die von der School of Military Government während der oben angesprochenen Kontroverse vertretene Ansicht, daß es geraten erscheine, allen deutschen Parteien zu mißtrauen und sie deshalb alle zu überwachen, fand so nur bedingt Widerhall in den von R\&A formulierten Richtlinien. Die Notwendigkeit sorgfältiger Überwachung und Kontrolle durch die Militärregierung sah R\&A eigentlich nur im Falle von nationalistischen rechten Parteien und Organisationen gegeben ${ }^{41}$. Zwar trat R\&A nirgendwo für eine Bevorzugung bestimmter politischer Parteien ein, hielt aber gleichzeitig hartnäckig an dem Argument fest, daß es im wohlverstandenen Interesse der Militärregierung sei, „demokratische“, nämlich tiefgreifende Reformen anstrebende Kräfte zu fördern ${ }^{42}$. Zudem implizierte schon allein die von R\&A vertretene Entnazifizierungskonzeption die Bevorzugung bestimmter gesellschaftlicher Gruppen. Zum einen waren die Kriterien, nach denen die Entnazifizierung durchgeführt werden sollte, mit ihrer angestrebten Eliminierung der Herrschaftseliten ganz wesentlich darauf abgestellt, der sozialen Revolution, die nach Ansicht von R\&A notwendige Vorbedingung einer echten Demokratisierung der deutschen Gesellschaft war, den Boden zu bereiten. Zum anderen sollte nach der von R\&A vertretenen Konzeption im Zuge der Entnazifizierung aber auch die Etablierung einer demokratischen "Gegenelite“ begünstigt werden, die, wo immer möglich, aus den Reihen des Widerstands rekrutiert werden soll$\mathrm{te}^{43}$. In diesem Zusammenhang kam die in R\&A-Analysen zum nationalsozialistischen Deutschland entwickelte Vorstellung zum Tragen, daß die deutsche Arbeiterschaft keineswegs völlig nazifiziert sei, sondern sich vielmehr einen grundsätzlich demokratischen Geist bewahrt habe. Ähnlich wie in den R\&A-Studien zum deutschen Widerstand, in denen eine sozialistischen Idealen verpflichtete Arbeiterschaft als Garant und Hoffnungsträger für das Weiterbestehen eines „anderen Deutschland “ erschienen war, gingen die in Vorbereitung der amerikanischen Besatzungspolitik ausgearbeiteten

${ }^{41}$ NA, RG 59, R\&A 1655.1., War Department Pamphlet No. 31-166, Civil Affairs Guide, „Policy Toward Revival of Old Parties and Establishment of New Parties in Germany", 22.7. 1944.

42 Sehr explizit ist in dieser Hinsicht die nach Abschluß des Civil Affairs-Programms entstandene (und deshalb nicht den offiziellen War Department-Papieren zuzurechnende!) R\&A-Arbeit "The Revival of German Political and Constitutional Life Under Military Government * vom 18.9. 1944 (NA, RG 59, R\&A 2076). In einer unzulänglichen, weil einige wichtige Punkte unzutreffend wiedergebenden Übersetzung ist diese Arbeit abgedruckt in Söllner (Hrsg.), Archäologie der Demokratie, Bd.1, S.225-254.

43 Wie in NA, RG 59, R\&A 2076, ,The Revival of German Political and Constitutional Life Under Military Government“, 18.9. 1944, betont wird: „even if they do not possess adequate administrative experience." 
R\&A-Papiere nun davon aus, daß sich die wiederbegründeten Gewerkschaften als treibende Kraft einer tiefgreifenden Demokratisierung der deutschen Gesellschaft und damit auch als Hilfe für die Besatzungstruppen erweisen würden. Dementsprechend empfahl Neumann als Verfasser des Civil Affairs Guide „Labor Relations and Military Government", daß die Militärregierung den wiederbegründeten Gewerkschaften möglichst viel Freiheit gewähren sollte: „The trade unions should have the right of free assembly, speech, and press, and free access to the radio and broadcasting on a nondiscriminatory basis provided only that such assembly, speech or writing does not interfere with military necessity or public security. ${ }^{* 44}$

Manche der in diesem Führer vertretenen Positionen mögen allerdings ähnlich zurückhaltend erscheinen wie die R\&A-Empfehlungen zur Politik gegenüber den deutschen Kartellen. In der Diskussion um diesen Führer kritisierte die FEA, daß die Formulierungen des R\&A-Entwurfes dazu tendierten, "to emphasize apparent military security at the cost of growth of democratic organizations and long-run military security“, und bemängelte beispielsweise, daß R\&A der Arbeiterschaft zunächst nur die „Erlaubnis “ und nicht, wie die FEA forderte, das „Recht“, sich zu organisieren, geben wollte ${ }^{45}$. Auffallend ist zudem, daß der Führer davon ausgeht, daß die wiederbegründeten Gewerkschaften auf Weimarer Strukturen zurückgreifen würden. Diese „konser-

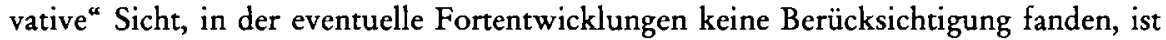
den von einem Teil der R\&A-Mitarbeiter angeblich gehegten Befürchtungen zugeschrieben worden, „daß der durchschnittliche Offizier der Militärregierung noch nicht einmal dieses erlauben würde, geschweige denn, daß sie die Einsicht hätten, eine vernünftige fortschrittliche Veränderung anzuleiten oder zu gestatten"46. Der Rückgriff bzw. das Anknüpfen an institutionelle oder organisatorische Formen der Weimarer Republik wird allerdings auch in einigen anderen Civil Affairs Guides empfohlen, und es ist anzunehmen, daß derartige Empfehlungen durch mehrere Überlegungen motiviert waren. Vor allem dürfte die Annahme eine Rolle gespielt haben, daß das Anknüpfen an bekannte Strukturen angesichts des zu erwartenden Chaos in der unmittelbaren Nachkriegszeit gewisse pragmatische Vorteile haben und in akzeptablen vorläufigen Organisationsformen resultieren würde, ohne spätere Reformen auszuschließen ${ }^{47}$.

44 NA, RG 59, R\&A 1655.28, War Department Pamphlet No. 31-159, Civil Affairs Guide, „Labor Relations and Military Government" ${ }^{\text {" }}$ 22.7. 1944. Unterlagen in NA, RG 226, E 44, b 1, 2 und 7 identifizieren Franz Neumann als Verfasser dieses Führers. Vgl. außerdem NA, RG 59, R\&A 1323.9, den "Labor"-Teil des „Civil Affairs Handbook Germany", Army Service Forces Manual M 356-9, 3.6. 1944, von Franz Neumann und Oscar Weigert; dazu auch Wiesner, Die organisierte Arbeiterbewegung, in: Erd (Hrsg.), Reform und Resignation, S.172-182, sowie Fichter, Besatzungsmacht und Gewerkschaften, S. $59 \mathrm{ff}$.

${ }^{45}$ NA, RG 226, E 44, b 7, f: VII.E. Miscellaneous 1655.28, Schreiben vom 22.4. 1944; wie obiges Zitat zeigt, ist diese Kritik offenbar berücksichtigt worden.

46 Wiesner, Die organisierte Arbeiterbewegung, in: Erd (Hrsg.), Reform und Resignation, S.182.

${ }^{47}$ In diesem Zusammenhang wie Söllner, Archäologie der Demokratie, Bd. 1, S.256f., von einem "strategischen Traditionalismus“ im Sinne einer "vorweggenommene[n] Reaktion auf den erwartbaren Konservatismus der Militärregierung in Sachen Arbeiterbewegung“ zu sprechen, scheint überzogen; vgl. dazu z. B. den Vorschlag der Tarnow-Gruppe in Schweden, die für die unmittelbare Nachkriegszeit sogar die Übernahme des Verwaltungsapparates der DAF erwog, um eine möglichst schnelle Organisation der Arbeiter zu gewährleisten, in: NA, RG 226, E 115, b 32, f 37: Germany - Post War Reconstruction (Bericht aus Stockholm vom 19.10. 1943). 
Davon abgesehen scheint man sich in R\&A allerdings auch nicht so sicher gewesen zu sein, inwieweit sich die organisierte deutsche Arbeiterschaft tatsächlich für fortschrittliche Veränderungen stark machen würde. So rechnete man in R\&A beispielsweise damit, daß eine wiederbegründete SPD in traditionellen Bahnen bleiben würde und die Mehrheit ihrer Mitglieder wieder aus den Reihen der Arbeiter im Alter von 30 bis 60 Jahren rekrutieren würde, denen, wie R\&A meinte, vor allem an Frieden und möglichst großer gesellschaftlicher Stabilität gelegen sein würde. Zudem erwartete man, daß sich eine weitverbreitete Furcht vor dem Bolschewismus im Nachkriegsdeutschland zuungunsten der KPD, nicht aber notwendigerweise zugunsten der SPD auswirken würde. Statt dessen war nach Ansicht von R\&A eher damit zu rechnen, daß die Nachkriegssituation den bürgerlichen Parteien und insbesondere der Zentrumspartei eine Schlüsselposition verschaffen würde: „The Party may become the rallying ground for all forces that try to stabilize Central European society by preventing a social revolution as well as a new form of German imperialism. "48

Doch obwohl diese - wie sich herausstellen sollte - durchaus realitätsnahen Visionen wenig Hoffnung darauf ließen, daß die politischen Ideale der in der Central Europe Section beschäftigten deutschen Emigranten im Nachkriegsdeutschland verwirklicht werden würden, verlor man in dieser R\&A-Abteilung nur selten aus den Augen, daß diese Ideale eben auch nicht von einer Militärregierung umgesetzt werden konnten. Die meisten der von R\&A ausgearbeiteten Civil Affairs Guides bezeugen vielmehr einen derartig nüchternen Pragmatismus, daß der von der R\&A-History erhobene Anspruch, die Abteilung sei beständig bestrebt gewesen, der Militärregierung keinerlei "messianische“ Rolle zuzuweisen, schon fast als Understatement erscheint. Immer wieder wird in diesen Führern davon ausgegangen, daß die Militärregierung aus pragmatischen Gründen bestehende Verwaltungs- und Organisationsformen übernehmen müsse und daß deutsches Personal - aus pragmatischen wie politischen Gründen - unter Kontrolle der Militärregierung weitreichende und durchaus auch politisch sensitive Verantwortungen zu übernehmen haben würde.

Die Ausnahmen, die dabei zuweilen doch gemacht wurden, reflektierten dann wieder Elemente aus den von Neumanns Behemoth beeinflußten R\&A-Studien zu Grundlagen und Herrschaftsmechanismen des NS-Regimes. Sobald es etwa um das deutsche Beamtentum ging, unterschieden die von R\&A ausgearbeiteten Richtlinien in einer Weise zwischen einzelnen Gruppen, die an die von Neumann in Behemoth getroffene Unterscheidung zwischen ,jenen mit politischer Entscheidungsmacht und denen, die lediglich ausführende Organe sind ${ }^{\alpha}$, erinnert. Als Beispiel für die ersteren hatte Neumann die „Ministerialbürokratie“ genannt, für die letzteren nannte er „die Polizei und unteren Verwaltungsbehörden “49. Der R\&A-Entwurf zu „Principles of Administration and Civil Service in Germany " ${ }^{50}$ sah denn auch prompt die Entlassung aller hochgestellten Staatsbeamten vor - nach R\&A-Schätzungen ungefähr 7760 Personen.

48 NA, RG 59, R\&A 1655.1, War Department Pamphlet No. 31-166, Civil Affairs Guide, „Policy Toward Revival of Old Parties and Establishment of New Parties in Germany“, 22.7. 1944.

${ }^{49}$ Neumann, Behemoth, S. 430.

50 NA, RG 59, R\&A 1655.12, War Department Pamphlet No. 31-113, Civil Affairs Guide, „General Principles of Administration and Civil Service in Germany ${ }^{a}, 22.7$. 1944; der Titel dieses Führers wurde mehrfach geändert; Verfasser war nach NA, RG 226, E 44, b 1 und 2 Otto Kirchheimer; zur Diskussion um diesen Führer siehe ebenda, b 3. 
In der Diskussion um diesen Entwurf kehrte sich die zwischen R\&A und FEA übliche Frontstellung um, denn die FEA ließ es sich nicht entgehen, ihrerseits nun endlich einmal R\&A wegen der zu erwartenden Überlastung der Militärregierung kritisieren zu können. In R\&A gestand man daraufhin zwar zu, daß sich die aus diesen Maßnahmen erwachsende Arbeitsbelastung für die Militärregierung in der Tat als beträchtlich erweisen könnte, hielt dies jedoch für eine Übergangsperiode für unvermeidlich, da die Beibehaltung von NS-Personal schließlich nicht vertretbar sei. Andererseits hielt man in R\&A aber eine Übernahme weiter Teile der Kriminalpolizei - nach einer gründlichen Entnazifizierung und unter strikter Überwachung der Militärregierung - für durchaus vertretbar und argumentierte, daß der Militärregierung nicht zuletzt wegen des befürchteten nationalsozialistischen „Untergrunds" eine schlagkräftige Polizei zur Verfügung stehen müsse ${ }^{51}$.

Während der Umfang der von R\&A für das War Department geleisteten Arbeit mit den hier aufgeführten Beispielen lediglich angedeutet werden kann ${ }^{52}$, kommt die Eigenart dieser Arbeiten - insbesondere die in ihnen vertretene politische Linie - deutlich zum Ausdruck. Es ist nicht zuletzt die Gebrochenheit dieser politischen Linie, die diese Arbeiten charakterisiert. Zu einem Teil ist diese Gebrochenheit wohl tatsächlich, wie Söllner vermutet hat, durch „das politische Realitätsprinzip, das dem utopischen Entwurf eines sozialistischen Nachkriegsdeutschlands mit der ,law and order'Herrschaft der Militärregierung in den Weg treten mußte ${ }^{\alpha 53}$, zu erklären. Die Civil Affairs Guides waren Auftragswerke des War Department, und in R\&A bewies man zumindest vordergründig - beträchtliches Einfühlungsvermögen in die Interessen dieses Auftraggebers. Dabei versuchte R\&A jedoch, die im Interesse des War Department liegende Beschränkung der Aufgaben und Kompetenzen einer Militärregierung dahingehend zu interpretieren, daß eine wirkliche Demokratisierung der deutschen Gesellschaft nicht von einer Militärregierung dekretiert und autoritär durchgesetzt werden könne, sondern nur von den Deutschen selbst geleistet werden konnte. Die mit den Anfängen eines solchen Demokratisierungsprozesses unweigerlich verbundenen Unruhen und Unwägbarkeiten ließen sich - trotz gegenteiliger Versicherung von R\&A - freilich kaum mit der als Priorität der Militärregierung vorgegebenen Wiederherstellung von "law and order" und der unter dem Gesichtspunkt von "military necessity" ebenso wichtigen Wiederaufnahme grundlegender öffentlicher Dienstleistun-

51 NA, RG 59, R\&A 1655.2, War Department Pamphlet No. 31-107, Civil Affairs Guide, „Police and Public Safety in Germany“, 22.7. 1944; nach NA, RG 226, E 44, b 2 von John Herz ausgearbeitet. Katz, Foreign Intelligence, S.47 und Anmerkung 52, nennt Franz Neumann als Verfasser dieses Führers. Höchstwahrscheinlich handelt es sich dabei um ein Mißverständnis. Neumann mag zwar am "clearance“-Prozeß dieses Guides beteiligt gewesen sein, doch waren die Arbeiten für die Civil Affairs Guides insgesamt nach thematischen Schwerpunkten aufgeteilt also z.B. "economic guides", "labor guides", "adjustment of the administrative system", etc. Für den letztgenannten Bereich, zu dem auch der hier diskutierte Führer gehörte, waren in erster Linie John Herz und Otto Kirchheimer zuständig, während Franz Neumann als R\&A"labor"-Spezialist eingeteilt war.

52 Für eine Auflistung aller von R\&A ausgearbeiteten Civil Affairs Guides siehe Anhang; vgl. auch NA, RG 59, R\&A 1458, „Research in Preparation of AMG in Germany“, [o.D.]; eine Auflistung aller Civil Affairs Guides findet sich in NA, RG 59, R\&A 2438, "The Civil Affairs Guide Program for Germany: An Analysis of its Principles and Aims", 23.10. 1944.

53 Söllner (Hrsg.), Archäologie der Demokratie, Bd.1, S. 203. 
gen vereinbaren. R\&A versuchte, diesem Dilemma durch weitgehende Kompromißbereitschaft in bezug auf die Wiederherstellung technischer und administrativer Dienstleistungen zu begegnen, und hatte insofern kaum Skrupel, in diesen Bereichen immer wieder die vorläufige Beibehaltung bestehender Institutionen und Organisationformen zu empfehlen ${ }^{54}$. Während R\&A dabei in einigen Fällen - wie beispielsweise den Kartellen - extrem weit gehen wollte, um die Militärregierung vor „politischen“ Aufgaben zu bewahren, hielt man andererseits aber auch hartnäckig an dem von der Abteilung als so wichtig erachteten Grundsatz fest, daß linke Gruppen durch die Militärregierung bevorzugt werden sollten, und konnte, was bemerkenswert erscheint, entsprechende Empfehlungen auch trotz expliziter Kritik des War Department in die Richtlinien einbringen ${ }^{55}$.

Die hier diskutierte Problematik wird in einem nach Abschluß der Arbeiten an den Civil Affairs Guides von R\&A verfaßten Bericht zum „Civil Affairs Guide Program for Germany" in bezeichnender Weise angesprochen. Offenbar fühlte man in R\&A nämlich die Notwendigkeit, sich gleichzeitig gegen den Vorwurf, daß die Civil Affairs Guides den traditionellen MG-Grundsatz größtmöglicher Nichteinmischung mißachteten, und gegen die entgegengesetzte Kritik verwahren zu müssen, daß die in den Führern gegebenen Richtlinien den in Deutschland notwendigen Veränderungen nicht ausreichend Rechnung trügen: „While the Guides are never interventionist to an unnecessary degree, and while they utilize the existent framework whenever possible, they definitely represent a positive program of action; i.e., they advocate extensive participation by Military Government, in both the planning and execution of measures changing radically the pattern of German life."

Das eigentliche Dilemma war damit aber bestenfalls angedeutet, keinesfalls gelöst. Denn letztlich gründete es in der Frage, wie radikal die angestrebte Veränderung der Strukturen deutschen Lebens sein sollte - radikal im demokratisch-liberalen Verständnis amerikanischer Prägung mit dem Ziel, das nationalsozialistische Deutschland zu einer "fair replica of the New Deal“ umzuformen ${ }^{56}$, oder radikal im Sinne der in der Tradition der europäischen Arbeiterbewegung stehenden R\&A-Emigranten, die auf "profound socio-economic changes [...] through the efforts of those German groups who are opposed to the policies of imperial aggrandizement" hofften ${ }^{57}$.

${ }^{54}$ Am krassesten vielleicht in NA, RG 59, R\&A 1759.1, War Department Pamphlet No. 31-145, Civil Affairs Guide, „Administration of German Roads and Motor Transport", 22.7. 1944: "The Nazi German road administration is an efficient centralized organization [...] headed by men who know and have worked with the problems of the country as a whole, and it is served by specialized research organizations and technical staffs [...] The Allies would be unwise to reorganize, decentralize, or ignore it at a time when they will have to cope with tremendous national and international problems connected with the distribution of supplies and the repatriation of peoples."

55 Vgl. dazu auch die im folgenden ebenfalls angesprochene Studie NA, RG 59, R\&A 2438, ,The Civil Affairs Guide Program for Germany: An Analysis of its Principles and Aims“, 23.10. 1944: „The principle of equal treatment of all political parties [...] will not be immediately applicable in post-war Germany"; in dem Abschnitt über die von der Militärregierung anzustrebende "Promotion of Liberal and Democratic Institutions" wird wiederum „Protection of the Rights of Labor" an erster Stelle angeführt.

${ }^{56}$ Dies hatte R\&A im Hinblick auf die Absichten der FEA geargwöhnt, siehe oben S.126.

${ }^{57}$ NA, RG 226, E 1, b 1, f 8, "What is the Purpose of Military Government?" 
Gerade an dieser Frage scheint die von R\&A vertretene politische Linie aber zweifach gebrochen. Denn daß die Civil Affairs Guides einerseits die Hoffnungen der linken Emigration auf ein Wiederaufleben der Linken und eine von ihr ausgehende entscheidende Gestaltungskraft in der Nachkriegszeit widerspiegeln, dann aber auch relativ unvermittelt die Vision danebenstellen, daß sich eine bürgerliche Mitte mit ihrer scheinbaren politischen Neutralität in einem politikmüden, vorrangig an materieller und sozialer Sicherheit interessierten Nachkriegsdeutschland als stärkste Kraft erweisen könnte, entsprang offenbar nicht nur der Befürchtung, daß die Militärregierung der Versuchung erliegen könnte, ihre legitimen Kompetenzen zu überschreiten und ihre tatsächlichen Wirkungsmöglichkeiten zu überschätzen, oder daß sie - „by a misguided emphasis on achieving ends that can be attained only by strengthening the power of the traditional ruling groups - einer Restauration der "herrschenden Klassen“ den Weg bereiten würde. Die Eindringlichkeit, mit der R\&A diese Gefahren immer wieder beschwor, illustriert zwar, daß man allen Grund zu haben glaubte, vor solchen Entwicklungen warnen zu müssen. Doch darüber hinaus hegte man in R\&A durchaus auch Zweifel an der politischen oder gar revolutionären Energie einer Linken, deren einstmals stärkste Kraft, die SPD, man als „greatly compromised by its failure to resist effectively the rise of the Nazi movement" betrachtete $^{58}$. Gleichzeitig glaubte man in R\&A in Rechnung stellen zu müssen, daß gerade die politische Linke unter der nationalsozialistischen Herrschaft viele ihrer führenden Persönlichkeiten verloren hatte und letztlich vollkommen atomisiert auf den Kampf ums nackte Überleben reduziert worden war. Zudem sah man früh die Möglichkeit eines unversöhnlichen Ost-West-Antagonismus, der nach Ansicht der Abteilung politisch fortschrittlichen Entwicklungen in Deutschland nur abträglich sein konnte. Vor dem Hintergrund all dieser Überlegungen schien es wohl naheliegend, daran zu denken, daß hochfliegende Hoffnungen auf eine vitale Linke und deren energisches Streiten für die Verwirklichung sozialistischer Ideale sich in der relativen Bequemlichkeit des Exils ganz anders ausnehmen mochten als unter den desolaten Bedingungen der unmittelbaren Nachkriegszeit.

Wie bereits angedeutet, erschöpfte sich jedoch der Beitrag der R\&A-Branch zur Planung und Vorbereitung der amerikanischen Besatzungspolitik nicht in der Ausarbeitung dieser Civil Affairs Guides. Neben diesen politisch „brisanten “ Arbeiten steuerte R\&A auch das voluminöse, als rein informatives Nachschlagewerk gedachte Civil Affairs Handbook Germany bei ${ }^{59}$. Dieses Handbuch war vom War Department ebenfalls im Frühjahr 1943 in Auftrag gegeben worden ${ }^{60}$; es umfaßte nach seiner Fertigstellung im Sommer 1944 siebzehn einzelne Bücher - einige davon über 200 Seiten stark -, die den Offizieren der US-Militärregierung in Deutschland als "ready reference source

${ }^{58}$ Hier zit. aus NA, RG 59, R\&A 1549, „The Social Democratic Party of Germany“, 1.9. 1945; ähnliche Beurteilungen finden sich in einer Reihe anderer R\&A-Arbeiten, vgl. z. B. NA, RG 59, R\&A 992, "The Underground Movement in Germany“, 27.9. 1943; NA, RG 59, R\&A 1655.1, War Department Pamphlet No. 31-116, Civil Affairs Guide, „Policies toward Revival of Old Parties and Establishment of New Parties in Germany“, 22.7. 1944; diese Arbeiten auch zum Folgenden.

59 NA, RG 59, R\&A 1323.1-17, Army Service Forces Manual M356-1, Civil Affairs; siehe auch NA, RG 59, R\&A 1458, „Research in Preparation of AMG in Germany“, [o.D.].

60 NA, RG 226, E 59, II, Minutes of Meetings: 31.3. 1943. 
books containing the basic factual information needed for planning and policy making " dienen sollten ${ }^{61}$. Diese Bücher behandelten Themen wie den sozialen Hintergrund des nationalsozialistischen Deutschlands, den NS-Regierungsapparat sowie die in den besetzten Staaten Europas errichteten deutschen Besatzungsregime, Geographie, Industrie und Wirtschaft sowie das öffentliche Dienstleistungswesen. In die Ausarbeitung dieser Handbücher scheinen immer wieder auch relevante Abschnitte der R\&A-Studien zum nationalsozialistischen Deutschland eingeflossen zu sein, wobei freilich der als neutral und informativ postulierte Charakter dieser Handbücher die Übernahme deutlich interpretierender oder gar wertender Passagen im allgemeinen ausschloß ${ }^{62}$. Dennoch setzt sich in manchen dieser Handbücher das für R\&A-Arbeiten so charakteristische Bestreben fort, gesellschaftliche und politische Verhältnisse in ihren historischen Kontext zu stellen und sie aus ihrer historischen Entwicklung heraus zu erklären, womit sich nicht selten - wenn auch nur verdeckt - doch wieder politische Implikationen verbanden ${ }^{63}$.

Die von R\&A/Washington im Auftrag des War Department geleisteten Arbeiten bildeten schließlich auch die Grundlage für den Beitrag, den die R\&A-Außenstelle in London für die in Großbritannien stationierten Planungsstäbe des Militärs sowie für das in Shrivenham eingerichtete Ausbildungslager für Offiziere der künftigen Militärregierung leistete ${ }^{64}$. Freilich litt auch die Arbeit von R\&A/London spürbar unter dem Fehlen grundlegender politischer Richtlinien; zudem wurde die Arbeit des Londoner R\&A-Büros aber auch noch erheblich durch die ungeklärte Verteilung von Kompetenzen zwischen den verschiedenen militärischen Stellen in Großbritannien behindert. Letzteres ließ R\&A/London im unklaren darüber, mit welchen Abteilungen man in erster Linie zusammenarbeiten sollte, und so schwankten die Mitarbeiter von R\&A/London immer wieder zwischen hochgespannten Erwartungen an die politische Bedeutung und Reichweite der von ihnen geleisteten Arbeit und dem Gefühl, daß ihre Bemühungen letztlich doch im Sande verlaufen würden. So herrschte nach anfänglichem Enthusiasmus gegen Ende 1943 in der Abteilung ein Gefühl der Frustration vor, doch die ersten Monate des Jahres 1944 brachten dann einen raschen und zunächst vielversprechend erscheinenden Auf- und Ausbau der Beziehungen zwischen R\&A/London und

${ }^{61}$ NA, RG 59, R\&A 1323.1, Introduction.

62 Söllner, Archäologie der Demokratie, Bd.1, S. 91 ff., knüpft an den von ihm in deutscher Übertragung auszugsweise abgedruckten Teil 1323.2T des Handbuchs zu "Government and Administration: Economic Controls in Nazi Germany“, 1.2. 1944, weitreichende Hypothesen.

63 Politische Implikationen in dem Sinne, den etwa Dorn, Debate over American Occupation Policy“, in: PSQ 72/4, besonders S. $483 \mathrm{ff}$, mit dem Zusammenhang zwischen „wartime, images' of National Socialism" und den davon beeinflußten Vorstellungen zur Nachkriegspolitik gegenüber Deutschland angedeutet hat. Vgl. in diesem Zusammenhang auch Katz, Foreign Intelligence, S. 73 ff., zu dem laut Katz u. a. von Felix Gilbert verfaßten Abschnitt 1323.1A des Handbuches zum "Background of the Nazi Regime“, 18.10. 1944.

${ }^{64}$ Dazu und zum Folgenden NA, RG 226, E 91, b 9: War Diary, R\&A-Branch, OSS London, Vol. 8: Civil Affairs. Zu den anfänglich in Großbritannien, später auch in Frankreich stationierten und schließlich nach Deutschland vorrückenden militärischen Stellen, die mit der Planung und Vorbereitung der amerikanischen Besatzungspolitik befaßt waren, vgl. Ziemke, The U.S. Army in the Occupation of Germany, S.23ff., Zink, Military Government in Germany, S.12ff., bei beiden Autoren auch eine kritische Darstellung der Verhältnisse - insbesondere des Ausbildungsprogramms - in Shrivenham. Außerdem: Clark, Conflict over Planning, in: Friedrich (u. a.), American Experiences in Military Government, S. $211 \mathrm{ff}$. 
G-5/SHAEF, der mit Civil Affairs befaßten Abteilung des Supreme Headquarter Allied Expeditionary Forces (SHAEF). In R\&A gewann man zunehmend den Eindruck, daß man entscheidend zu der von G-5 geleisteten Arbeit beitragen konnte, und in Shrivenham wurde die Unterstützung von $R \& A$ offenbar tatsächlich bald als nas welcome as the flowers in spring" bezeichnet. Harold Deutsch, der inzwischen in London stationiert war, drängte R\&A/Washington im März 1944, „[to] work literally day and night", um das Büro in London mit dringend benötigten Studien zu versorgen, denn, wie er hinzufügte: ,We are all convinced that there is virtually no limit to the ways in which we can be of service to Shrivenham. "Für den von R\&A/London geleisteten Beitrag zum Ausbildungsprogramm in Shrivenham war Walter Dorn zuständig ${ }^{65}$. Er arbeitete in dieser Funktion beispielsweise an einer in Shrivenham organisierten Manöverübung mit, in der fiktiv die Übernahme Hessens durch die Militärregierung durchgespielt wurde ${ }^{66}$. Die verfügbaren Informationen und Unterlagen erwiesen sich dabei allerdings als unzureichend und wurden daraufhin von Dorn mit enormem Einsatz überarbeitet ${ }^{67}$.

Die Deutschlandexperten von R\&A/London arbeiteten im März 1944 schließlich auch ein Papier zu den "Civil Affairs Problems in Germany" aus, das nach Bekunden des R\&A War Diary die Planer in G-5 so beeindruckte, "that Dr. Armstrong [R\&A/ London] was associated with the German Country Unit in the virtual position of assistant planner “" . Dies verschaffte R\&A/London die Möglichkeit, kontinuierlich zur Arbeit der German Country Unit beizutragen. Diese Einheit war im Februar 1944 eingerichtet worden ${ }^{68}$; ihr Personalstab setzte sich aus britischen und amerikanischen Offizieren zusammen, die - freilich auch ohne klare politische Richtlinien - die alliierte Militärverwaltung vorbereiten sollten und dabei anfänglich noch von einer gemeinsamen anglo-amerikanischen Besatzungspolitik ausgingen. Arbeitsschwerpunkt dieser Einheit wurde die Ausarbeitung von Handbüchern für die Militärregierung, wobei sich die Unterstützung von R\&A offenbar bald als so wertvoll erwies, ,[that] G-5 officials $[\ldots]$ repeatedly expressed extreme eagerness to have OSS personnel available for consultation throughout the occupation period ${ }^{469}$.

Der sich aus den Kontakten mit diesen militärischen Stellen nährende Enthusiasmus des R\&A-Büros in London wurde jedoch bald wieder gedämpft, als die Abteilung

${ }^{65} \mathrm{Vgl}$. dazu Dorns Erinnerungen in Dorn, Inspektionsreisen in der US-Zone, S. $24 \mathrm{ff}$.

${ }^{66}$ Diese Übung ist auch erwähnt bei Ziemke, The U.S.Army in the Occupation of Germany, S. 65.

${ }^{67}$ Der praktische Wert der von R\&A beigesteuerten Arbeiten ist unterschiedlich bewertet worden; überaus kritisch Zink, American Military Government in Germany, S.18; vgl. dagegen Noblemans Diskussionsbeitrag zum Vortrag von Ziemke in Wolfe (Hrsg.), Proconsuls, S.72f., sowie Wiesner, Die organisierte Arbeiterbewegung, in: Erd (Hrsg.), Reform und Resignation, S. $175 \mathrm{f}$.

${ }^{68}$ Vgl. dazu Ziemke, The U.S.Army in the Occupation of Germany, S.80ff., sowie Zink, The United States in Germany, S. $18 \mathrm{ff}$.

${ }^{69}$ NA, RG 226, E 1, b 1, f 3 (Rechenschaftsbericht der Europe-Africa Division); vgl. auch NA, RG 226, E 99, b 104, "Achievements of the Research and Analysis Branch During the Past Year", 23.4. 1945: „Brigadier General Holmes, who was in charge of Civil Affairs in ETOUSA, has stated that R\&A , had provided G-5 [...] with better studies on Germany than the combined contribution of all other agencies [...] Our planning for Germany would have been impossible without the contribution of R\&A research'." 
nach ihrem anfänglichen Wissensvorsprung vor allem wegen Personalmangels hinter die bald mehr als 100 Mitarbeiter umfassende German Country Unit zurückfiel. Zunehmend fraglich erschien überdies, ob der Arbeit der in Großbritannien stationierten Planungsstäbe angesichts der ungeklärten Kompetenzen innerhalb des Militärs sowie der noch immer ausstehenden politischen Richtlinien für die Militärregierung letztlich überhaupt politische Relevanz zukommen würde. In der Tat wurde die German Country Unit im Spätsommer 1944 aufgelöst. Zwar übernahm die danach eingerichtete USKontrollratsgruppe einen Großteil des Personals der German Country Unit und baute auf die von ihr geleistete Arbeit auf0; doch sah man sich in R\&A/London durch diese Entwicklung in der Hoffnung getäuscht, politisch relevante Arbeit auf der Ebene von SHAEF leisten zu können.

Der Spätsommer 1944 brachte jedoch noch andere Entwicklungen, die die Bedeutung des von R\&A geleisteten Beitrags zur Planung der amerikanischen Militärregierung in Frage zu stellen schienen. Die umfangreichen Arbeiten für die Civil Affairs Guides waren gerade abgeschlossen, und man glaubte in R\&A, mit einiger Befriedigung feststellen zu können, daß das von den in Großbritannien stationierten Planungsstäben ausgearbeitete „Handbook for Military Government in Germany“, die sogenannte "SHAEF Bible“, viele der in den R\&A-Guides entwickelten Überlegungen widerspiegelte, als dieses Handbuch dem amerikanischen Finanzminister Henry Morgenthau zu Augen kam ${ }^{71}$. Ebenso wie sein einflußreicher Assistent Harry Dexter White war Morgenthau der Ansicht, daß die in dem Handbuch formulierten Richtlinien völlig unzureichend seien, um eine Bedrohung des Friedens durch Deutschland künftig auszuschließen. Im Treasury Department entwarf man daraufhin alternative Grundsätze zur Behandlung Deutschlands, die unter der Bezeichnung "Morgenthau-Plan“ in die Geschichte eingegangen sind ${ }^{72}$. Der sogenannte „Morgenthau-Plan" empfahl als Sicherheitsmaßnahme gegen künftige deutsche Aggressionen einen weitgehenden Abbau der deutschen Industrie und die unter dem Schlagwort „Pastoralisierung“ bekanntgewordene Reduktion der deutschen Wirtschaft auf den landwirtschaftlichen Bereich. Es gelang Morgenthau zunächst, den Präsidenten zur Billigung dieser Grundsätze zu

70 Vgl. dazu Zink, The United States in Germany, S.24ff.

${ }^{71}$ NA, RG 226, R\&A-History, Civil Affairs Guides, S. 102. Holborn hat später gemeint: „It is probably correct to say that much of the thinking that Secretary Morgenthau objected to originated with the OSS." Holborn, American Planning of Military Government, in: ders., Germany and Europe, S.253. Vgl. auch Clark, Conflicts over Planning, in: Friedrich (u. a.), American Experiences in Military Government, S.211 ff. Zu der sich an diesem Handbuch entzündenden Kontroverse Ziemke, The U.S. Army in the Occupation of Germany, S.83ff. In der Literatur ist gelegentlich festgestellt worden, daß sich dieses Handbuch „auf der ausgewogenen Linie der Auffassungen des State Departments [hielt]", hier nach Deuerlein, Die Einheit Deutschlands, Bd. I, S.47; ähnlich z.B. Benz, Von der Besatzungsherrschaft zur Bundesrepublik, S. 22.

72 Siehe dazu Morgenthau, Germany is Our Problem; Blum, Morgenthau Diaries, 1941-1945, S. 327 ff., sowie Kimball, Swords or Ploughshares, und Backer, From Morgenthau Plan to Marshall Plan, in: Wolfe (Hrsg.), Proconsuls, S. 155-165. Es ist verschiedentlich vermutet worden, daß in Wirklichkeit Morgenthaus Assistent White der Spiritus rector des sog. "MorgenthauPlans“ war (so z. B. Balabkins, Germany Under Direct Controls; vgl. auch den unten, Anmerkung 75, erwähnten Tagebucheintrag Sherman Kents), doch ist dies auch immer wieder entschieden zurückgewiesen worden, so z.B. Dorn, American Occupation Policy, PSQ 72/4, S.494; ganz ähnlich Holborn, American Planning, in: ders., Germany and Europe, S. 259. 
bewegen, und auch bei der im September 1944 in Quebec stattfindenden Konferenz zwischen Roosevelt und Churchill wurden die vom Treasury Department ausgearbeiteten Grundsätze zunächst angenommen. Sowohl Roosevelt als auch Churchill sahen sich allerdings bald veranlaßt, ihre in Quebec erklärte Zustimmung zum „Morgenthau-Plan" unter dem Druck ihrer Berater und der öffentlichen Meinung zu widerrufen. Dennoch gelang es Morgenthau letztlich, nicht nur die Ausgabe des „Handbook for Military Government in Germany" erheblich zu verzögern, sondern auch die Planungen für die amerikanische Besatzungspolitik in seinem Sinne zu beeinflussen. Der "Strafcharakter" der für die amerikanischen Besatzungstruppen in Deutschland zunächst grundlegenden Direktive JCS 1067 ist dann auch allgemein auf Morgenthaus Einfluß zurückgeführt worden.

Diese sich im Spätsommer 1944 abzeichnenden Entwicklungen schienen darauf hinzudeuten, daß die von R\&A bei der Planung und Vorbereitung der amerikanischen Besatzungspolitik geleistete Arbeit letztlich bestenfalls als allen politischen Überlegungen entkleidete, auf bloße Material- oder Datensammlungen reduzierte Hintergrundinformation zum Tragen kommen mochte. Hajo Holborn hatte schon Mitte August die Befürchtung geäußert, daß R\&A angesichts der noch immer ausstehenden Regelung zentraler politischer Probleme kaum hoffen konnte, "to produce anything of value ${ }^{\text {“73. }}$ Auch die Bilanz, die in der R\&A-History zur Arbeit an den Civil Affairs Guides gezogen wird, ist eher ambivalent. So wird einleitend darauf hingewiesen, daß der Rückblick auf die schwierige, ja geradezu verzweifelte Zeit, in der die Civil Affairs Guides entstanden, eher schlechte denn gute Erinnerungen wachrufe ${ }^{74}$. Andererseits habe R\&A selbst aber von dieser Arbeit profitiert, denn durch die anstrengenden, zahlund endlosen Besprechungen zwischen den beteiligten Abteilungen der Europe-Africa Division sei die Atmosphäre innerhalb der Division verbessert worden. Zudem hätte sich R\&A in den zahlreichen Besprechungen der im Zusammenhang mit dem Projekt gebildeten Ausschüsse und Unterausschüsse den Ruf einer Organisation erworben, "which had wrestled with practically every phase of military government in Germany, which had thought deeply and systematically of underlying problems, and which had come out of the turmoil with an enlightened basic position and some sound notions as to how it should be implemented". Darüber hinaus hatte man in R\&A schließlich trotz allem das Gefühl, mit der Ausarbeitung der Guides dem "national interest [... if not perfectly, at least well " gedient zu haben, denn, so wird argumentiert, "the guides had a fairly wide circulation in Washington at a time when everyone was groping for basic policy; a good many of them reached the planners in G-5/SHAEF [...] The content of nearly all of them became known to the officers of G-5 well in advance of the drafting of any final plans." Zudem beansprucht die R\&A-History, daß die Führer "an important place in the directives of EAC" gehabt hätten.

Auch die Intervention Morgenthaus machte den von R\&A geleisteten Beitrag nach Darstellung der R\&A-History keineswegs zunichte: „When the SHAEF Bible was recalled through action of the President and the Secretary of War the guides constituted the main corpus of thought on the problems of military government in Germany, and when the SHAEF Bible in revised form was issued, it incorporated practically all the

${ }^{73}$ Zit. nach Katz, Foreign Intelligence, S.79.

${ }^{74}$ Dazu und zum Folgenden NA, RG 226, R\&A-History, Civil Affairs Guides, S. $102 \mathrm{ff}$. 
content of the Guides. ${ }^{\alpha 75}$ Im übrigen glaubte man in R\&A, daß die Guides, die gedruckt und als säuberlich gebundene Broschüren verteilt wurden ${ }^{76}$, schließlich nicht ohne Einfluß auf die alltägliche Arbeit der Militärregierung bleiben würden. Auch wenn kaum anzunehmen sei, daß sich MG-Offiziere in allen Einzelheiten an die in diesen Guides gegebenen Empfehlungen halten würden, so war man in R\&A doch der Überzeugung, daß ihre Maßnahmen von "philosophy and content of the guides" geprägt sein würden.

Hajo Holborn hat später eine ähnliche Sicht vertreten, als er über die Civil Affairs Guides schrieb: „[They] incorporated some policies that had never been officially adopted, or in any event did not conform in important respects to the thinking of the highest American policy-makers [...] The influence of the whole undertaking should perhaps not be overrated, but it was of some consequence that the future MG officers were presented for the first time with a systematic analysis of the future military-government programs in Germany. "77 Tatsächlich hätte Holborn die Bedeutung der Civil Affairs Guides guten Gewissens noch etwas höher veranschlagen können, denn General Hilldring, der Leiter der CAD im War Department, hatte sich ihm gegenüber in einem Anfang Februar 1945 stattfindenden Gespräch nicht nur sehr positiv über dieses Projekt geäußert, sondern den Führern auch einen gewissen Einfluß bei der Revision der Direktive JCS 1067 zugeschrieben ${ }^{78}$.

Letztlich ist die politische Relevanz der von R\&A im Rahmen des Civil Affairs-Programms ausgearbeiteten Materialien jedoch wohl nur schwer zu bestimmen - die Frage danach erübrigt sich aber keineswegs mit dem Verweis auf JCS 1067 und die durch diese Direktive bestimmten Maßnahmen der amerikanischen Militärregierung. Zwar mögen die hier vorgestellten R\&A-Arbeiten nach Kriterien einer rigide verstandenen Diplomatiegeschichte kaum eindeutig identifizierbare Spuren in den Dokumenten hinterlassen haben, die die offizielle amerikanische Besatzungspolitik definierten ${ }^{79}$, doch waren schließlich weder die Civil Affairs-Handbücher noch die Verwaltungsführer auf dieser Ebene angesiedelt. Sie waren vielmehr als praktische Hilfen für eine Militärregierung konzipiert, deren Funktionen und Aufgaben sowohl zeitlich wie inhaltlich eng begrenzt sein sollten, wobei die Handbücher in erster Linie als informative Nachschlagewerke gedacht waren, während die Civil Affairs Guides letztlich unverbindliche Empfehlungen zur Handhabung und Lösung administrativer und politischer Problem gaben ${ }^{80}$. Nur des-

75 Vgl. dazu auch den bei Winks, Cloak \& Gown, S. 94 zitierten Tagebucheintrag Sherman Kents, der feststellte, daß Kriegsminister Stimson der von R\&A vertretenen Linie letztlich doch step by step" wieder Geltung verschaffte, „making the Harry White policy shrink into the background“. Zur Revision des Handbuchs vgl. Ziemke, The U.S. Army in the Occupation of Germany, S. $87 \mathrm{ff}$.

${ }_{76}$ Dazu auch NA, RG 226, E 37, b 2, f: Civil Affairs-Miscellaneous Correspondence: Check List of Civil Affairs Guides and Information Guides on Europe (Stand vom 1.2. 1945).

77 Holborn, American Planning of the Military Government, in: ders., Germany and Europe, S. 253.

78 Bericht Holborns an William Langer, 10.2. 1945, in NA, RG 226, E 37, b 2, f: Civil AffairsMiscellaneous Correspondence.

79 Vgl. zu dieser Problematik Zink, The United States in Germany, iv: „One of the strong impressions which the author carried with him out of both military and High Commission service in Germany was that, essential as official documents may be, they do not tell the whole story."

${ }^{80} \mathrm{Vgl}$. dazu den in jedem Civil Affairs Guide als Vorbemerkung enthaltenen Hinweis (siehe Anhang). 
halb war es überhaupt möglich, daß die in den Civil Affairs Guides gegebenen Empfehlungen zum Teil kaum mit der schließlich zur offiziellen Besatzungspolitik erklärten politischen Linie vereinbar waren ${ }^{81}$. In diesem Zusammenhang muß auch in Rechnung gestellt werden, daß die Arbeit am Civil Affairs-Programm noch vor der Intervention Morgenthaus im Sommer 1944 abgeschlossen wurde und daß es auf der relativ untergeordneten Ebene dieser Führer offensichtlich möglich war, die von Morgenthau beeinflußten Revisionen weitgehend zu ignorieren. Freilich tritt man an dieser Stelle in die Kontroverse darüber ein, wie weit der Einfluß Morgenthaus sich überhaupt auswirkte. Wie bereits angesprochen, ist der "Strafcharakter" der offiziell bis Mitte 1947 geltenden Direktive JCS 1067 im allgemeinen auf Morgenthaus Einfluß zurückgeführt worden. Morgenthau selbst hat die Ansicht vertreten, daß die von ihm entwickelten Grundsätze zur Behandlung Deutschlands seit der Konferenz von Quebec im September 1944 die offizielle Position der US-Regierung darstellten und daß darüber hinaus deutlich sei, „that in the Potsdam Declaration [...] the three principal Allies were seeking to carry out the objectives of that policy" 82 .

Andererseits ist immer wieder darauf hingewiesen worden, daß es, sobald Morgenthaus Einfluß zum Tragen kam, auch sofort Bestrebungen gab, ihn soweit wie möglich zu unterlaufen ${ }^{83}$, und gerade die Ergebnisse der Konferenz von Potsdam sind in diesem Zusammenhang als der entscheidende Durchbruch interpretiert worden ${ }^{84}$. Während damit der "karthagische" Charakter der die amerikanische Besatzungspolitik definierenden Dokumente nicht geleugnet wird, konzentriert sich diese Argumentation auf einige in der endgültigen Form von JCS 1067 enthaltenen Formulierungen, die - zusammen mit den in Potsdam gefaßten Beschlüssen - eine gewisse Flexibilität bei der Umsetzung dieser Direktive erlaubten ${ }^{85}$.

Auf dieser Ebene ist dann auch nach einem von den R\&A-Arbeiten eventuell ausgehenden Einfluß auf die Formulierung von Richtlinien für die amerikanische Besatzungspolitik bzw. die alltägliche Praxis der Militärregierung zu fragen. Dabei gilt es jedoch wiederum zu berücksichtigen, daß diese R\&A-Arbeiten lediglich Dienstleistungen einer nach Maßstäben der Washingtoner Regierungsbürokratie eher obskuren und reichlich kontroversen neuen Organisation waren, die keinerlei Entscheidungsbefugnisse hatte und ihrem Auftrag nach darauf beschränkt war, den etablierten Behörden zuzuarbeiten. Die in vielen Punkten bestehende Übereinstimmung zwischen den von R\&A vertretenen Positionen und denen des State Department wird vor diesem Hintergrund im allgemeinen dazu führen, daß der Beitrag von R\&A als bestenfalls sekundär eingestuft wird. Selbst wenn man dies als gerechtfertigt betrachten will, kann der Beitrag von R\&A nicht, wie bislang, einfach ignoriert werden. Denn während die Versu-

${ }^{81}$ Vgl. dazu den Bericht Holborns über sein Gespräch mit Hilldring und das entsprechende Kabel an Eisenhower in: NA, RG 226, E 37, b 2, f: Civil Affairs-Miscellaneous Correspondence.

${ }^{82}$ Morgenthau, Germany Is Our Problem, xii.

${ }^{83}$ Siehe dazu z. B. Dorn, The Debate over American Occupation Policy, PSQ 72/4, S. 481-501; sowie Holborn, American Planning of Military Government, in: ders., Germany and Europe, besonders S. 261 ff.; vgl. auch ders., American Military Government, S. 41.

${ }^{84}$ So vor allem Gimbel, American Occupation, S.1-8.

${ }^{85} \mathrm{Vgl}$. in diesem Zusammenhang das ebenda, S.2, zitierte Kabel Clays vom 2.12. 1945: „JCS 1067 as modified by Potsdam has proved workable." Vgl. außerdem JCS 1067/6 vom 26.4. 1945, abgedruckt z. B. in: Documents on Germany under Occupation 1945-1954, S. 12 ff. 
che des State Department, eine drastische Revision von JCS $1067 \mathrm{zu}$ erreichen, zumindest für das erste Nachkriegsjahr auch dann noch als gescheitert angesehen werden müssen, wenn man die in Potsdam gefaßten Beschlüsse als erste Anzeichen einer konstruktiven Deutschlandpolitik verstehen will, läßt sich auf der Ebene, auf der die von R\&A entworfenen Richtlinien angesiedelt waren, für eine gewisse Kontinuität einer von der „vae victis“-Phase kaum beeinflußten amerikanischen Deutschlandpolitik argumentieren. Im einzelnen wohl nicht näher bestimmbar, dürfte sie auch durch die von R\&A ausgearbeiteten Civil Affairs Guides vermittelt gewesen sein, die den Besatzungsoffizieren im Hinblick auf JCS 1067 sicherlich gute Anleitungen für eine „Technik des Umgangs mit nicht bejahten Instruktionen " boten ${ }^{86}$.

Mit ihrem zentralen politischen Anliegen - dem Plädoyer für eine von der Militärregierung möglichst unbehinderte Entfaltung „demokratischer ${ }^{c}$, d.h. tiefgreifende Reformen anstrebender Kräfte und eine diese Kräfte abschirmende bzw. begünstigende Entnazifizierung - sind die von R\&A ausgearbeiteten Civil Affairs Guides jedoch fraglos gescheitert. Doch angesichts der gelegentlich konstatierten, zuweilen nicht ohne gewisse europäische Überheblichkeit als typisch amerikanisch bezeichneten Tendenz, „die Grundwerte der eigenen [. . . Verfassung für den Maßstab einer sinnvollen, guten Ordnung [...] zu halten und dementsprechend diese Grundwerte und andere damit zusammenhängende Sichtweisen politischen Handelns nicht nur zur Grundlage der eigenen Außenpolitik zu machen, sondern darin auch einen der wichtigsten Exportartikel für die gesamte übrige Welt zu sehen ${ }^{487}$, kann freilich der Wert der von R\&A immer wieder unternommenen Versuche, die künftigen Besatzungsoffiziere für andere historisch gewachsene Maßstäbe zu sensibilisieren, kaum hoch genug veranschlagt wer$\operatorname{den}^{88}$.

Daß das Civil Affairs-Programm des War Department trotz seines Charakters als „short-term program“ für eine nur als Übergangslösung konzipierte Militärregierung das umfangreichste Planungsprogramm war, das während des Krieges von amerikanischer Seite entwickelt wurde ${ }^{89}$, dürfte insgesamt allerdings lediglich geeignet sein, die eingangs erwähnte Kritik an der mangelhaften Vorbereitung der amerikanischen Besatzungspolitik zu modifizieren, nicht aber sie grundsätzlich zu entkräften. Die zentralen Fragen der amerikanischen, geschweige denn der alliierten Nachkriegspolitik waren durch dieses Projekt nicht erfaßt, sondern sollten und mußten vielmehr ausgeklammert werden.

${ }^{86}$ Mit dieser Formulierung beschreibt Graml, Zwischen Jalta und Potsdam, in: VfZ 24 (1976), S. $308 \mathrm{ff}$., den von ihm an einer Einzelstudie dargestellten Versuch, die von Washington vorgegebenen Direktiven auf MG-Ebene zu interpretieren; siehe insbesondere S.314; vgl. auch die nachfolgend abgedruckten Dokumente der US Group CC.

${ }^{87}$ Hier aus Czempiel/Schweitzer, Weltpolitik der USA nach 1945, S. 28.

${ }^{88}$ Vgl. dazu Abschnitt IV.6c der JCS 1067 ablösenden Direktive 1779, in dem der Oberbefehlshaber der amerikanischen Besatzungsstruppen am 11.7. 1947 amtlich davon in Kenntnis gesetzt wurde: „Your Government does not wish to impose its own historically developed forms of democracy and social organization on Germany and believes equally firmly that no other external forms should be imposed“; abgedruckt z. B. in: Department of State, Germany 1947-1949, S. 35.

${ }^{89}$ Holborn, American Planning of Military Government, in: ders., Germany and Europe, S. 253. 


\section{Kriegsziele als Hypothek für die Friedensordnung?}

Eine der zentralsten und auch am frühesten aufgeworfenen, letztlich aber während des ganzen Krieges immer wieder ergebnislos diskutierten Fragen der Nachkriegsordnung betraf die territoriale Integrität Deutschlands ${ }^{90}$. Im November 1941 deutete Churchill die von ihm mehrfach vertretene Vorstellung von einer Abtrennung Preußens bereits gegenüber Stalin an, als er in einem Telegramm feststellte, daß es am „Beratungstisch der Sieger" in erster Linie darum gehen müsse, „Deutschland, und insbesondere Preußen, zu verhindern, uns ein drittes Mal anzufallen “91. Knapp einen Monat später unterbreitete Stalin dem britischen Außenminister Anthony Eden bei dessen Besuch in Moskau konkrete Vorschläge für eine Zerstückelung Deutschlands ${ }^{92}$. Damit war Ende 1941 nicht nur das wohl wichtigste Kriegs- oder, wenn man will, Friedensziel der Alliierten formuliert, sondern auch der die deutschlandpolitischen Diskussionen während der Kriegskonferenzen entscheidend prägende Vorschlag zur Verwirklichung dieses Zieles gemacht: Deutschland sollte dauerhaft als eine den Frieden bedrohende Macht ausgeschaltet werden; eine Aufteilung des Reiches in mehrere kleine Staaten schien geeignet, dies zu erreichen und zu sichern ${ }^{93}$.

Damit hatte freilich auch begonnen, was ein Mitglied des vom State Department Anfang 1942 eingerichteten Advisory Committee on Post-War Foreign Policy rückblikkend als die Jagd nach der „Fata Morgana der Zerstückelung“ bezeichnen sollte ${ }^{94}$. Denn die Deutschlandexperten in London und Washington - ebenso wie anscheinend auch ihre Kollegen in Moskau ${ }^{95}$ - bezweifelten, daß sich solche brachiale Methoden

90 Vgl. dazu Schulz, „Dismemberment of Germany“, in: HZ 1987, Bd. 244, S. 29-92.

${ }^{11}$ Churchill, Der Zweite Weltkrieg, Bd. III, 2, S. 180 f.

92 Edens Bericht über seinen Besuch in Moskau findet sich in Churchill, ebenda, S. 294 f., und ausführlicher in Ross, The Foreign Office and the Kremlin, S. $82 \mathrm{f}$., sowie in Edens Memoiren, The Reckoning, S.285ff.

${ }_{93} \mathrm{Zu}$ den Diskussionen über eine Aufteilung Deutschlands Deuerlein, Die Einheit Deutschlands, Bd. I; Graml, Die Alliierten und die Teilung Deutschlands.

94 Mosely, Die Friedenspläne der Alliierten, in: Europa-Archiv, 1950/I, S. 3034; vgl. zur Arbeit des Komitees außerdem Moltmann, Die frühe amerikanische Deutschlandplanung, in: VfZ 1957, S. 241-264, insbesondere S.252 ff.; sowie Department of State, Postwar Foreign Policy Preparation, 1939-1945, S.69ff., und Wala, Winning the Peace, S. $48 \mathrm{ff}$.

95 Vgl. dazu vor allem die während der Moskauer Außenministerkonferenz abgehaltenen Gespräche am 25.10. 1943: FRUS 1943, Vol. I, General, S. 513 ff., 629 ff.; FRUS, Conferences at Cairo and Tehran, S.183-186; insbesondere in Moselys Darstellung scheinen die Außenminister darin übereinzustimmen, daß sich im Hinblick auf die Frage einer Aufteilung Deutschlands eine Diskrepanz zwischen den Empfehlungen von Expertengremien und der Haltung "höchster Regierungsstellen" abzeichnete, vgl. Mosely, Die Friedenspläne der Alliierten, in: Europa-Archiv 1950/I, S. 3035, sowie Holborn, Political Collapse of Europe, S.174f. Zur Haltung Moskaus vgl. auch den OSS-Bericht in FDRL, PSF/Subject, b 168, „Russian Policy Toward Germany“, 8.7. 1944: "Soviet circles [in the US] state that a dismemberment of Germany will not meet with Moscow's approval.“ Außerdem: Fischer, Sowjetische Deutschlandpolitik im Zweiten Weltkrieg; Mastny, Russia's Road to the Cold War. - Einigkeit im Hinblick auf diese Frage bestand allerdings auch in den Planungsstäben nicht; so war bspw. Sumner Welles, der in Abwesenheit Außenminister Hulls den Vorsitz im Advisory Committee on Post-War Foreign Policy führte, ein entschiedener Befürworter einer Zerstückelung Deutschlands, vgl. Welles, The Time for Decision, S.336ff.; für die britische Seite vgl. King, Allied Negotiations and the Dismemberment of Germany, in: JCH 16/3 (1981), S.587, und Burridge, Great Britain and the 
längerfristig als politisch sinnvoll erweisen würden. Doch wie sich bald zeigen sollte, konnten in "den fortgeschrittenen Phasen des Krieges [...] fachmännische Theorien nur schwer gegenüber spontanen politischen Willensäußerungen standhalten ${ }^{c 96}$. Trotz der Bedenken ihrer Experten mochten die „Großen Drei“ dieses Thema nicht fallenlassen, ohne sich freilich auch nur annähernd auf eine Teilungskonzeption einigen zu können. Noch auf der Konferenz von Jalta Anfang Februar 1945 war und blieb diese zentrale Frage der Nachkriegsordnung unbeantwortet; letztlich einigte man sich nur darauf, ein "Dismemberment Committee" einzusetzen, das sich eigens mit dieser Problematik befassen sollte, dies aber nicht ernsthaft tun brauchte, weil die Sowjetunion Ende März durchblicken ließ, daß sie nicht an einer Zerstückelung Deutschlands interessiert sei"

Als Historiker - nicht mehr als R\&A-Mitarbeiter - hat Hajo Holborn den "Großen Drei“ später ein schlechtes Zeugnis ausgestellt, wenn er die Protokolle ihrer deutschlandpolitischen Diskussionen als „painful reading“ bezeichnete. Holborn kritisierte in diesem Zusammenhang nicht nur das Festhalten der "Großen Drei“ an ihren Zerstükkelungsplänen, sondern bemängelte auch, daß die von ihnen formulierten Vorschläge zu deren Durchführung so ganz offensichtlich „not [...] on familiarity with German history and German conditions" gründeten ${ }^{98}$. Kaum weniger schwer dürfte allerdings gewogen haben, daß die vorrangige Erörterung von Zerstückelungsplänen auf der Ebene der "Großen Drei“ einen bedenklichen Mangel an politischem Sinn und Verständnis dafür bezeugte, wie Kriegsziele in Friedensziele zu übersetzen seien. Denn daß eine Zerstückelung Deutschlands von den Siegermächten nur gewaltsam durchgesetzt und auf absehbare Zeit auch nur gewaltsam aufrechterhalten werden konnte, war kaum zu bezweifeln; daß auf dieser Basis eine stabile Friedensordnung für Europa aufgebaut werden könnte, war dagegen kaum zu hoffen.

Daß die "Großen Drei“ diesen Gedanken dennoch nicht aufgeben wollten, blieb schließlich nicht ohne Folgen für die Arbeit der Planungsstäbe. Denn solange diese zentrale Frage nicht gelöst war, mußten die Planer mit so vielen „Unbekannten“ rechnen, daß konkrete Planungen für die Nachkriegspolitik kaum möglich waren. Gleichzeitig setzten die Zerstückelungspläne der „Großen Drei“ aber auch einen drastischen Kontrapunkt zu den maßvollen Programmen der Deutschlandexperten, indem sie „Vansittartism“99 sozusagen hoffähig machten und letztlich einer Verschärfung der Nachkriegspolitik gegenüber Deutschland den Weg bereiteten. Damit verwickelte sich die alliierte Deutschlandplanung zunehmend in Widersprüche, denn viele der im letz-

Dismemberment of Germany, in: International History Review III/4 (1981), S. $565 \mathrm{ff}$. Zur britischen Deutschlandplanung insgesamt Kettenacker, Krieg zur Friedenssicherung.

${ }^{96}$ Moltmann, Die frühe amerikanische Deutschlandplanung, in: VfZ 5 (1957), S.257f.; für die britische Seite vgl. Rothwell, Britain and the Cold War 1941-1947, S.41; ähnlich auch Burridge, Great Britain and the Dismemberment of Germany, in: International History Review III/4 (1981), S. 569.

97 Vgl. dazu Geyer, Deutschland als Problem der sowjetischen Europapolitik, in: Foschepoth (Hrsg.), Kalter Krieg und Deutsche Frage, S. 50-65.

98 Holborn, Political Collapse of Europe, S. $174 \mathrm{f}$.

99 Der Ausdruck "Vansittartism“ wird hier in dem von Dorn definierten Sinn einer "school of thought" zu Fragen der alliierten Deutschlandpolitik in der Nachkriegszeit benutzt, vgl. Dorn, American Occupation Policy, in: PSQ 72/4 (1957), S. 484 f. 
ten Kriegsjahr diskutierten Maßnahmen zur dauerhaften Eliminierung des deutschen Kriegspotentials ließen sich kaum noch mit den Visionen einer umfassenden Friedensordnung vereinbaren, wie sie schon in der Atlantik-Charta aufgeschienen waren und wie sie später im Rahmen der Vorbereitungen für die Gründung der Vereinten Nationen weiterentwickelt wurden ${ }^{100}$.

R\&A fand so in bezug auf Fragen der Nachkriegspolitik noch ein weites Betätigungsfeld vor, als sich die im Rahmen des Civil Affairs-Programms anfallenden Arbeiten für das War Department im Frühsommer 1944 ihrem Abschluß näherten. In R\&A ging man davon aus, daß die Abteilung angesichts des in Washington immer bestehenden Bedarfs an "first-class political research on foreign countries" gute Chancen habe, diese "Marktlücke“ mit entsprechend anspruchsvollen Arbeiten zu füllen ${ }^{101}$. Auch wenn R\&A-Mitarbeiter gelegentlich bezweifelten, daß wissenschaftlich kompetente Analysen in der Washingtoner Bürokratie tatsächlich allgemein geschätzt wurden, glaubte man in der Abteilung doch, daß es eher ein "Vermarktungsproblem" sei, wenn die für die Formulierung der US-Außenpolitik zuständigen Behörden R\&A nicht regelmäßig mit den von ihnen benötigten Studien beauftragten.

Wie abteilungsinterne Richtlinien zur Ausarbeitung politischer Studien ausführten, konnte R\&A durchaus hoffen, Gehör in den bedeutendsten Regierungsbehörden zu finden, ja man sah gar die Möglichkeit „to influence policy“. Voraussetzung dafür sei allerdings, „[that] those who decide policy have confidence in the quality and integrity, or straight-forward character, of our work". Gleichzeitig war man sich in R\&A im klaren darüber, daß die Abteilung nicht als „pressure group“ auftreten dürfe - „no matter how strongly we may believe we are ,right“". Denn, wie man wohl ganz richtig erkannte: „In contrast with the readers of most of our economic and topographic reports, the readers of our political reports commonly have a prior conviction on the subject under discussion, convictions based on considerable knowledge of the material.“ Da R\&A-Mitarbeiter nicht erwarten könnten, daß ihre Schlußfolgerungen unkritisch akzeptiert würden, sei es besonders wichtig, nachrichtendienstliche Berichterstattung und Analyse einerseits und politische Empfehlungen andererseits streng voneinander zu trennen. Berichte müßten völlig unparteiisch und informativ, nicht argumentativ gehalten sein; alle Empfehlungen - „whether explicit or veiled“ - seien zu vermeiden. Bei der Formulierung von politischen Empfehlungen sei deutlich zwischen Information einerseits und der Interpretation sowie den Schlußfolgerungen des Verfassers andererseits zu unterscheiden. Grundsätzlich müßten sich die R\&A-Mitarbeiter um strikte Objektivität bemühen, und schon ihr Stil müsse diesem Ideal entsprechen:

${ }^{100}$ Zur Bedeutung ideeller Überzeugungen für die amerikanische Außenpolitik vgl. Schwabe, Die Ära Roosevelt, in: Schulz (Hrsg.), Die Große Krise der dreißiger Jahre, S. 200-214. Allgemein zur US-Außenpolitik unter Roosevelt: Dallek, Franklin D. Roosevelt and American Foreign Policy.

101 Dazu und zum Folgenden NA, RG 226, E 1, b 3, „Draft of proposed guide to preparation of political reports", [o.D.], sowie ebenda, b 9, f: Political Reports (Preparation of): „Guide to Preparation of Political Reports", 5.5. 1944, und NA, RG 226, E 37, b 2, f: Civil Affairs-Research and Analysis Civil Affairs Committee, Protokoll der Sitzung am 31.7. 1944. Die Klage über die mangelnde Anerkennung der von R\&A geleisteten Arbeit findet sich in NA, RG 226, E 1, b 3, f: Europe-Africa Division 1944, „Observations on the Use of Social Scientists in $R \& A^{“}$, 3.3. 1944. 
„Generally speaking, ,should' and ,ought' - not to mention ,must' are taboo. Value adjectives and nouns are to be avoided no matter how much they may appear to add literary quality. "102 Doch auch indirektere Wertungen - wie etwa die einseitige Auswahl von Informationen, die vor allem die Ansicht des Verfassers illustrierten - seien bewußt zu vermeiden.

Darüber hinaus hinge die Brauchbarkeit der in R\&A ausgearbeiteten Studien aber auch von ihrer Gestaltung $a b$, denn alle potentiellen Interessenten stünden unter groBem Zeitdruck und sähen sich sowieso schon mit enormen Mengen von Papieren konfrontiert. Dem müßten R\&A-Arbeiten Rechnung tragen; jede Studie sollte deshalb eine Zusammenfassung enthalten, in der genau darzulegen sei, welche Fragestellungen untersucht würden, was die wichtigsten Punkte der Darstellung seien und welche Schlußfolgerungen daraus gezogen würden. Dem Rest des Berichts komme lediglich die Aufgabe zu, diese Zusammenfassung zu illustrieren bzw. zu belegen ${ }^{103}$.

Angesichts der stets schwierigen Arbeitsbedingungen in R\&A bezeugen diese Richtlinien bemerkenswertes Engagement. Dabei reflektieren sie in ihrer fast schon strategisch zu nennenden Ausrichtung einerseits hochgespannte Erwartungen im Hinblick auf die Möglichkeiten der Abteilung, mit ihren Arbeiten einen Beitrag zur Formulierung der amerikanischen Nachkriegspolitik zu leisten, andererseits aber auch das Bewußtsein, daß ein auf diese Ebene abzielender Beitrag keineswegs von vornherein erwünscht war und auch nicht ohne weiteres akzeptiert werden würde. Der grundsätzliche Optimismus, sich durch qualitativ hochstehende Arbeiten bei wichtigen Regierungsbehörden Gehör und Gewicht verschaffen zu können, war allerdings anscheinend nicht gänzlich unbegründet. Seit Anfang 1944 verzeichnen die von R\&A geführten "Monthly Progress Reports“ zahlreiche Arbeitskontakte mit dem State Department, sprechen gar von enger Zusammenarbeit, und erwähnen immer wieder eine steigende Nachfrage an R\&A-Studien ${ }^{104}$. Zudem übernahmen einzelne R\&A-Mitarbeiter auf Anfrage des State Department zunächst Teilzeitpositionen dort und wechselten schließlich ganz zum State Department über, was R\&A ebenfalls „an outlet for substantial work" verschaffte ${ }^{105}$. Daneben blieb das War Department auch nach Abschluß der Arbeiten am Civil Affairs-Programm einer der Hauptabnehmer für R\&A-Arbeiten, die JCS forderten ebenfalls häufig R\&A-Studien an, und auch zahlreiche andere Washingtoner Behörden nahmen die Dienste von R\&A in Anspruch.

${ }^{102}$ Siehe hierzu auch das scharfe Selbstkritik enthaltende R\&A- „Style Sheet" in NA, RG 226, E 1, b 2, f: Administrative Office.

${ }^{103}$ Dazu auch NA, RG 226, E 1, b 2, f: State Department 1944/1945, „The Relation of R\&A Papers to State Department Policy“, 16.5. 1945.

104 NA, RG 226, E 42: Research and Analysis Branch, Europe-Africa Division, Monthly Progress Reports, Sept. 1943 - June 1945.

105 NA, RG 226, R\&A-History, (Economic Subdivision), S.35/36f. Die R\&A-History nennt in diesem Zusammenhang den Erdölexperten Walter Levy und den Wirtschaftswissenschaftler Emile Despres; Anfrage des State Department nach Mitarbeit von Despres in NA, RG 226, E 1, b 2, f: State Department 1944/1945. Seit Herbst 1944 arbeitete auch Edward Mason als Berater für das State Department (Department of State, Postwar Foreign Policy Preparation, S. 224), später fungierte er - laut Katz, Foreign Intelligence, S.131 - als Deputy Assistant Secretary für Außenhandelspolitik und Kriegsschulden und als Wirtschaftsberater der US-Delegation während der Moskauer Konferenz 1947. 
Anders als bei den R\&A-Arbeiten zum nationalsozialistischen Deutschland, die offenbar häufig auf abteilungsinterne Initiative zurückgegangen waren und sich, sofern sie politische Analysen darstellten, auch nicht nach den unmittelbar drängenden Erfordernissen des Krieges hatten richten müssen, waren die Themen und Fragestellungen nun meist vorgegeben - wenn nicht tatsächlich von den Auftraggebern, so vom Prozeß der Nachkriegsplanung. Dementsprechend wurden die zentralen Fragen der Nachkriegspolitik meist unter ganz bestimmten Gesichtspunkten untersucht, und insofern erforderten diese Arbeiten - sehr viel mehr als die Analysen des nationalsozialistischen Deutschland, die oft unverkennbar die Handschrift der Central Europe Section trugen - Zusammenarbeit mit den fachlich spezialisierten R\&A-Abteilungen, insbesondere der Economics Division. Dabei blieb R\&A jedoch stets bestrebt, eine zu starke Einengung des Gesichtsfeldes zu vermeiden, und immer wieder verwiesen R\&AStudien darauf, daß kaum eine Frage der Nachkriegspolitik isoliert betrachtet werden konnte. Letztlich führte dies nicht selten dazu, daß die entsprechenden Studicn in ihren Aussagen eher vage schienen und es - wohl ganz im Sinne der oben erwähnten Richtlinien - vermieden, eindeutig Stellung zu beziehen. Statt dessen wurden verschiedene Möglichkeiten durchgespielt bzw. auf ihre Konsequenzen hin untersucht, und es blieb häufig dem Leser überlassen, konkrete Schlußfolgerungen selbst zu ziehen.

Freilich verstand es R\&A, diese Schlußfolgerungen durch Anlage und Argumentation der jeweiligen Studie in eine ganz bestimmte Richtung zu lenken. Denn sosehr R\&A um Objektivität bemüht war, so sehr war man in der Abteilung eben auch davon überzeugt, politische Vernunft und Sachargumente auf seiner Seite zu haben, wenn man für den Aufbau einer an den Prinzipien der Atlantik-Charta orientierten Friedensordnung plädierte. Bereits in den Analysen zu den Grundlagen und Herrschaftsmechanismen des NS-Regimes war deutlich geworden, daß man in R\&A den Aufbau einer globalen Friedensordnung als übergreifenden Gesichtspunkt aller deutschlandpolitischen Überlegungen betrachtete. Auch die grundlegenden Züge der später von R\&A vertretenen deutschlandpolitischen Konzeptionen waren in diesen Arbeiten schon erkennbar. Besonders in der Studie zur „Relation Between Aggression and Business Structure in Germany “106 war - in deutlicher Anlehnung an die von Neumann in Behemoth formulierten Überlegungen - eine Deutschlandpolitik skizziert worden, die darauf abzielte, den Einfluß der Schwerindustrie auf die deutsche Politik als Vorbedingung für einen dauerhaften Frieden zu eliminieren, Autarkiebestrebungen durch die Einbindung der deutschen Wirtschaft in den europäischen bzw. internationalen Markt entgegenzuwirken und schließlich über eine Demokratisierung der wirtschaftlichen, politischen und gesellschaftlichen Strukturen Deutschlands eine Stabilisierung zu erreichen.

Während es die Arbeitsbelastung durch das Civil Affairs-Programm R\&A zwischen Herbst 1943 und Frühjahr 1944 nicht erlaubt hatte, umfassende Studien zu den zentralen Fragen der Nachkriegspolitik auszuarbeiten, hatte die Formulierung der Richtlinien für die Civil Affairs Guides trotz der vom War Department verlangten politischen Abstinenz doch immer wieder eine zumindest rudimentäre Definition politischer Grundpositionen erfordert. Auch dabei war wieder deutlich geworden, daß

${ }^{106}$ NA, RG 59, R\&A 1145, 25.8. 1943, siehe dazu Kap. IV., 2. Teil. 
R\&A in einer tiefgreifenden Demokratisierung Deutschlands die beste Garantie für Stabilität und Frieden sah. Anders als bei den offenbar häufig auf abteilungsinterne Initiative ausgearbeiteten Analysen zum nationalsozialistischen Deutschland war R\&A im Rahmen der Arbeiten für das Civil Affairs Programm allerdings gezwungen gewesen, bei der Formulierung der eigenen Positionen die Vorstellungen anderer Regierungsbehörden, insbesondere die von War Department und State Department, zu berücksichtigen. Insgesamt hatte sich dabei abgezeichnet, daß R\&A in vielen grundsätzlichen Fragen der Deutschlandpolitik weitgehend mit dem State Department übereinstimmte, denn obwohl R\&A manche Akzente setzte, die nicht die Billigung dieses Ministeriums finden mochten, entsprachen die in der oben erwähnten Analyse zur „Relation Between Aggression and Business Structure in Germany" skizzierten deutschlandpolitischen Vorstellungen ebenso wie die während der Arbeit am Civil AffairsProgramm formulierten Empfehlungen im wesentlichen den vom State Department vertretenen Konzeptionen ${ }^{107}$.

Damit war die grundsätzliche Haltung der R\&A-Branch in den zentralen Fragen der Nachkriegspolitik bereits vorgezeichnet: Der Aufbau einer stabilen Friedensordnung mußte nach Ansicht von R\&A das vorrangige Ziel der Nachkriegspolitik sein, wobei die Verwirklichung dieses Ziels im Verständnis von R\&A Maßnahmen ausschloß, deren Durchsetzung und Einhaltung nur durch Zwang und dauerhafte Überwachung bzw. Intervention gewährleistet werden konnte. Auf der Basis dieser Prämissen entwickelte R\&A ein Set von Kriterien und Argumenten, das in allen Arbeiten zur Deutschlandpolitik der Nachkriegszeit als Folie für die Beurteilung der jeweils diskutierten Maßnahmen diente.

Die dabei formulierten Konzeptionen lassen sich exemplarisch anhand einiger im ersten Halbjahr 1944 ausgearbeiteter Positionspapiere nachzeichnen. Ein von den leitenden Mitarbeitern der Abteilung ausgearbeitetes Memorandum zu den „American Security Interests in the European Settlement" kann hierbei als Grundsatzpapier für die von R\&A vertretenen Positionen angesehen werden ${ }^{108}$. In diesem Memorandum wurde ausgeführt, daß das amerikanische Interesse an der in Europa aufzubauenden Nachkriegsordnung „primarily one of security“ sei, wirtschaftliche Interessen seien dagegen lediglich "of distinctly secondary importance". Sicherheit wurde in diesem Zusammenhang im Sinne einer stabilen Friedensordnung in Europa verstanden, wobei R\&A

107 Vgl. „The Political Reorganization of Germany“, 23.9. 1943, in: Department of State, Postwar Foreign Policy Preparation, S.558ff.; siehe außerdem die Denkschriften in FRUS 1944 I, S. 302-325, sowie FRUS, Potsdam 1945 I, S.456ff., $586 \mathrm{ff}$.

${ }^{108}$ NA, RG 226, E 1, b 7, f: Director's Committee 1944-1945, R\&A an Donovan, 17.7. 1944, siehe außerdem die von Paul A. Baran verfaßte Denkschrift „Germany and the Post-War Balance of Power" vom 16. 5. 1944 (ebenda), sowie einen Bericht zu „British Official and Unofficial Attitudes Towards Post-War Germany" vom Mai 1944 (ebenda) und NA, RG 226, E 74, b $2 f$, Germany-Peace, insbesondere das gegenüber Großbritannien überaus mißtrauische Positionspapier des Londoner R\&A-Büros zur „Three-Power Co-Operation and the Occupation of Germany", [o.D.]; vgl. dazu auch Katz, Foreign Intelligence, S. $125 \mathrm{ff}$. - Interessant wäre eventuell ein Vergleich der von R\&A entwickelten Konzeptionen mit den an der New School for Social Research bzw. am Institute of World Affairs erarbeiteten Positionen, vgl. dazu Krohn, Nachkriegsplanungen, in: Koebner/Sautermeister/Schneider (Hrsg.), Deutschland nach Hitler, S. $127 \mathrm{ff}$.; vgl, auch die bei Wala, Winning the Peace, S.48ff. erwähnten „War and Peace Studies". 
davon ausging, daß die Interessen der USA in Europa insofern eher indirekter Natur seien, als daß sie durch ein stabiles, weder von Großbritannien noch der Sowjetunion dominiertes Europa bereits gewahrt wären. Den USA mußte deshalb nach Ansicht von R\&A vor allem daran gelegen sein, die Spaltung Europas in eine britische und eine sowjetische Einflußsphäre zu verhindern: „governments not exclusively oriented to either Russia or Britain are the sine qua non for the avoidance of very serious friction between these two powers, and thus for the security of Britain (and the United States)." Diese „Neutralität“ Europas konnte nach Ansicht von R\&A nur durch eine Intensivierung der innereuropäischen Beziehungen erreicht werden; längerfristig bedeute dies „some form of European union not directed against either Britain or Russia, but integrated with both".

Dabei war Deutschland nach Ansicht von R\&A „[the] crux of the European settlement". Zum einen gelte es auch und vor allem in Deutschland, eine Spaltung in eine britische und eine sowjetische Einflußzone zu verhindern. Längerfristig sei deshalb die Einbindung Deutschlands in die europäische Wirtschaftsstruktur unabdingbar, was nach Ansicht von R\&A durchaus damit zu vereinbaren war, daß Deutschland in der unmittelbaren Nachkriegszeit für den von ihm begonnenen Krieg zur Verantwortung gezogen werden sollte, denn, so argumentierte R\&A: „Terms imposed upon Germany, no matter how harsh, will be compatible with the aim of integrating Germany into Europe, if the terms can be and are executed within a reasonably short period, if such terms do not provide for permanent political, territorial or economic disablement, and if they are progressively relaxed when peaceful, democratic forces become ascendant in Germany." Gleichzeitig warnte die Abteilung: „To go further, however, by attempting permanently to impoverish Germany, or to partition her, would be to defeat our own aims of an inherently stable and peaceful European settlement."

Nach Ansicht von R\&A war nämlich die Vorstellung, „[that] a peaceful and prosperous Europe is possible with a permanently prostrate or divided Germany [...] one of the misconceptions common in current discussions of the European settlement". Die Forderung nach einer Reduzierung der deutschen Wirtschaft auf den landwirtschaftlichen Bereich wurde als unrealistisch und unsinnig abgelehnt. Statt dessen plädierte R\&A für ein „economic and political program designed to furnish a real basis for an enduring peace " 109 . Unverzichtbare Elemente dieses Programms waren nach Ansicht der Abteilung: „a. The political and social reconstruction of Germany for the purpose of eliminating its aggressive elements; $b$. The eventual restoration of Germany to an equal place in the society of nations; $c$. The establishment and maintenance of unity of policy and interest among the great powers based upon the gradual elimination of economic and political conflicts of interest."

Der entscheidende Punkt dieses Programms wird durch die säuberliche Auflistung seiner einzelnen Elemente allerdings eher in den Hintergrund gedrängt: daß nämlich der allmähliche Abbau von Interessenkonflikten zwischen den drei Mächten erstmals im gemeinsam besetzten Deutschland eingeübt werden mußte. In dem oben zitierten Memorandum zu den "American Security Interests in the European Settlement“ kam dieser Gedanke etwas deutlicher zum Ausdruck, wenn R\&A die Vorstellung, „[that] the vital

109 NA, RG 59, R\&A 1890.1, „Problems of German Disarmament“, [Preliminary Draft for Discussion and Review], 24.3. 1944. 
issues dividing the great powers can be settled through the mechanism of an international organization" ebenfalls als eine der in Diskussionen um die europäische Nachkriegsordnung gängigen "misconceptions“ zurückwies und argumentierte, daß eine funktionsfähige internationale Sicherheitsorganisation nur als Ergebnis, nicht aber als Voraussetzung befriedigender Konfliktlösungen zwischen den Großmächten denkbar sei ${ }^{110}$. Insofern betrachtete R\&A Deutschland gewissermaßen als Testfeld für die alliierte Zusammenarbeit, und gerade deshalb galt es im Verständnis der Abteilung in besonderem Maße, in Deutschland die Schaffung von konfliktträchtigen Situationen zu vermeiden.

Nach Ansicht von R\&A war allerdings schon in der seit Anfang 1944 in der European Advisory Commission (EAC) ${ }^{111}$ diskutierten Aufteilung Deutschlands in Besatzungszonen ein bedrohliches Konfliktpotential angelegt. Die Aufteilung Deutschlands in gewissermaßen autonome, nämlich jeweils einer Besatzungsmacht unterstehende Zonen, war erstmals im Frühjahr 1943 im Rahmen militärischer Planungen für den "Notfall“ eines baldigen Zusammenbruchs Deutschlands vorgeschlagen worden ${ }^{112}$. Sowohl auf britischer wie auf amerikanischer Seite hatte es allerdings bald Stimmen gegeben, die davor warnten, daß eine Aufteilung Deutschlands in separate Besatzungszonen zur Schaffung von Einflußsphären führen könne. Als Alternative wurde eine gemeinsame alliierte Besetzung Deutschlands durch gemischte Truppenverbände zur Diskussion gestellt. Das für diese Konzeption angeführte Argument - daß sie nämlich die Kooperation der Alliierten notwendig mache bzw. sie geradezu erzwinge - konnte freilich ebensogut als Gegenargument verwendet werden, und angesichts der bei dieser Besatzungsform außerdem zu erwartenden enormen verwaltungstechnischen Probleme setzte sich der Vorschlag, Deutschland in drei, jeweils einer Macht unterstehende Besatzungszonen aufzuteilen, bald durch.

Auch in R\&A hatte man diese Diskussion im Rahmen der abteilungsinternen Vorbereitungen für die Arbeit an den Civil Affairs Guides geführt ${ }^{113}$ und war zu dem Ergebnis gekommen, "that the weight of argument favors [.. . ] a combined determination of national policy questions coupled with the assignment of responsibility for police and certain other types of local administration to occupying authorities in separate zones". Voraussetzung sei allerdings, daß sich die Alliierten möglichst frühzeitig über grundsätzliche Fragen der Besatzungspolitik einigten. Falls eine solche Einigung nicht zustande käme, bliebe schließlich nur die im Urteil von R\&A höchst bedenkliche Aufteilung in separate Besatzungszonen, „[which] would have far-reaching consequences [...] for the relations among the occupying powers and [...] would involve a grave

110 NA, RG 226, E 1, b 7, f: Director's Committee 1944-1945, R\&A an Donovan, „American Security Interests in the European Settlement", 17.7. 1944.

111 Die Einsetzung der EAC als Beratungsgremium der drei Mächte (GB, USA, SU) war auf der Ende Oktober 1943 in Moskau stattfindenden Außenministerkonferenz beschlossen worden: FRUS 1943, Vol. I, General, S. 756 f.

112 Vgl. dazu Sharp, The Wartime Alliance, S. $29 \mathrm{ff}$.

113 Siehe die Unterlagen in NA, RG 226, E 1, b 1, f 8; die nachfolgenden Zitate aus "Proposed Outline for the Organization of Allied Military Government in Germany “, [o.D., wahrscheinlich September 1943], und „Military Occupation and International Control of Germany“, 22.9. 1943. Bei diesen Unterlagen handelt es sich anscheinend um abteilungsinterne Arbeitspapiere, die wahrscheinlich als Grundlage für die Diskussionen um eine R\&A „Branch line“ (s.o. V., 1. Teil) dienten. 
threat to the future peace and stability of Europe“. R\&A ging zwar davon aus, daß es Großbritannien und den USA gelingen würde, sich über eine Koordination ihrer Besatzungspolitik zu verständigen, glaubte aber, es sei „reasonably certain that Russia would be guided by principles sharply at variance with those of the western powers". Die USSR-Division hatte in diesem Zusammenhang ein - wie sich erweisen sollte recht zutreffendes Szenarium entworfen: „Exclusive occupation and control of a zone in eastern Germany by Soviet Russia, and of a zone or zones in western Germany by the United States and Great Britain, would provide the maximum of motive and of opportunity for emphasis on the differences between the Soviet system and our own, and for competitive development, in opposite directions, east and west of the zone line. A joint American-British-Russian authority for Germany as a whole would hardly be able to check the divisive tendencies that might lead in the long run to the complete and open disrupture of the Allies. "114

Dies war freilich genau das System, auf das sich die Alliierten in der European Advisory Commission im ersten Halbjahr 1944 einigten und das sie durch das sogenannte Zonenprotokoll vom 12.September 1944 und das Zusatzabkommen am 14. November 1944 festschrieben ${ }^{115}$. R\&A hielt an den im Herbst 1943 in abteilungsinternen Papieren formulierten Bedenken gegenüber dieser Regelung fest, wobei die Probleme und Konfliktpotentiale, die nach Ansicht der Abteilung in dieser Struktur der alliierten Besetzung und Administration Deutschlands angelegt waren, mit einer Offenheit thematisiert wurden, die angesichts der zunehmend vorsichtigen, wohl an dem oben angesprochenen „Guide to Preparation of Political Reports“ orientierten Formulierungen vieler anderer R\&A-Arbeiten auffällt. So wurde in einer umfangreichen Studie zu den „Economic Characteristics and Interdependence of the Possible Zones of Occupation in Germany"116 schon einleitend ohne Umschweife ausgeführt: „The Allied division

${ }^{114}$ NA, RG 226, E 1, b 1, f 8, "Military Occupation and International Control of Germany", 22.9. 1943 (USSR Division, G.T. Robinson an William Langer).

115 FRUS, Malta and Yalta, S.118ff. Das Zonenprotokoll war am 12.9. 1944 allerdings noch unvollständig unterzeichnet worden, da sich Briten und Amerikaner nicht einigen konnten: beide wollten den ökonomisch wichtigen und wegen seiner Verkehrsverbindungen interessanten Nordwesten Deutschlands, keiner die kleinste und wirtschaftlich unbedeutende Zone im Südwesten. Vor dem Hintergrund dieser Kontroverse diskutierte eine R\&A-Studie die „Relative Desirability of North-western and Southern Germany as a Zone of American Military Occupation" (NA, RG 59, R\&A 2403, 29.7. 1944); außerdem: NA, RG 59, R\&A 2431, „Problems of Military Occupation in Certain Parts of Germany", 31.7. 1944; NA, RG 59, R\&A 2588 Vol. I, „German Post-Surrender Reactions to the United States in Southern Germany“, 2.10. 1944. Weitere R\&A-Studien, Handbücher etc. zu Besatzungszonen: NA, RG 59, R\&A 1757, "Central Industrial Region of Germany“, 4.8. 1944, (Handbuch mit knapp 600 Seiten); NA, RG 59, R8A 2332 „South Germany“, 22. 9. 1944, (Handbuch mit etwa 1500 Seiten, das alle erdenklichen Bereiche - von wirtschaftlichen, sozialen und kulturellen Aspekten bis hin zu Stuttgarts Abwassersystem - behandelt und sich später bei den Besatzungstruppen größter Wertschätzung erfreute, vgl. dazu NA, RG 226, E 1, b 1; NA, RG 226, E 42, b 1, R\&A/EuropeAfrica Division, Progress Report für Mai 1945).

116 NA, RG 59, R\&A 2673 A, 3. 8. 1945, Entwürfe bzw. Einzelstudien 2673.1-5 zwischen Januar und März 1945 ausgearbeitet; eine ähnliche Studie („Economic Features of the German Zones of Occupation“) wurde im Juni 1945 auch vom State Department angefordert und sollte offenbar dem Präsidenten für die Potsdamer Konferenz vorgelegt werden, vgl. NA, RG 226, E 42, b 1. - Außerdem: NA, RG 59, R\&A 2675, „Estimated 1 January Population by Consumer Groups of the Possible Zones of Occupation in Germany“, 13.4. 1945. 
of Germany into zones of occupation will raise many serious economic problems." R\&A begründete diese Voraussage vor allem unter Hinweis darauf, daß Deutschland zu den am stärksten zentralisierten Ländern der Welt gehöre und, bei ausgeprägter regionaler Spezialisierung, hoch industrialisiert sei. Eine der dringlichsten und wichtigsten Aufgaben der alliierten Besatzungsbehörden müsse deshalb die Entwicklung eines gut funktionierenden Systems für den Austausch von Gütern zwischen den einzelnen Besatzungszonen sein, denn, so warnte R\&A: „If provision is not made for such interregional trade the most serious economic consequences will result." Gerade auch im wirtschaftlichen Bereich war die Zusammenarbeit der Alliierten nach Ansicht der Abteilung unerläßlich: „The operation of the German economy with even a moderate degree of efficiency will require a large amount of coordination [...] Even without regard to the efficient operation of the German economy, a very considerable amount of interzonal coordination will be required in the matter of food, fuel supply, transportation, and control of displaced persons if truly chaotic situations are to be avoided."

In Arbeiten für das Civil Affairs-Programm hatte R\&A bereits die Befürchtung geäußert, daß die Aufteilung Deutschlands in Besatzungszonen nicht nur die Gefahr einer politischen Auseinanderentwicklung der westlichen und östlichen Zonen beinhalten, sondern auch eine kaum weniger problematische Auseinanderentwicklung im wirtschaftlichen Bereich mit sich bringen könnte: „Divergent political trends would be matched by divergent economic trends. The Russians would probably attempt as far as possible to integrate their zone into Soviet planned economy in order to facilitate the rehabilitation of Russia's devastated areas. The unity of the German economy would be disrupted [...] a three-zone system of occupation would amount to a virtual political and economic partition of Germany. "117

Vor diesem Hintergrund konnte R\&A die in den Gesprächen der "Großen Drei“ immer wieder diskutierte Option einer Zerstückelung Deutschlands nur ablehnen. Eingedenk der oben erwähnten Richtlinen zur "Preparation of Political Reports“ argumentierte R\&A nun allerdings eher vorsichtig ${ }^{118}$ und wies darauf hin, daß die wichtige Frage, welche wirtschaftlichen Konsequenzen eine Zerstückelung Deutschlands mit sich bringen würde, nur beantwortet werden könne, nachdem grundsätzliche politische Entscheidungen darüber getroffen seien, inwieweit die Wirtschaftsbeziehungen zwischen den nach einer Teilung gebildeten Gebieten Restriktionen unterworfen werden sollten ${ }^{119}$. Wiederum wurde ausgeführt, daß die Interdependenz der einzelnen Regionen aufgrund der hochgradigen Spezialisierung sowohl im Bereich der

117 NA, RG 226, E 1, b 1, f 8, „Proposed Outline for the Organization of Allied Military Government in Germany“, [0.D.].

${ }^{118}$ In einem der Arbeitspapiere für das Civil Affairs-Programm hatte es noch kurz und bündig geheißen: „MG should not endanger Germany's national unity and should oppose the forces of separatism inside and outside. National unity is not a demand of nationalism. It springs from the liberal-democratic tradition. The dismemberment of Germany will not only play into the hands of German nationalism but will also make impossible a democratic and social reconstruction." NA, RG 226, E 1, b 1, f 8, "What is the Purpose of Military Government over Germany?“, 22.9. 1943 (OSS/R\&A: Europe-Africa Division, Psychological Warfare Division, Central Europe Section).

119 Vgl. dazu und zum Folgenden NA, RG 59, R\&A 2237.1, „Economic Consequences of Partitioning Germany“, 10.7. 1944, sowie NA, RG 59, R\&A 2237, „Preliminary Analysis of the Question of a Partition of Germany", 14.7. 1944. 
Landwirtschaft als auch der Industrie sowie aufgrund der Infrastruktur so groß sei, $\mathrm{da} ß$ eine Teilung mit einer völligen wirtschaftlichen Abschottung als überaus problematisch anzusehen sei: „Interruption of the internal trade of Germany would create serious problems not only for the country itself but for the rest of Europe and the world at large. ${ }^{120}$ Insofern bezeichnete R\&A eine rein rechtlich definierte Form einer politischen Teilung, die den wirtschaftlichen Bereich unangetastet ließe, als ideal; gleichzeitig wurde diese Option aber auch als fragwürdig hingestellt, da eine solche Lösung schließlich kaum mehr als eine letztlich irrelevante administrative Geste sein könne.

Im Hinblick auf die Frage, ob die Alliierten sich eventuelle separatistische Bewegungen in Deutschland zunutze machen könnten, um eine gewissermaßen freiwillige und insofern politisch stabile Teilung herbeizuführen ${ }^{121}$, kam R\&A zu dem Ergebnis, daß nicht mit nennenswerten separatistischen Tendenzen zu rechnen sei; falls sie sich überhaupt irgendwo abzeichnen sollten, dann würden sie nach Ansicht der Abteilung lediglich von bestimmten „industrial and financial interests of Western Germany“ begrüßt werden. Diese Kreise würden sich von den Westmächten eine bevorzugte Behandlung erhoffen und in eventuellen separatistischen Tendenzen vor allem „a defense against leftist influences from the Russian zone of occupation" sehen. Jegliche Unterstützung dieser Bestrebungen, so warnte $R \& A$, ,would play into the hands of the very forces that have always opposed a thorough democratization of German society and at the same time would greatly intensify any antagonisms between the Western powers on the one hand and Russia on the other"122.

Die Frage von Gebietsabtretungen konnte als eine weitere Alternative zur Zerstükkelung Deutschlands betrachtet werden, und auch bei der Diskussion dieses Themas befleißigte sich R\&A wieder größter Zurückhaltung. In einem fast 400 Seiten umfassenden „Preliminary Report“ zu den „Consequences of Major Transfers of German Territory " ${ }^{123}$ wurde eingangs ausdrücklich und ausführlich darauf hingewiesen, daß in dieser Studie weder explizite noch implizite Empfehlungen gegeben werden sollten, sondern lediglich die eventuellen militärischen, wirtschaftlichen und politischen Konsequenzen der in Erwägung gezogenen Gebietsabtretungen erörtert werden sollten, wobei es in der Natur dieser Fragestellung läge, daß die problematischen Aspekte betont würden, während Probleme, die ohne die Abtretungen auftreten könnten, eben keine Berücksichtigung fänden.

${ }^{120}$ In diesem Zusammenhang wurde auch darauf hingewiesen, daß schon allein die Entflechtung der deutschen Wirtschaft - etwa die Zerschlagung industrieller „Empires“ wie I. G.Farben sich als überaus schwierig erweisen könnte; hier wurde offenbar an die im Rahmen des Civil Affairs-Programms geführte Diskussion um die Zerschlagung der deutschen Kartelle angeknüpft.

121 Dieser Gedanke war auf der 1. Quebec-Konferenz zwischen Hull und Eden im August 1943 diskutiert worden, vgl. Memoirs of Cordell Hull, Bd. II, S. 1233f.; man hoffte, auf diese Weise die von den „Großen Drei“ gewünschte Teilung ohne die von den Experten erwarteten politischen Probleme bewerkstelligen zu können.

${ }^{122}$ In diesem Zusammenhang wird auch auf einige britische Studien verwiesen, in denen offenbar ebenfalls die Ansicht vertreten wurde, daß kaum mit ernsthaften separatistischen Tendenzen zu rechnen sei.

123 NA, RG 59, R\&A 2914, „Consequences of Major Transfers of German Territory: A Preliminary Report ${ }^{\alpha}$, 1.5. 1945. 
Fast die Hälfte der Studie ist der Beschreibung der geographischen, wirtschaftlichen, politischen und sozialen Verhältnisse in den in Frage stehenden Regionen gewidmet. In der sich anschließenden Erörterung wird die Abtretung der Gebiete östlich der OderNeisse an Polen als relativ unproblematisch dargestellt ${ }^{124}$; eventuelle Gebietsabtretungen im Westen werden dagegen als bedeutend problematischer angesehen. R\&A argumentierte in diesem Zusammenhang vor allem, daß eine entscheidende Schwächung des deutschen Kriegspotentials nur erreicht werden könnte, wenn neben Saar- und Rheinland auch das Ruhrgebiet von Deutschland abgetrennt würde. Dies würde jedoch eine massive Verschlechterung der deutschen Wirtschaftslage zur Folge haben, zudem sei wegen der engen wirtschaftlichen Verflechtung auch mit Problemen in den abgetretenen Gebieten selbst zu rechnen. Vor allem aber werde Deutschland dann ein ständiger Unruheherd sein; die Forderung nach territorialer Revision würde die deutsche Politik dominieren, und die Deutschen würden unter diesen Umständen stets bestrebt sein, Spannungen zwischen den Alliierten für ihre Zwecke auszunutzen.

In all diesen Arbeiten ging R\&A fast selbstverständlich davon aus, daß die „AntiHitler-Koalition" auseinanderbrechen würde, sobald das bindende „Anti“ eliminicrt wäre, daß sich also die Kriegspartner nach Kriegsende als Vertreter grundverschiedener Systeme, Wertvorstellungen und Interessen gegenüberstehen würden. Obwohl R\&A mitnichten der Ansicht war, daß die Interessen Großbritanniens und der USA von vornherein identisch waren, glaubte $R \& A$ doch, daß die beiden westlichen Demokratien in der Lage sein würden, Kompromisse miteinander auszuhandeln. Ob und inwieweit die Sowjetunion in der Nachkriegszeit und insbesondere während der alliierten Besatzungherrschaft in Deutschland zur Kooperation bereit sein würde, war dagegen eine Frage, deren Beantwortung auch den Experten der R\&A-USSR Division trotz der von ihnen entwickelten "uncanny ability to think their way into the Kremlin" - schwerfiel ${ }^{125}$. Dennoch wagten sie die Behauptung, daß die Sowjetunion einer Zusammenarbeit in der Nachkriegszeit grundsätzlich offen gegenüberstehe ${ }^{126}$; R\&A glaubte sogar Anzeichen dafür zu erkennen, daß die Sowjetunion es vorziehe, „to satisfy its interests through cooperation with the Allies". Insofern sei man auf sowjetischer Seite bereit, Kompromisse zu schließen; gleichzeitig habe man sich aber auch darauf

124 Vgl. dazu auch die Zusatzstudie NA, RG 59, R\&A 2914.1, „Consequences of Major Transfers of German Territory: Food and Agriculture“, 21.6. 1945; sowie NA, RG 59, R\&A 2345, „The Food Position of Germany West of the Oder-Neisse Line", 4.8. 1945, eine Analyse der Langzeit-Auswirkungen der Gebietsabtretungen östlich der Oder-Neisse-Linie „as foreshadowed in the Potsdam declaration" auf die Lebensmittelversorgung im restlichen Deutschland. Diese Studie berücksichtigt ausdrücklich nur Langzeitauswirkungen, nicht die Konsequenzen für die unmittelbare Nachkriegszeit, und kommt zu dem Ergebnis, daß diese Gebietsabtretungen nur problematisch würden, wenn Deutschland gleichzeitig der Zugang zu internationalen Märkten erschwert bzw. verweigert würde.

125 So Katz, Foreign Intelligence, S.157; zur Einschätzung der Nachkriegssituation durch die R\&A-USSR Division vgl. ebenda, S. $153 \mathrm{ff}$.

${ }^{126}$ NA, RG 226, E 1, b 1, f 8, "Will the Soviet Union be Willing to participate in a Joint Military Occupation and a Joint Military Government of Germany?", 22.9. 1943 (USSR Division, R\&A-Branch, OSS); vgl. auch den in Roosevelts Unterlagen befindlichen OSS-Bericht vom 8.7. 1944 (FDRL, PSF/Subject, b 168), in dem die Grundzüge der "Russian Policy Toward Germany" aus Gesprächen mit sowjetischen Repräsentanten in den USA entwickelt werden; außerdem: NA, RG 59, R\&A 2669, "Capabilities and Intentions of the USSR in the Postwar Period“, (Preliminary version), 5.1. 1945. 
vorbereitet, die eigenen Interessen im Falle eines Scheiterns der interalliierten Kooperation unabhängig zu verfolgen und zu sichern. In erster Linie werde es der Sowjetunion darum gehen, ihre eigenen Sicherheitsbedürnisse zu befriedigen, und je mehr sie diese als gefährdet ansähe, desto stärker würde sie bestrebt sein, „to establish a wide zone of exclusive control and even to ,sovietize' part or all of this zone". Zwar war R\&A der Meinung, daß der Sowjetunion zumindest in den ersten Nachkriegsjahren grundsätzlich daran gelegen sein mußte, einen ernsthaften Konflikt oder gar eine bewaffnete Auseinandersetzung nach Möglichkeit zu vermeiden, doch betonte R\&A andererseits auch immer wieder das ausgeprägte, weitgehend ideologisch begründete Mißtrauen sowjetischer Politiker im Hinblick auf die Validität und Verläßlichkeit von internationalen Vereinbarungen. Auch und gerade für die Sowjetunion stellte Deutschland deshalb nach Ansicht von R\&A während der Besatzungszeit ein Testfeld für die interalliierte Zusammenarbeit dar.

Als gewissermaßen kleinsten gemeinsamen Nenner für die Deutschlandpolitik der Siegermächte glaubte R\&A die von allen drei Mächten gleichermaßen gewünschte „destruction of Germany's military power“ identifizieren zu können. Folgte man den von R\&A gezogenen „Lessons of World War I“, so erforderte die Durchsetzung dieses gemeinsamen Interesses allerdings auch gleich ein hohes Maß an Kooperation ${ }^{127}$ : „The lesson to be derived from [. . . ] the failure of the first experiment in German disarmament is clear. The permanent enforcement of a disarmament program requires the assurance of continued concerted action among the victorious powers in order to prevent the rebirth of balance of power arrangements from which Germany would be able to profit."

Spätestens seit Finanzminister Morgenthau im September 1944 sein „Program to Prevent Germany from starting a World War III" vorgelegt hatte ${ }^{128}$, war allerdings unübersehbar, daß gerade die Frage, wie eine langfristige Ausschaltung Deutschlands als Militärmacht zu bewerkstelligen sei, zu hitzigen Kontroversen führen konnte. R\&A hatte zu diesem Zeitpunkt bereits in mehreren Studien ausgeführt, daß und warum die Zerschlagung der deutschen Industrie nicht geeignet sei, den Frieden in Europa und der Welt dauerhaft zu sichern. Schon im August 1943 hatte R\&A in der Studie zur „Relation Between Business Structure and Aggression in Germany “ ${ }^{129}$ zwar selbst gefordert, daß der Einfluß der Schwerindustrie auf die deutsche Politik als Vorbedingung für den Aufbau einer globalen Friedensordnung eliminiert werden müsse, gleichzeitig aber eine Zerschlagung der entsprechenden Industrien mit der Begründung abgelehnt, daß die damit erreichte Schwächung der deutschen Wirtschaft insgesamt auch die Wirtschaftsentwicklung anderer europäischer Staaten empfindlich beeinträchtigen würde. In den von R\&A in Vorbereitung für das Civil Affairs-Programm ausgearbeiteten Papieren zu den Aufgaben einer amerikanischen Militärregierung in Deutschland wurde die von „influential groups“ befürwortete Zerschlagung der deutschen Industrie als „not only immoral but actually socially and economically impossible“ beur-

127 NA, RG 59, R\&A 1890, „A Preliminary Discussion of the Future Disarmament of Germany ${ }^{c}$, 11.2. 1944, und NA, RG 59, R\&A 2889, "The Conflict of Political Interests in the Making and Enforcement of German Disarmament Terms, 1918-1935“, 26.4. 1945.

${ }_{128}$ Abgedruckt auf den ersten Seiten von Morgenthau, Germany Is Our Problem.

${ }^{129}$ NA, RG 59, R\&A 1145, 25.8. 1943; s. o. IV., 2. Teil. 
teilt und wiederum argumentiert, daß eine so drastische Schwächung der deutschen Wirtschaft eine Erschütterung des wirtschaftlichen und sozialen Gefüges ganz Europas nach sich ziehen würde ${ }^{130}$. Im Februar 1944 skizzierte ein R\&A-Arbeitspapier schließlich einige grundsätzliche Überlegungen zur künftigen Entmilitarisierung Deutschlands, wobei auch in diesem Papier ein weitreichender Abbau der deutschen Industrie wieder als unvereinbar mit einer Demokratisierung Deutschlands sowie dem wirtschaftlichen Wohlergehen der europäischen Staaten bezeichnet wurde ${ }^{131}$. Zudem gab R\&A zu bedenken, daß in der Diskussion über geeignete Maßnahmen zu einer dauerhaften Eliminierung des deutschen Kriegspotentials auch die Folgen auf andere Bereiche zu berücksichtigen seien, daß also beispielsweise zu überprüfen sei, ob sich diese Maßnahmen mit Reparationsforderungen und den eventuellen territorialen Regelungen vereinbaren ließen. Auch die möglichen Auswirkungen dieser Maßnahmen auf die außenpolitische Ausrichtung Deutschlands gelte es zu bedenken, da es nicht im Interesse Großbritanniens und der USA liegen könne, Deutschland in die Arme der Sowjetunion zu treiben ${ }^{132}$.

Schließlich hatte R\&A in dem bereits erwähnten Memorandum zu den "American Security Interests in the European Settlement ${ }^{\text {“133 }}$ die Vorstellung, ,[that] a peaceful and prosperous Europe is possible with a permanently prostrate or divided Germany", als eine der "misconceptions [...] in current discussions of the European settlement" aufgelistet. Als es Finanzminister Morgenthau dann im September 1944 gelang, diese "misconception" in die deutschlandpolitischen Diskussionen auf höchster Ebene einzubringen, sah sich R\&A freilich gezwungen, dieses Thema erneut aufzugreifen.

Bis zum Jahresende legte die Abteilung so noch mehrere Papiere vor, in denen die wirtschaftlichen und politischen Konsequenzen einer De-Industrialisierung Deutschlands diskutiert wurden ${ }^{134}$. Dabei versuchte R\&A insofern ein wenig zu taktieren, als eingeräumt wurde, daß ein Verbot der deutschen Schwerindustrie als Entwaffnungs-

130 NA, RG 226, E 1, b 1, f 8, "What Is the Purpose of Military Government Over Germany?", 22.9. 1943, vgl. oben V., 1 . Teil.

131 NA, RG 59, R\&A 1890, "A Preliminary Discussion of the Future Disarmament of Germany “, 11.2. 1944; NA, RG 59, R\&A 1890.1, "Problems of German Disarmament", (Preliminary Draft for Discussion and Review), 24.3. 1944.

132 NA, RG 59, R\&A 1885, "Problems and Techniques of the Disarmament of Germany", (First Draft), 10.2. 1944. In dem bereits erwähnten Papier zur "Russian Policy Toward Germany“ (FDRL, PSF/Subject, b 168, 8.7. 1944) wurde allerdings sowieso behauptet, daß Moskau befürchte, „that the United States and Great Britain may be prompted by a ,capitalist policy', attempting to reduce Germany's industrial capacity to a minimum with a view to eliminating an economic competitor. [...] it is Russia's belief that there are serious fundamental reasons which preclude the advisability of destroying German industry“.

133 NA, RG 226, E 1, b 7, f: Director's Committee, R\&A an Donovan, 17.7. 1944.

134 NA, RG 59, R\&A 2503, „An Analysis of the Proposal to Prohibit Heavy Industry in Germany", 29.8. 1944 (daraus das nachfolgende Zitat); NA, RG 59, R\&A 2302, "The Economic Consequences of Depriving Germany of Her Heavy Industry“, 11.11. 1944, eine Zusammenfassung der wichtigsten Ergebnisse dieser Studie wurde in dem von R\&A herausgegebenen "European Political Report“ Ende Dezember 1944 abgedruckt: „Heavy Industry in the German Economy“, European Political Report, 29.12. 1944, Vol. I, No. 41, S.11-15, in: RG 243, E 36, b 96 (155); NA, RG 59, R\&A 2762, „An Analysis of the Proposal to Prohibit Heavy Industry in Germany", 9.12. 1944. 
maßnahme auf den ersten Blick attraktiv erscheinen mochte. Grundsätzlich trug R\&A jedoch wieder die Überzeugung vor, "that the disadvantages are so serious that the plan should be rejected". Erneut wurde damit argumentiert, daß die Eliminierung des deutschen Kriegspotentials durch den Abbau der deutschen Schwerindustrie nur um einen hohen politischen und wirtschaftlichen Preis zu erreichen sei: die massive Beeinträchtigung der deutschen Wirtschaft würde die Etablierung einer demokratischen Regierung in Deutschland erschweren, wenn nicht gar unmöglich machen; die Fähigkeit Deutschlands, Reparationen zu leisten, würde stark beeinträchtigt und insbesondere in hochindustrialisierten Regionen sei zudem mit hoher Arbeitslosigkeit zu rechnen, wovon vor allem die britische Zone betroffen sein würde. Auf Dauer könne keine deutsche Regierung diese Situation akzeptieren. Insofern seien Bestrebungen, die entsprechenden Bestimmungen zu umgehen bzw. zu unterlaufen, gewissermaßen vorprogrammiert, so daß ihre strikte Einhaltung eine ständige Überwachung durch die Alliierten und die Bereitschaft zur Intervention erfordere. Als problematisch könnte es sich nicht zuletzt erweisen, daß die Deutschen die Eliminierung der deutschen Schwerindustrie als Versuch des kapitalistischen Westens sehen könnten, einen Konkurrenten auszuschalten, und im Urteil von R\&A würde davon nur die Sowjetunion profitieren.

Man beließ es in R\&A jedoch nicht dabei, die von Finanzminister Morgenthau vorgeschlagene Politik zu kritisieren, sondern machte sich daran, eine alternative „US Policy Toward the Economic Disarmament of Germany" zu formulieren ${ }^{135}$. Laut R\&A erkannte die US-Regierung, "that economic disarmament [...] must be carefully integrated with a more general US program for the solution of post-hostilities problems and the achievement of a stable and prosperous international organization". Abgesehen von sofortigen Demilitarisierungsmaßnahmen im engeren Sinne wolle die US-Regierung deshalb in der unmittelbaren Nachkriegszeit alle Maßnahmen vermeiden, die die Selbstversorgung Deutschlands mit den wichtigsten Konsumgütern sowie den Beitrag zum Wiederaufbau Europas und die Leistung von Reparationen beeinträchtigen würden. Im Rahmen der auf die langfristige Entmilitarisierung Deutschlands abzielenden Entwaffnungsmaßnahmen würde die Produktion von Waffen und Rüstungsgütern verboten werden. Darüber hinaus befürwortete die US-Regierung - laut R\&A - „a gradual and increasingly comprehensive exposure of German industry and agriculture to the force of foreign competition“, denn, so wurde erklärt, "such action would leave Germany utterly dependent upon foreign countries for the bulk of its food supplies as well as for adequate supplies of petroleum products while allowing her workers to concentrate upon the production of goods in which they have a comparative advantage". Im übrigen begrüße die US-Regierung "the eventual integration of Germany into the type of economic order envisaged by the Atlantic Charter and desires to put no permanent obstacle in the way of German opportunity to share, in due course, in the benefits of a peaceful and expanding world economy".

Das waren wieder die bekannten, von R\&A immer wieder vorgetragenen Argumente und Lösungsvorschläge, die bereits in den Analysen zum nationalsozialistischen Deutschland Gestalt angenommen hatten. Wie ein roter Faden ziehen sich diese Argu-

135 NA, RG 59, R\&A 2469, [o. D.], jedoch offensichtlich nicht vor 1944. 
mente auch durch eine Reihe von Arbeiten, in denen R\&A untersuchte, in welchen Industriezweigen Entwaffnungsmaßnahmen am wirkungsvollsten ansetzen könnten ${ }^{136}$.

Vorausgesetzt wurde in diesen Arbeiten, daß die Produktion von Waffen und Rüstungsgütern im engeren Sinne untersagt sein würde und daß die jeweils diskutierten Restriktionen lediglich zusätzliche Entwaffnungsmaßnahmen darstellen würden. Als wichtigstes Kriterium für diese zusätzlichen Maßnahmen betrachtete R\&A - entsprechend der oben skizzierten „US Policy toward the Economic Disarmament of Germany" - die Forderung, daß die zivile Industrie möglichst wenig beeinträchtigt werden sollte. Dabei war R\&A freilich von vornherein skeptisch, denn da man in der Abteilung der Ansicht war, daß permanente Restriktionen kaum mit dem politischen Fernziel einer Integration Deutschlands in die politischen und wirtschaftlichen Strukturen Europas zu vereinbaren waren und überdies die dauerhafte Überwachung durch die Siegermächte erforderten, sah man den Beitrag solcher Maßnahmen zu einem dauerhaften Frieden als „at best a minor and transitory one“ ${ }^{137}$.

Die Lektüre der entsprechenden Studien war so durchaus geeignet, selbst einen Politiker mit Morgenthaus Überzeugungen zu entmutigen: R\&A wurde nicht müde, die Komplexität der zu berücksichtigenden Faktoren zu beschwören und anzudeuten, wie viele Möglichkeiten ein zur Aggression entschlossenes Deutschland immer noch finden könnte, um die ihm auferlegten Restriktionen zu umgehen bzw. auszugleichen. Nur in dem der Rüstungsindustrie schließlich nahestehenden Bereich des Flugzeugbaus konnte R\&A letztlich eine sinnvolle Ergänzung zum Verbot der deutschen Rüstungsgüterproduktion sehen. Restriktionen in diesem Bereich seien - zusammen mit dem Verbot der deutschen Rüstungsindustrie - geeignet, eine deutsche Wiederaufrüstung zu erschweren, ohne die zivile Industrie zu beeinträchtigen, so daß die deutsche Industrie insgesamt prosperieren könnte. Einmal mehr nutzte R\&A die Gelegenheit zu versichern: „Such recovery is believed to be a logical aim of post-war United Nations policy as a means of assisting the rise of democratic elements in Germany and the restoration of economic prosperity in Europe and the world. "138

In einem Arbeitspapier ${ }^{139}$, das offenbar als Beitrag für ein unter der Leitung der Foreign Economic Administration stehendes Projekt von Studien über die Entwaffnung der deutschen Wirtschaft und Industrie konzipiert war, formulierte R\&A dann noch einmal eine mehrere Seiten umfassende Kritik an den Annahmen, die der Diskussion

${ }^{136} \mathrm{Vgl}$. dazu und zum Folgenden: NA, RG 59, R\&A 2676, „The Elimination of the German Synthetic Rubber Industry as a Disarmament Measure ", 6.12. 1944; NA, RG 59, R\&A 2603, "The Elimination of the German Iron and Steel Industry as a Disarmament Measure", 8.12. 1944; NA, RG 59, R\&A 2677, „The Control of the German Machine-Tool Industry as a Disarmament Measure and Its Economic Consequences for Germany“, 15.3. 1945; NA, RG 59, R\&A 2664, „Oil and German Disarmament", (Preliminary Draft), 26.4. 1945.

137 NA, RG 59, R\&A 1890.1, „Problems of German Disarmament“ (Preliminary Draft for Discussion and Review), 24.3. 1944.

${ }^{138}$ NA, RG 59, R\&A 3605, „Disarmament of the German Aircraft Industry“ (Joint Report of Enemy Objective Unit, Economic Warfare Division of American Embassy and R\&A, OSSLondon), 29.8. 1944.

139 NA, RG 59, R\&A 2664, „Oil and German Disarmament“, (Preliminary Draft), 26.4. 1945; vgl. dazu auch die Unterlagen in NA, RG 226, E 1, b 1, f 39: Inter-Agency Disarmament Committees to Study the Post-Surrender Treatment of German Economics and Industry From the Standpoint of International Security (Frühjahr 1945). 
über geeignete Maßnahmen zur Eliminierung des deutschen Militärpotentials zugrunde lagen. R\&A bezweifelte auch hier wieder grundsätzlich, ob Restriktionen, die über das Verbot der Rüstungsgüterproduktion und des Flugzeugbaus hinausgingen, tatsächlich dazu beitragen würden, erneute deutsche Aggressionen zu verhindern. Zum einen seien die gesamtwirtschaftlichen Konsequenzen solcher Maßnahmen nur schwer abzuschätzen, zumal sie auch von einer Vielzahl politischer Faktoren - etwa territorialen Regelungen oder der Entwicklung der außenpolitischen Beziehungen Deutschlands abhingen; zum anderen stelle sich in diesem Zusammenhang die Frage, wie die Effektivität solcher Maßnahmen überhaupt gemessen werden sollte. Darüber hinaus hielt es R\&A für ,anomalous in the extreme“, daß die Vereinbarungen von Dumbarton Oaks einerseits die Zulassung ehemaliger Kriegsgegner als Mitglieder ,in a family of nations dedicated to the principles of equality and non-discrimination" ins Auge faßten, daß aber andererseits diese Kriegsgegner, insbesondere Deutschland, dauerhaft "subject to discriminatory measures of control in the area of economic disarmament" sein sollten.

Wenn R\&A in all diesen Arbeiten konsequent dafür eintrat, daß die unter dem Eindruck des Krieges diskutierten Maßnahmen zu einer dauerhaften Ausschaltung Deutschlands als Aggressor in der Nachkriegszeit nur mit politischem Augenmaß und Verantwortungsbewußtsein als „Friedensziele“ verwirklicht werden sollten, bedeutete dies keineswegs, daß die Abteilung es ablehnte, Deutschland für den von ihm begonnenen Krieg zur Verantwortung zu ziehen. In dem oben referierten Memorandum zu den "American Security Interests in the European Settlement ${ }^{\text {“140 }}$ hatte R\&A vielmehr die Überzeugung vertreten: „Considerations both of justice and expediency dictate not only the disarmament of Germany, but the imposition of a heavy reparations burden." Grundsätzlich war es nach Ansicht von R\&A angesichts der Produktivität der deutschen Wirtschaft während der Kriegsjahre möglich, "that, if properly managed, such a reparations burden can be exacted while maintaining a minimum subsistence standard of living for the German population". Wie in diesem Zusammenhang ausdrücklich empfohlen wurde, sollten keine Schritte zu einer Verbesserung der Lebensbedingungen in Deutschland unternommen werden „until peaceful and democratic groups have begun to gain ascendancy“. Damit plädierte R\&A wiederum für eine politisch kalkulierte, die aufzubauende Friedensordnung berücksichtigende Umsetzung der aus dem Krieg resultierenden Forderungen: die Deutschland abverlangten Reparationen und die damit verbundenen Belastungen der deutschen Wirtschaft sollten möglichst eindeutig als Erblast des NS-Regimes verstanden werden, die demokratischen Kräfte in Deutschland sollten dadurch sowenig wie möglich kompromittiert werden.

In späteren R\&A-Studien zu den „Problems of German Reparations“ blieb diese politische Dimension allerdings weitgehend unberücksichtigt ${ }^{141}$. Diese offensichtlich von

140 NA, RG 226, E 1, b 7, f: Director's Committee 1944-1945, R\&A an Donovan, 17.7. 1944.

141 NA, RG 59, R\&A 2350, „Problems of German Reparations“, 30.12. 1944 (daraus die nachfolgenden Zitate), diese Arbeit wird auch erwähnt bei Backer, The Decision to Divide Germany, S. 35 f.; vgl. außerdem NA, RG 59, R\&A 2258, „Procurement and Allocation of German Products for the Relief and Reconstruction of Europe“, 6.7. 1944, und NA, RG 59, R\&A 2391, "The Financing of German Import Requirements in the Post-Hostilities Period“, 22.7. 1944. 
der Economics Division ausgearbeiteten Studien beschäftigten sich vorrangig mit den wirtschaftlichen bzw. wirtschaftspolitischen Aspekten der Reparationsfrage und erörterten darüber hinaus vor allem organisatorische und technische Probleme der praktischen Durchführung. Dabei galt es nach Ansicht von R\&A einmal mehr, die „lessons of the last war" zu beherzigen, wobei betont wurde, daß es gelte, die "richtigen" Lehren zu ziehen. Zunächst einmal müßten sich die Empfänger von Reparationen von vornherein darüber im klaren sein, daß sich die Entgegennahme der geforderten Reparationen auf einzelne Wirtschaftsbereiche eher negativ als positiv auswirken konnte. Angesichts dessen, daß die Sowjetunion wahrscheinlich die meisten Reparationen erhalten würde ${ }^{142}$ und als sozialistischer Staat mit Hilfe ihrer planwirtschaftlichen Strukturen entsprechende Vorkehrungen treffen konnte, glaubte R\&A jedoch, daß der Verweis auf eventuelle negative Effekte von Reparationen in den Empfängerländern nur bedingt relevant sei, zumal, wie R\&A argumentierte, auch eine Reihe anderer Empfängerländer wahrscheinlich "semi-socialist" sein würden oder doch ein gewisses Maß an staatlicher Lenkung im wirtschaftlichen Bereich vorsähen. Nach Ansicht der Abteilung konnte auch die deutsche Wirtschaft besser als nach dem letzten Krieg auf die Leistung von Reparationen abgestellt werden, da sie der Kontrolle der Vereinten Nationen unterworfen sein würde, die sich überdies die in Deutschland während des Krieges entwickelten "techniques" zunutze machen konnten, ,to direct the flow of labor and materials into United Nations relief and reconstruction, much as they were used to curtail civilian production and produce armaments".

Die weitverbreitete Auffassung, daß die Erfahrungen nach dem Ersten Weltkrieg zeigten, daß die Zahlung hoher Reparationen durch Deutschland grundsätzlich unmöglich sei, wies R\&A ausdrücklich zurück. Die Abteilung argumentierte, daß das Bruttosozialprodukt 1938110 Milliarden Reichsmark betragen habe, wovon 26 Milliarden für Militärausgaben aufgewendet worden seien, so daß man grundsätzlich davon ausgehen könne, daß Deutschland in der Lage sein werde - „favorable assumptions with regard to boundary changes, social disorganization, etc." vorausgesetzt jährlich Reparationen im Wert von 26 Milliarden Reichsmark zu Preisen von 1938 bzw. 6,5 Milliarden Dollar aufzubringen. Andererseits betonte R\&A aber, daß es vorläufig völlig unmöglich sei, definitive Schätzungen zu geben, da sich erst nach Kriegsende absehen ließe, inwieweit Kriegsfolgen und die von den Siegermächten bestimmten Maßnahmen Deutschlands Fähigkeit zur Leistung von Reparationen beeinträchtigen würden ${ }^{143}$. Da R\&A nicht ausschließen wollte, daß unter den ungünstigsten Um-

${ }^{142}$ Vgl. dazu auch die bei Backer, The Decision to Divide Germany, S.68ff. diskutierten R\&ASchätzungen sowjetischer Kriegsschäden.

${ }^{143}$ Im Mai 1945 legte R\&A dann eine Serie von acht, immer noch als "preliminary" gekennzeichneten Studien vor, in denen die "German Industry from the Point of View of Reparations" untersucht wurde (NA, RG 59, R\&A 3068.1-8); außerdem: NA, RG 59, R\&A 3182.1, „Economic Interests of the European Countries in German Reparations: Immediate Needs of European Reparation Claimants for Relief and Rehabilitation“, 16.7. 1945; und als "Supplements“ zu der oben erwähnten Studie NA, RG 59, R\&A 2350: NA, RG 59, R\&A 2350.1, "Problems of German Reparations: Exportable Surpluses of German Industrial Products", 9.8. 1945, und NA, RG 59, R\&A 2350.2, „Problems of German Reparations: Some Possible Components of Reparation Claims“, 13.8. 1945. Zumindest ein Teil dieser Studien wurde offenbar im Auftrag der amerikanischen Reparationskommission ausgearbeitet, vgl. den Monthly Progress Report der Europe-Africa Division für Mai 1945, in: NA, RG 226, E 42, 
ständen die Entnahme von Reparationen aus der laufenden Produktion für unbestimmte Zeit überhaupt nicht möglich sein würde, konnten alle sich anschließenden Überlegungen nur sehr vorläufigen Charakters sein.

R\&A beschränkte sich denn auch weitgehend darauf, die Fragen und Probleme herauszuarbeiten, die ein künftiges Reparationsabkommen regeln mußte, und darüber hinaus auf der Basis von Zahlen aus der Vorkriegszeit exemplarisch vorzuführen, wie die später notwendigen Berechnungen angegangen werden müßten. Während nicht grundsätzlich ausgeschlossen wurde, daß Reparationen in einzelnen Industrien auch in Form von Demontagen erhoben werden könnten, ging R\&A - ganz im Sinne der von der Abteilung formulierten "US Policy Toward the Economic Disarmament of Germany “144 im allgemeinen davon aus, daß die Siegermächte das industrielle Potential Deutschlands nur insoweit beschränken wollten, als es mit dem von $R \& A$ als vorrangig betrachteten Interesse an einem möglichst bald und in möglichst großem Umfang zu leistenden Beitrag Deutschlands zum Wiederaufbau Europs vereinbar wäre. Anders als die Arbeiten zur Entwaffnung der deutschen Industrie, in denen immer wieder auf Widersprüche hingewiesen und vor einer entsprechend inkonsistenten Politik gewarnt wurde, erwekken die Arbeiten zur Reparationsfrage den Eindruck, als ob man in diesem Bereich kaum mit schwerwiegenden Problemen und Interessenkonflikten rechnete. Was etwa die grundlegenden "policy decisions" zur Reparationsfrage betraf, so hoffte R\&A auf eine Einigung über die „broad general principles governing reparations" und die grundsätzliche Anerkennung des Prinzips, "that reparations shall be handled as a United Nations and not as unilateral operation ${ }^{145}$. Die R\&A-Wirtschaftswissenschaftler scheinen dabei völlig verkannt zu haben, daß gerade darin, daß die am schwersten geschädigte Siegermacht ein sozialistischer Staat war und insofern ein ganz andersgeartetes und sehr viel weitergehendes Interesse an der Reparationsfrage hatte als die kapitalistischen Westmächte, enormer politischer Sprengstoff $\operatorname{lag}^{146}$. Freilich wurde dies auch von den Experten der USSR-Division verkannt, die in einem Arbeitspapier zu den "Capabilities and Intentions of the USSR in the Postwar Period“ ebenfalls die Ansicht vertraten,

b 2. R\&A hatte im übrigen auch schon im Rahmen der Arbeit an den Civil Affairs Guides bzw. im Anschluß daran in einer Reihe von Studien versucht, die wirtschaftliche Situation in Deutschland in der unmittelbaren Nachkriegszeit einzuschätzen, z. B.: NA, RG 59, R\&A 1333.1, "Economic Conditions in Germany at the Cessation of Hostilities", 24.3. 1944; NA, RG 59, R\&A 1788, „The Prospective Development of the German Civilian Labor Force During the Period of German Collapse“, 4.2. 1944; NA, RG 59, R\&A 1788.1, „An Estimate of the Level of Unemployment in Germany During the Period of German Collapse ${ }^{*}$, 25.5. 1944; NA, RG 59, R\&A 3137, "The Size of the German Labor Force 1 June 1945“, 29.5. 1945; NA, RG 59, R\&A 2239.2, „European Civilian Textile Requirements During the First Year of Occupation: Germany“, 18.9. 1944; NA, RG 59, R\&A 2291, "Certain Raw Materials Available in Germany at the Time of Surrender", 24.7. 1944; NA, RG 59, R\&A 2730, (Preliminary) „Expected Food Balance During the First Year of Occupation: Germany, By Regions“, 1.12. 1944.

144 NA, RG 59, R\&A 2469, siehe dazu oben S.160.

145 NA, RG 59, R\&A 2258, „Procurement and Allocation of German Products for the Relief and Reconstruction of Europe", 6.7. 1944.

$146 \mathrm{Vgl}$. dazu allgemein Backer, The Decision to Divide Germany, sowie ders., Priming the German Economy, insbesondere S.60ff.; siehe außerdem Nübel, Die amerikanische Reparationspolitik, und Foschepoth, Konflikte in der Reparationspolitik, in: ders. (Hrsg.), Kalter Krieg und Deutsche Frage, S. 175-197. 
"[that] the collection of reparations [.. . ] is not likely to lead to serious friction with the

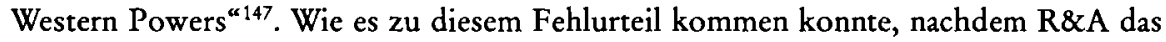
in der Aufteilung Deutschlands in Besatzungszonen angelegte Konfliktpotential doch so realistisch eingeschätzt hatte ${ }^{148}$, ist nur schwer nachvollziehbar.

Gerade die Frage nach eventuellen Konfliktpunkten der jeweils zur Diskussion stehenden deutschlandpolitischen Maßnahmen war schließlich fast schon das „Markenzeichen " der meisten R\&A-Studien zur amerikanischen Deutschlandpolitik. Dabei reflektierte die immer wieder erhobene Forderung nach „establishment and maintenance of unity of policy and interest among the great powers based upon the gradual

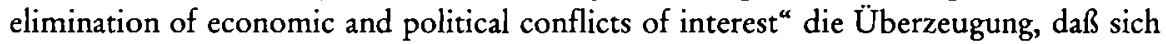
die Nachkriegsentwicklung Deutschlands und Europas zunächst einmal als Funktion des Verhältnisses der Siegermächte untereinander gestalten würde. Explizit oder implizit warnte R\&A deshalb immer wieder davor, daß die Kriegskoalition nach dem gemeinsam errungenen Sieg auseinanderbrechen würde, wenn das sie verbindende Interesse - die militärische Niederringung des nationalsozialistischen Deutschlands - für die Nachkriegszeit nicht neu definiert würde.

Dieser fast allen R\&A-Studien zur amerikanischen Deutschlandpolitik zugrundeliegende Ansatz läßt erkennen, daß R\&A sich nicht darauf beschränken wollte, wissenschaftliche Expertise in "first-class political research on foreign countries“ zu bieten, sondern daß man darüber hinaus bestrebt war, die Ergebnisse der entsprechenden Analysen und Studien in den Kontext einer rational konstruierten Friedensordnung einzuordnen und damit einen Beitrag zur Formulierung der amerikanischen Nachkriegspolitik zu leisten. Die von Hajo Holborn später einmal geprägte Sentenz, „[that] ultimately he wins the war who wins the right peace ${ }^{{ }^{\alpha 14}}$, hätte dabei insofern als Leitmotiv über vielen der R\&A-Studien zur amerikanischen Deutschlandpolitik stehen können, als sie die in den Arbeiten der Abteilung immer wieder erkennbar werdende Überzeugung reflektiert, daß es so etwas wie einen „richtigen“ Frieden gab, und daß dieser nach dem militärischen Sieg erst noch zu „gewinnen“ war.

Doch noch im Laufe des Jahres 1945 sollte sich abzeichnen, daß tatsächlich erst der Krieg, mitnichten aber auch schon der Frieden gewonnen war. Während sich R\&A zugute halten konnte, viele der sich in der unmittelbaren Nachkriegszeit stellenden Probleme antizipiert zu haben, bedeutete gerade die Tatsache, daß sich diese Probleme nun wirklich ergaben, daß die von R\&A ausgesprochenen Empfehlungen und Warnungen wenn nicht ungehört, so doch unbeachtet geblieben waren. Die Entwicklungen der Nachkriegszeit bestätigten so zwar vielfach die Expertise der Abteilung, doch der Versuch, sie für den Prozeß politischer Entscheidungsfindung nutzbar zu machen, schien gescheitert.

Dies dürfte freilich nur bedingt R\&A anzulasten sein. Zwar ließe sich kritisieren, daß die von R\&A angenommenen politischen Rahmenbedingungen einen allzu rationalen politischen Prozeß voraussetzten, in dem kein Raum für nationale Egoismen,

147 NA, RG 59, R\&A 2669, "Capabilities and Intentions of the USSR in the Postwar Period“, (Preliminary version, not officially approved by R\&A for distribution), 5.1. 1945.

${ }^{148}$ R\&A hatte schließlich selbst darauf hingewiesen, daß es nicht unwahrscheinlich sei, daß die Russen versuchen würden, "to integrate their zone into Soviet planned economy in order to facilitate the rehabilitation of Russia's devastated areas." (NA, RG 226, E 1, b 1, f 8, „Proposed Outline for the Organization of Allied Military Government in Germany“).

149 Holborn, Germany and Europe, S. 240 
ideologisch motivierte Ambitionen oder in ihrer Perspektive beschränkten Interessenpolitik war, doch bliebe auch zu fragen, welche Alternative R\&A angesichts des von der "policy of postponement" belassenen Vakuums hatte. Vor allem aber hatte R\&A kaum Einfluß darauf, ob und wie die Arbeiten der Abteilung letztlich genutzt wurden. Zwar kümmerte sich R\&A mit bemerkenswertem Engagement um die „Vermarktung" der eigenen Arbeit ${ }^{150}$, doch glaubte man zuweilen feststellen zu müssen, daß nicht alle Washingtoner Behörden "competence in research and analysis“ zu schätzen wußten ${ }^{151}$. So finden sich dann auch gelegentlich Hinweise darauf, daß sich unter den R\&A-Mitarbeitern "a feeling of frustration“ breitmachte. Man beklagte, daß selbst das State Department, das von R\&A ständig Studien anfordere, nicht willens sei, R\&A-Mitarbeiter ins Vertrauen zu ziehen oder ihnen Gelegenheit zur Teilnahme an Diskussionen zu geben. Wie aus dieser Klage allerdings auch hervorgeht, gab es eine starke Nachfrage nach R\&A-Studien ${ }^{152}$, doch selbst der im State Department für die Verteilung von R\&A-Studien zuständige R\&A-Mitarbeiter konnte über den Gebrauch, der von diesen Arbeiten gemacht wurde, nur spekulieren ${ }^{153}$. Er beschrieb dabei die "Relation of R\&A Papers to State Department Policy" als eine indirekte, denn seiner Ansicht nach war es unrealistisch, wenn R\&A-Mitarbeiter hofften, "that their most suitable studies will be read personally by the appropriate top level officer of the Department". Die den „top level officers" zuarbeitenden Beamten schienen jedoch Gebrauch von R\&A-Studien zu machen, so daß insgesamt festzustellen sei, „that [...] the work done by R\&A not only has much of the effect that it deserves to have upon the formulation of Department policy, but also receives a significant amount of recognition among Department officers generally".

Die R\&A-Arbeiten hier zugeschriebene indirekte Wirkung läßt sich kaum genauer fassen, obwohl eine ganze Reihe von "Indizien“ darauf hindeuten, daß die von R\&A geleistete Arbeit im State Department tatsächlich geschätzt wurde. Immerhin gehörte das State Department während des Krieges nicht nur zu den besten „Kunden“ der R\&A-Branch, sondern vertrat überdies häufig Positionen, die ganz ähnlich auch in R\&A-Studien vertreten wurden ${ }^{154}$. Während es kaum sinnvoll ist anzunehmen, daß das State Department R\&A-Studien anforderte, obwohl sie nicht benutzt oder gar für wertlos gehalten wurden, läßt sich kaum je eine eindeutige Verbindung zwischen den vom State Department und den von R\&A vertretenen Positionen nachweisen. So mag beispielsweise bei den in Vorbereitung der Konferenz von Jalta ausgearbeiteten Denkschriften "The Treatment of Germany" und "Economic Policies Toward Germany" zwar auffallen ${ }^{155}$, daß die darin empfohlene Politik in ihren Grundzügen den von

${ }^{150}$ Dies geht immer wieder aus abteilungsinternen Unterlagen hervor, z. B. NA, RG 226, E 1, b 2, f: State Department 1944, sowie ebenda b 3, „Draft of proposed guide to preparation of political reports", [o.D.], und b 9, f: Political Reports (Preparation of).

${ }^{151}$ Dazu und zum Folgenden NA, RG 226, E 1, b 2, f: Miscellaneous memos to Donovan, "Problems of the R\&A-Branch“, Langer an Donovan, 11.6. 1945.

152 Vgl. dazu oben III., 2. Teil.

${ }^{153}$ NA, RG 226, E 1, b 2, "The Relation of R\&A Papers to State Department Policy ${ }^{\alpha}$, 16.5. 1945.

${ }^{154}$ Dazu auch das Protokoll der Sitzung des Research and Analysis Civil Affairs Committee am 31.7. 1944, wo Franz Neumann mehrfach auf diesen Umstand verweist, in: NA, RG 226, E 37, b 2, f: Civil Affairs-Research and Analysis Civil Affairs Committee.

155 FRUS, Malta and Yalta, S. 178-193. 
R\&A entwickelten Positionen entsprach und daß auch die als Begründung vorgebrachten Argumentationen immer wieder den in R\&A-Studien vorgetragenen Überlegungen ähnelten, doch ist ein direkter Einfluß der von R\&A entwickelten Konzeptionen nur für das Papier zu den „Economic Policies Toward Germany“ nachweisbar. Da dieser direkte Einfluß nur dadurch hergestellt wurde, daß ein R\&A-Mitarbeiter - nämlich der Wirtschaftswissenschaftler Emile Despres - inzwischen zum State Department übergewechselt war, erlaubt dieser Einzelfall kaum allgemeine Rückschlüsse auf die Verwertung von R\&A-Studien. Immerhin läßt sich aber aus einem von Despres Mitte Februar 1945 zirkulierten State Department-Memorandum entnehmen ${ }^{156}$, daß Despres selbst Verfasser der Denkschrift zur Wirtschaftspolitik war, und zudem wird ein Aspekt der "Wirkungsgeschichte“ dieser Denkschrift erhellt. Offenbar war sie an den deutschlandpolitischen Berater Robert Murphy weitergeleitet worden und hatte sich für ihn als so „useful, and in fact essential“ erwiesen, daß er in einem Schreiben an Freeman Matthews, den Direktor des Office of European Affairs im State Department, eigens versuchte zu skizzieren, wie die Denkschrift genutzt worden war, um den von der Finanzabteilung des Kontrollrats vertretenen Vorstellungen - „[which] reflect Treasury thinking “ - die Konzeptionen des State Department entgegenzusetzen ${ }^{157}$.

Sowenig diese Episode allgemeine Aussagen über die politische Relevanz der von R\&A geleisteten Arbeit erlaubt, illustriert sie doch, daß ein zum State Department überwechselnder R\&A-Mitarbeiter seine bisherigen Konzeptionen nicht zu revidieren brauchte, um der von seinem neuen Arbeitgeber befürworteten politischen Linie zu entsprechen. Die immer wieder festzustellende Übereinstimmung zwischen den von R\&A vertretenen Positionen und denen des State Department gibt freilich keinen Aufschluß über den Anteil, den R\&A-Arbeiten an der Meinungsbildung und Entscheidungsfindung im State Department hatten. Wie die oben erwähnten Ausführungen zur "Relation of R\&A Papers to State Department Policy“ jedoch erkennen lassen, wurden die von R\&A ausgearbeiteten Studien im State Department vor allem von den unteren Rängen der Beamtenhierarchie rezipiert. Nur insoweit, als die in R\&A-Studien enthaltenen Informationen, Argumente und Analysen in den auf dieser Ebene ausgearbeiteten Papieren ihren Niederschlag fanden, dürften sie höhergestellte Beamte erreicht haben.

Der Stellenwert der von R\&A geleisteten Arbeit ist in diesem Zusammenhang noch insofern zu relativieren, als R\&A mitnichten die einzige Institution war, die das State Department und andere Washingtoner Behörden mit Berichten und Analysen belieferte; überdies waren die von $\mathrm{R} \& \mathrm{~A}$ vertretenen Positionen in keiner Weise "exklusiv“. Insbesondere die vom Council on Foreign Relations gebildeten Ausschüsse, die sich schon seit Kriegsbeginn erfolgreich um eine institutionell wie personell verankerte $\mathbf{Z u}-$ sammenarbeit mit dem State Department bemühten, scheinen in vielen Fragen zu Ergebnissen gekommen zu sein, die sich von den von R\&A vertretenen Positionen kaum unterschieden ${ }^{158}$. In diesem Zusammenhang dürfte der Beobachtung, daß einzel-

156 NA, RG 59, 862.50/2-1545.

${ }^{157}$ Murphy an Matthews, 24.1. 1945, NA, RG 59, 862.50/1-2445.

158 Vgl. dazu Wala, Winning the Peace, S. $48 \mathrm{ff}$.; siehe auch die spätere Publikation des Council: Price/Schorske, The Problem of Germany, sowie die Veröffentlichung der Brookings Institution: Moulton/Marlio, The Control of Germany and Japan. 
ne R\&A-Mitarbeiter auch Mitglieder der vom Council gebildeten Studiengruppen waren ${ }^{159}$, eine über diese Einzelfälle weit hinausreichende Bedeutung zukommen, denn derartige personelle Verästelungen verweisen auf ein komplexes Netzwerk professioneller Kontakte und persönlicher Bekanntschaften, in deren Rahmen Diskussionen geführt und Ideen ausgetauscht wurden, ohne je dokumentiert zu werden.

Insgesamt sind definitive Aussagen über die politische Relevanz der von R\&A geleisteten Arbeit so kaum möglich. Ex negativo läßt sich zwar mit größerer Bestimmtheit feststellen, daß die ehrgeizigen Hoffnungen der Abteilung, politische Entscheidungen zu beeinflussen, unerfüllt blieben, doch da man angesichts der politischen Entwicklungen des letzten Kriegsjahres und der unmittelbaren Nachkriegszeit auch im State Department Grund gehabt hätte, sich ähnlich frustriert zu fühlen, ist damit nicht unbedingt eine erschöpfende Antwort gegeben. In der Tat hieße es, sich den von R\&A entwickelten Ehrgeiz zu eigen machen, wenn man angesichts des offiziellen Status der Abteilung als einer Art Dienstleistungsbehörde die politische Relevanz der R\&A-Arbeiten daran messen wollte, inwieweit die Nachkriegspolitik der USA den von R\&A entwickelten Konzeptionen folgte. Sehr viel realistischer ist es, nach dem Beitrag zu fragen, den R\&A für die in den letzten beiden Kriegsjahren in Washington ausgearbeiteten politischen Planungen und für die in diesem Zusammenhang geführten Diskussionen leistete. In diesem Prozeß stellten die von R\&A ausgearbeiteten Studien zumindest ihrem Potential nach Denkanstöße, Argumentationshilfen und Konzeptionen für diejenigen bereit, die Politik nicht als Fortsetzung des Krieges mit anderen Mitteln betrachteten, sondern für den Aufbau einer langfristig ausgerichteten, auf Interessenausgleich und Kooperation beruhenden Friedensordnung plädierten. Inwieweit dieses Potential tatsächlich genutzt wurde, ist nicht nachzuweisen, daß es aber geschätzt wurde, ist nicht zu bezweifeln: dafür sprechen nicht nur die in R\&A-Unterlagen gelegentlich notierten positiven Reaktionen einzelner R\&A-,Kunden“, sondern viel deutlicher noch die zuweilen die Grenzen der Arbeitskapazität der Abteilung überschreitende Nachfrage nach R\&A-Studien und schließlich auch die Tatsache, daß R\&A nach Kriegsende nicht wie andere OSS-Abteilungen zur Aufteilung bzw. Auflösung an das War Department überstellt wurde, sondern im State Department den Kern eines neu aufzubauenden Auslandsnachrichtendienstes bilden sollte. Selbst wenn eine genauere Bestimmung der politischen Bedeutung der von R\&A geleisteten Arbeit letztlich kaum möglich ist, dürften diese bislang wenig beachteten Studien als ein Beitrag zu der in Washington geführten deutschlandpolitischen Diskussion zu werten sein, den es für ein Verständnis der längerfristigen Entwicklung der amerikanischen Deutschlandpolitik zu berücksichtigen gilt ${ }^{160}$.

${ }^{159}$ Vgl. dazu die bei Wala, Winning the Peace, im Anhang (S.282ff.) zusammengestellten Listen, die folgende R\&A-Mitarbeiter - entweder vor oder nach, aber auch während deren Tätigkeit für R\&A - als Mitglieder einer oder mehrerer Studiengruppen des Council identifizieren: James P. Baxter III, William L. Langer, Edward M. Earle, Calvin B. Hoover, Crane Brinton, Geroid T. Robinson, Conyers Reed und Whitney H. Shepardson. Siehe außerdem die R\&A-Liste zur "Committee Membership " von Mitarbeitern in NA, RG 226, E 145, B 2, f 25, sowie die in Price/Schorske, Problem of Germany, im Vorwort aufgeführte Liste, die folgende (ehemalige) R\&A-Mitarbeiter als Mitglieder der für dieses Projekt gebildeten Studiengruppe nennt: William L. Langer, Edward S. Mason, Shepard Morgan und DeWitt C. Poole.

160 Siehe dazu unten VIII., 2. Teil. 


\section{Kontinuitäten und Neubeginn: Von der NS-Diktatur zur Militärregierung}

\section{Feldberichte über Besatzer und Besetzte}

Obwohl die alliierte Landung in der Normandie und die Befreiung Frankreichs nicht wie erhofft noch im Laufe des Jahres 1944 zum endgültigen Zusammenbruch Deutschlands führten, konnten amerikanische Truppen im Oktober 1944 doch schon das Gebiet um Aachen besetzen ${ }^{1}$. Die Nachrichtendienststäbe des Militärs wie auch das OSS verloren keine Zeit und nutzten diese erste Gelegenheit, sich nun endlich „vor Ort" über den jahrelang fast hermetisch abgeschlossenen Gegenstand ihrer Arbeit kundig zu machen ${ }^{2}$. Die dabei entstandenen Berichte über Interviews mit Deutschen muten heute zuweilen ganz modern als Dokumente einer "oral history“ an - sie zeichnen Charakter- und Stimmungsbilder, die die zwischen Beharren und Umbruch verunsicherten Mentalitäten und den profanen, um kaum mehr als die simpelsten Grundbedürfnisse kreisenden Alltag breiter Bevölkerungsschichten dokumentieren.

In einem der ersten Berichte wird der 53jährige Elektriker Josef Linden als ein "middle-aged Social Democrat" aus Haaren, einer kleinen Industriestadt bei Aachen, vorgestellt ${ }^{3}$. Das früher „Klein-Moskau“ genannte Haaren schien sich unter Hitler nicht viel verändert zu haben, und auch Linden wollte als ebensowenig verändert erscheinen wie seine Umgebung. Er trat als fast schon fanatischer Sozialdemokrat auf: „He is a Social Democrat; he was a Social Democrat; and he will, he insisted, die a Social Democrat." Linden, der von sich behauptete, daß er lieber gestorben wäre, als „Hitler-made work“ anzunehmen, arbeitete während des Krieges in einer Fabrik, die Meßgeräte für U-Boote herstellte. Sein einziger Sohn fiel im Krieg - „in a foreign country, near Sebastopol, for a cause that was not that of the Lindens". Lindens einzige „Widerstandshandlung “ bestand darin, kein Geld zu sparen, da Ersparnisse seiner Ansicht nach nur dem NS-Regime zugute gekommen wären. „There was nothing else an anti-fascist German worker could do in the face of the Gestapo terror", so erklärte Linden. Für die Zukunft hoffte er auf „a ,small Germany“, a place where ,everybody can speak his mind" and enjoy, freedom of conscience“"; im übrigen wollte Linden am liebsten in einem amerikanisch besetzten, von Deutschland abgetrennten Rheinland le-

${ }^{1} \mathrm{Zu}$ den ersten Monaten der amerikanischen Besatzung vgl. Latour/Vogelsang, Okkupation und Wiederaufbau, S.40ff.; siehe auch den Artikel in der von R\&A-London für die US-Streitkräfte herausgegebenen Publikation European Political Report (EPR): „Military Government in Germany: The First Six Months“, EPR Vol. II, No. 9, 2.3. 1945, in: Hoover Inst., Lerner Collect., b 48, f: European Political Report (OSS, R\&A) 1945.

2 In dieser Phase arbeiteten kleinere, meist nur zwei Mann starke OSS- bzw. R\&A-Teams mit den für Psychological Warfare zuständigen Einheiten des Militärs zusammen, vgl. NA, RG 226, E 115, b 46, f 6; OSS-Zentrale auf dem Kontinent war die im September eingerichtete Außenstelle in Paris.

${ }^{3}$ NA, RG 226, 1143 85, 9.11. 1944, Headquarters T Force, 12 Army Group, APO 655 (Saul K. Padover, Lewis F. Gittler); vgl. die Version über "Josef Minden“ bei Padover, Experiment in Germany, S. $66 \mathrm{ff}$. 
ben, und er versicherte lautstark seine Bereitschaft, „[to] kill anyone who will sabotage or oppose an American occupation".

Den Mitarbeitern der Psychological Warfare Branch schien es „significant of Linden's character, and perhaps also of the German mentality, that he was fully aware that he was helping Hitler's war machine, that he passionately hated the whole Hitler system, yet - by his own admission - he never sabotaged or slowed up his work “. Ähnlich bezeichnend erschien ihnen, daß Linden die "Prussian Junkers" lediglich zu Arbeitseinsätzen verurteilt sehen wollte - „so that they would have no time to think up another war" ${ }^{\text {" }}$, während er die Nazi, lumpen“ "gehängt wissen wollte, denn, so argumentierte er: „They hang their own brothers." Auf die Frage, welche „Brüder“ sie gehängt hätten, kam die erregte Antwort: „They hanged the best - the best - in Germany. They hanged the Generals - the best in Germany."

Diese "Charakterstudie" eines Vertreters der gesellschaftlichen Gruppe, aus der die Militärregierung Personal für die entnazifizierten Behörden rekrutieren sollte, mochte zunächst eher desillusionierend sein. Ähnliche Gespräche in den nächsten Wochen und Monaten erlaubten es den Mitarbeitern der Psychological Warfare Division aber bald, ein etwas differenzierteres Bild dieses politischen Spektrums zu zeichnen: „We spoke with several Socialists and found them to be nationalist although not militarist, Germanic but not chauvinistic." Die Sozialdemokraten in Deutschland repräsentierten immer noch den gemäßigten, westlich orientierten Teil der Arbeiterschaft, während die Kommunisten weiterhin die radikaleren, pro-russisch eingestellten Arbeiter vertraten ${ }^{4}$.

Die Mitarbeiter der Psychological Warfare Branch interessierten sich selbstredend auch für das Verhalten derjenigen, die sich noch bis vor kurzem zum Nationalsozialismus bekannt hatten. Exemplarisch wurde ein ehemaliger Obersteuerinspektor aus Aachen vorgeführt ${ }^{5}$, der für sich in Anspruch nahm, daß er der NSDAP gewissermaßen von Amts wegen hätte beitreten müssen. Gegenüber seinen amerikanischen Gesprächspartnern äußerte er sich nun kritisch über die Politik der Nationalsozialisten und den Krieg, Hitlers "Großraumpolitik“ vor dem Krieg wollte er allerdings nicht verurteilen. In der Psychological Warfare Branch glaubte man, daß in diesem Bericht "the mind of a Nazi bureaucrat" beispielhaft vorgeführt werde, und man sah das Verhalten des Aachener Obersteuerinspektors als "model-type [...] which the occupying authorities may expect from other bureaucrats and last-minute converts to ,anti-Nazism "“6 6 .

${ }^{4}$ NA, RG 226, 1195 32, SHAEF, Psychological Warfare Division, Intelligence Section: „A Socialist's Views on Partition and the Future of Germany", (Report from P \& PW, 9th U.S.Army, wie der obige Bericht von Padover/Gittler), 27. 2. 1945; NA, RG 226, E 50, b 1, SCI Det., G-2 CIB, HQ 12th Army Group, 30.3. 1945, Edgar M. Hoover und Hans Meyerhoff an Harold Deutsch, Chief of R\&A, Paris, und Chandler Morse, Chief of R\&A ETO, Memorandum „Position of Anti-Nazi Groups in Krefeld“.

5 NA, RG 226, 1293 16, HQ T Force, 12 Army Group, „A Nazi states his reasons for rejecting Nazism now“; To: Psychol. Warfare Officer; From: Adv. Det., PWB, 12 AG, 3. 12. 1944; es handelt sich offenbar um das bei Padover, Experiment, S. $151 \mathrm{ff}$. wiedergegebene Interview mit "Leo Kalff“.

6 Ähnliche Erfahrungen wurden von den Mitarbeitern der Psychological Warfare Branch bald auch als "Lehrstücke" benutzt: um die deutsche Bevölkerung über "the almost incredible selfishness and incorrigible self-satisfaction and political blindness of scions of the German aristocracy, generals, and industrial magnates “ aufzuklären, stellte man Berichte über erste Zusammentreffen amerikanischer Einheiten mit Vertretern dieser Kreise zusammen, vgl. NA, 
Derartige Einzelinterviews wurden bald durch Berichte ergänzt, die das wieder aufkeimende öffentliche Leben und die ersten tastenden Versuche politischer Betätigung dokumentieren. So übersandte R\&A-Mitarbeiter Harold Deutsch dem Büro in Washington Anfang März einen Bericht, der während einer längeren Kampfpause entstanden war, die Mitarbeiter der Psychological Warfare Branch genutzt hatten, um die Verhältnisse in Herzogenrath zu studieren ${ }^{7}$. Seit Frühjahr 1945 berichteten R\&A-Mitarbeiter auch in zunehmendem Umfang über ihre Inspektionsreisen, wobei sich das Blickfeld nun ständig erweiterte: neben Aufzeichnungen über einzelne Gespräche traten erste Eindrücke über die materiellen wie „psychologischen“ Kriegsschäden sowie Beobachtungen über den Aufbau der Militärverwaltung ${ }^{8}$.

Immer wieder kommt in diesen Berichten zum Ausdruck, daß die Zerstörung weitaus umfangreicher war, als man angenommen hatte. Besonders die Zentren der größeren Städte werden als völlig verwüstet beschrieben, die städtische Infrastruktur sei infolgedessen größtenteils lahmgelegt, während die häufig am Stadtrand gelegenen Industrieviertel meist weniger gelitten hätten und teilweise leicht wieder in Stand gesetzt werden könnten. Schon angesichts dieser physischen Zerstörungen wurden immer wieder Zweifel geäußert, ob sich die Planungen für den Aufbau der alliierten Militärverwaltung in Deutschland als realistisch bzw. realisierbar erweisen würden. Kaum weniger fragwürdig erschienen bald auch die Erwartungen, die man gerade in R\&A an die "demokratischen“ Kräfte in Deutschland gehabt hatte, denn es wurde zunehmend deutlich, daß sechs Jahre NS-Diktatur und sechs Jahre Krieg nicht viel von jenen politischen Kräften übriggelassen hatten, von denen R\&A ein entschiedenes Eintreten für eine tiefgreifende Demokratisierung Deutschlands erhofft hatte.

Was sich R\&A-Mitarbeiter Just Lunning einprägte, als er im März 1945 knapp zwei Wochen durch die wichtigsten der von den Amerikanern bislang eingenommenen Städ-

RG 226, 12 65 65, SHAEF, Psychological Warfare Division, 21.4. 1945, „Guidance for Output in German for the Week 23-30 April 1945".

7 NA, RG 226, 1194 96, HQ \& HQ Detachment, OSS, ETO, (von Harold Deutsch an William Langer, zur Weitergabe an Carl Schorske und Franz Neumann), 11.3. 1945. Einen ähnlichen, allerdings anscheinend sehr brisanten, ebenfalls vor Ort ausgearbeiteten Bericht muß es über Aachen gegeben haben, vgl. die Unterlagen in NA, RG 226, E 1, b 2, f: Secret memos to Donovan (Februar 1945), der Bericht ist allerdings nicht vorhanden. Es dürfte sich jedoch um den bei Padover, Experiment, S.218ff. wiedergegebenen Bericht handeln. Auch später wurden noch ähnliche Studien ausgearbeitet, siehe die unten erwähnte Studie über Darmstadt.

${ }^{8}$ Zum Folgenden NA, RG 226, E 75, b 1, f: Correspondence France (Incoming) 1945: HQ \& HQ Detachment, OSS, ETO, Just Lunning an Chandler Morse, "Report on Trip Taken in the 12th AG Area from 22 March to 3 April“, 4.4. 1945. Vgl. in diesem Zusammenhang auch den Bericht Lerners in: Borsdorf/Niethammer (Hrsg.), Zwischen Befreiung und Besatzung, S. 27-40; siehe außerdem: NA, RG 226, E 50, b 1: Bericht von Moses Abramovitz über "Trip Through Western Germany“, 14.5. 1945; in deutscher Übertragung auszugsweise wiedergegeben in Borsdorf/Niethammer (Hrsg.), Zwischen Befreiung und Besatzung, S. 47-57; Abramovitz war nach Borsdorf/Niethammer zu diesem Zeitpunkt bereits Wirtschaftsberater des US-Delegierten bei der interalliierten Reparationskommission in Moskau, Isidor Lubin, und unternahm die Reise in dessen Auftrag. Vgl. in diesem Zusammenhang außerdem Walter Dorns Bemerkungen in ders., Inspektionsreisen in der US-Zone, S.24ff. Im übrigen: European Political Report, Vol. II, No. 4, 26.1. 1945: „Occupied Germany: The Eschweiler Bergwerksverein“, und Vol. II, No. 9, 2. 3. 1945: „Military Government in Germany: The First Six Months“, in: Hoover Inst., Lerner Collect., b 48, f: European Political Report (OSS, R\&A) 1945. 
te reiste, entspricht so auch den ersten Eindrücken vieler seiner Kollegen: „The destruction is far beyond what we imagined. In addition to the destruction of buildings, the community itself seems to have ceased to exist. In this situation it becomes very difficult to carry out many of the MG plans in the preparation of which we participated. [...] It may take some time before the average German will participate actively in political life. At the present time, he strikes you as, in Padover's phrase, abgestumpft'. He is primarily concerned with his own personal problems with no feeling or energy for the community itself."

Lunning hatte bei dieser Reise allerdings auch Gelegenheit, mit einem Deutschen zusammentreffen, der - alles andere als „abgestumpft“ - bereits umfassende Vorstellungen darüber entwickelt hatte, wie es mit Deutschland in der Nachkriegszeit weitergehen sollte. Am 28. März hatte Lunning nämlich Konrad Adenauer auf dessen Einladung zu einem etwa einstündigen Gespräch aufgesucht: „Adenaur [sic!] began the interview with a long lecture of the two Germanies; the Germany that is essentially based on Roman culture and the Germany of Prussia and how the latter has imposed its will on the former [...] Adenaur then outlined what he considers the ideal solution which involved organizing a Bundesstaat consisting of Austria, the remnants of Prussia, West Germany (Westphalia and the Rhineland) and South Germany. By making Prussia only one of four states, it would be possible to neutralize the essentially nonGerman Prussian influence."

Adenauer konnte sich allerdings das Rheinland auch als eigenständigen Staat vorstellen, solange es nicht der Kontrolle Frankreichs unterstellt würde, denn er glaubte, daß Frankreich das Rheinland ruinieren würde. Nach seinen Erwartungen für ein Wiedererwachen des politischen Lebens in Deutschland befragt, äußerte Adenauer die Ansicht, daß es zunächst einmal notwendig sei, „to re-educate all the Germans who have been poisoned by the Nazis“; erst zu einem späteren Zeitpunkt könnten die alten politischen Parteien wieder aufgebaut werden, wobei die frühere Aufsplitterung allerdings vermieden werden sollte. Vorläufig war es nach Adenauers Ansicht durchaus angebracht, daß die Militärregierung keine politische Betätigung zuließ.

Ohne die von Adenauer entwickelten Vorstellungen zu kommentieren, erwähnte Lunning noch kurz dessen Beratertätigkeit für die amerikanische MG-Einheit in Köln, um dann hervorzuheben, daß sich diese Einheit positiv von anderen unterscheide. Tatsächlich bescheinigten mehrere R\&A-Berichte der Militärverwaltung in Köln ein geradezu vorbildliches Vorgehen ${ }^{9}$. Als besonders bemerkenswert bewertete man es in R\&A, daß sich das für Köln eingeteilte MG-Team schon vor der Besetzung der

\footnotetext{
9 Vgl. dazu und zum Folgenden neben dem in Anmerkung 8 zitierten Bericht Lunnings NA, RG 226, E 50, b 1, Schreiben von Hans Meyerhoff an Harold Deutsch, Chief R\&A/Paris, und Chandler Morse, Chief R\&A/ETO, zur Weitergabe an Felix Gilbert, über „political appointments by $M G^{\circ}$ vom 7.3. 1945 (Secret, internal use only); und ebenda, Schreiben von E.M.Hoover und Hans Meyerhoff an Harold Deutsch, Chief R\&A/Paris, und Chandler Morse, Chief R\&A/ETO, 2.4. 1945 (SECRET - Not to be shown outside OSS), "Notes on the Political Role of Military Government"; sowie dies. an dies., "Position of Anti-Nazi Groups in Krefeld“, 30.3. 1945 (im Anhang Notizen zur Situation in Düsseldorf-Oberkassel und Köln). Im letztgenannten Bericht weisen Hoover und Meyerhoff darauf hin, daß sie davon gehört hätten, what a favorable account of Lt. Col. Patterson's operation in Cologne appears in the 26 March issue of TIME“.
} 
Stadt Gedanken über seine künftigen Aufgaben gemacht und den Entschluß gefaßt hatte, nicht nur eine konsequent entnazifizierte, sondern auch eine repräsentative, $d . h$. alle wichtigen gesellschaftlichen Gruppen erfassende Verwaltung aufzubauen. An anderen MG-Teams wurde dagegen kritisiert, „[that] one of the first actions of all the MG officers seems to be to send for the priest or perhaps the Bishop to get his advice about a number of matters" ${ }^{10}$. Das Ergebnis derartiger Praktiken sei, daß letztlich die eine Herrschaftselite nur durch eine andere ausgetauscht würde, was dem von R\&A vertretenen Demokratieverständnis kaum genügen konnte.

Freilich räumte man in $R \& A$ ein, daß die Militärregierungen meist unter denkbar ungünstigen Bedingungen operieren mußten. Solange die Kämpfe noch andauerten, hatten militärische Gesichtspunkte absolute Priorität. Die politischen Direktiven, an deren Richtlinien sich die MG-Einheiten im übrigen orientieren sollten, waren nach Ansicht von R\&A oft widersprüchlich und zuweilen gar schlichtweg unrealistisch. Ein grundsätzliches Problem sah R\&A zudem darin, daß die personelle Ausstattung vieler MG-Einheiten in quantitativer wie qualitativer Hinsicht sehr zu wünschen übrig lasse ${ }^{11}$. Auch in dieser Hinsicht stellte Köln eine Ausnahme dar, da das dortige Team - ein für die Verwaltung einer ganzen Provinz vorgesehenes „E“-Team - 42 Offiziere umfaßte ${ }^{12}$, während in anderen Städten wie beispielsweise Krefeld vergleichbare Aufgaben von einem Team mit nur drei Offizieren bewältigt werden müßten. Unter diesen Umständen könne dem Aufbau einer Verwaltung bzw. der Auswahl neuen Personals kaum die notwendige Sorgfalt zukommen, und nicht selten würden für dringend notwendige Funktionen so „by default $[\ldots]$ the remaining old-time civil servants" nominiert. Es bliebe meist $\mathrm{CIC}$, den für "counter-intelligence" zuständigen $\mathrm{Ab}$ teilungen von G-2, überlassen zu prüfen, ob die von der Militärregierung für ein Amt vorgeschlagenen Kandidaten politisch akzeptabel seien. Tatsächlich sei CIC aber in erster Linie dafür verantwortlich festzustellen, ob die jeweils Nominierten militärische Sicherheitsinteressen gefährden könnten. Nach Ansicht von R\&A nahmen die CICMitarbeiter ihre Aufgabe sehr ernst; manche Vertreter der Militärregierung zeigten sich fast schon verärgert, da sie zuweilen das Gefühl hatten, "that CIC is making things harder for MG by blacklisting some of its best officials". Im allgemeinen gingen die überlasteten MG-Offiziere dann davon aus, "that anyone not rejected by $\mathrm{CIC}$ as a menace to military security is ipso facto politically acceptable for appointment".

Nicht zu unterschätzen seien schließlich die persönlichen politischen Überzeugungen der MG-Offiziere: „The political role of MG cannot be separated from the social background and the corresponding social and political attitudes of its officers." Diese Offiziere seien vor allem aufgrund ihrer fachlichen Kompetenz ausgewählt worden - „qualified lawyers for the legal branches, bankers for finance, policemen for Public Safety, businessmen for Economics and supply"; in ihrer Mehrheit gehörten sie dem konservativen gehobenen Mittelstand an, und ihren politischen Grundüberzeugungen entsprechend sähen viele von ihnen "leftist forces“ als "dangerous

\footnotetext{
${ }^{10}$ So Lunning in seinem Bericht, s.o. Anmerkung 8.

11 Vgl. dazu auch die ebenfalls kritischen Bemerkungen bei Zink, The United States in Germany, S.7ff.

$12 \mathrm{Zu}$ diesen organisatorischen Einzelheiten ebenda, S. $36 \mathrm{ff}$.
} 
and revolutionary elements which they reject in any other society as much as in their own“. Grundsätzlich kritisierte R\&A in diesem Zusammenhang, daß sowohl bei der Planung der Besatzungspolitik wie bei der Ausbildung des MG-Personals technische und administrative Qualifikationen im Vordergrund gestanden hätten; völlig vernachlässigt worden seien dagegen "the ultimate political implications and objectives of MG's policy".

Nach Ansicht der aus Deutschland berichtenden R\&A-Mitarbeiter wurde die politische Rolle der MG-Teams aber nicht nur durch diese immanenten Faktoren geprägt, sondern auch schon durch die in ihren ersten Ansätzen erkennbar werdenden politischen Kräfte in der deutschen Gesellschaft. Die Interaktion zwischen Besatzern und Besetzten gestaltete sich allerdings anders, als man es sich vorgestellt hatte - und zwar nicht nur anders, als man in R\&A gehofft hatte, sondern auch anders, als diejenigen erwartet haben dürften, die in Deutschland eine liberale, traditionellen amerikanischen Vorstellungen entsprechende Demokratie aufbauen wollten. Denn zum einen waren manche der auf deutscher Seite erkennbar werdenden Vorstellungen über einen demokratischen Wiederaufbau Deutschlands nach amerikanischen Maßstäben kaum als demokratisch zu verstehen ${ }^{13}$, zum anderen mußten diejenigen, die - wie viele R\&A-Mitarbeiter - große Hoffnungen und Erwartungen im Hinblick auf die politische Rolle des Widerstands bzw. seiner demokratischen Kräfte gehegt hatten, bald erkennen, daß sie manches falsch eingeschätzt hatten ${ }^{14}$.

"There is a great poverty in men as well as ideas among the anti-Nazi forces", so konstatierten zwei R\&A-Mitarbeiter Ende März 1945 in einem Bericht über „AntiNazi Groups in Krefeld“. Politisch orientierten sich diese Gruppen wieder an den großen Parteien der Weimarer Republik, also dem Zentrum, der SPD und der $\mathrm{KPD}$, doch müsse ein Großteil der ehemaligen Anhängerschaft dieser Parteien als „more or less infected with Nazism“ gelten. Zudem sei es den Nazis gelungen "perhaps better than we ever imagined“, wie angemerkt wurde - den Widerstand vollständig zu "atomisieren“. Furcht, gegenseitiges Mißtrauen und Isolation hätten jegliches politisches Denken erstickt; der Luftkrieg hätte schließlich ein übriges getan und das Leben der meisten auf die tägliche Sorge um das eigene Überleben reduziert.

Für die Nachkriegszeit falle überdies besonders ins Gewicht, daß diese Gruppen durch zahlreiche „Säuberungsaktionen " der Nationalsozialisten ihrer politischen Führungsschicht beraubt worden seien. Dies gelte für die Sozialisten und Kommunisten in weitaus höherem Maße als für das Zentrum, denn: „Of the latter a considerable number of leading personalities managed to strike a modus vivendi with the regime."

13 Vgl. dazu auch Friedrich, Military Government and Democratization, in: ders. u. a., American Experiences in Military Government, S. 3-20.

${ }_{14}$ Dazu und zum Folgenden vor allem NA, RG 226, E 50, b 1: SCI Det., G-2 CIB, HQ 12th Army Group, Memorandum "Position of Anti-Nazi Groups in Krefeld“; To: Harold Deutsch, Chief of R\&A, Paris, Chandler Morse, Chief of R\&A, ETO; From: Edgar M. Hoover, Hans Meyerhoff, 30.3. 1945; vgl. dazu auch Walter Dorns Notizen aus Krefeld in: ders., Inspektionsreisen, S. 30-34. Außerdem: „Views of a Left-Wing German Catholic“, European Political Report, Vol. II, No. 15, 13.4. 1945, in: RG 243, E 36, b 96 (155); bei dem in diesem Bericht anonym bleibenden Katholiken dürfte es sich um "Willi Elfes“ (Name laut Padover) handeln, vgl. Padover, Experiment, S. $318 \mathrm{ff}$. 
Die Parteien der Linken schienen dagegen „simply decapitated“ und seien nun nicht einmal in der Lage, der Militärregierung wenigstens Kandidaten für höhere Ämter, geschweige denn für alle der neu zu besetzenden Positionen zu benennen. So hätten der Militärregierung in Krefeld nur ehemalige Zentrumsmitglieder zur Verfügung gestanden, und während die Linke sich entrüste, "[that it is] MG's policy to keep on former Nazis and to replace, as they put it, the ,brown' dictatorship by a new ,black' clique", hätte man in diesen Kreisen selbst zugeben müssen, daß man nicht über entsprechende Kandidaten verfüge. Auch den R\&A-Mitarbeitern, die ausdrücklich autorisiert worden waren, nach geeigneten Kandidaten zu suchen, die die in der Stadtverwaltung noch beibehaltenen kompromittierten Amtsinhaber ersetzen könnten, gelang es nicht, entsprechende Personen ausfindig zu machen.

Freilich versprach die ehemalige Zentrumspartei im Krefeld der Nachkriegszeit auch die stärkste Partei zu werden: Schon im März 1945 erforschten die R\&A-Mitarbeiter, wie eine Wahl zu diesem Zeitpunkt ausfallen würde, und die Ergebnisse ihrer - allerdings notwendigerweise nur unsystematischen - Umfrage wiesen darauf hin, daß das Zentrum zweifellos den höchsten Stimmenanteil erhalten würde. Zu ganz ähnlichen Ergebnissen kam man auch in Köln: Nach Umfragen in einem Arbeiterviertel wollten dort $60 \%$ für das Zentrum stimmen, die Sozialdemokraten kamen auf $35 \%$, die Kommunisten auf $4 \%$; der Vergleich mit einem bürgerlichen Wohnviertel ergab eher geringe Abweichungen, nämlich $10 \%$ mehr für das Zentrum und $7 \%$ weniger für die SPD. Bei einer Bürgermeisterwahl wollte eine überwältigende Mehrheit in beiden Vierteln für Adenauer stimmen.

Auch wenn die von der Militärregierung in Krefeld eingesetzte Verwaltung vor diesem Hintergrund als weniger unrepräsentativ erscheinen mochte, konstatierte man nicht nur in R\&A mit Unbehagen, daß manche der neuen Stelleninhaber ein Demokratieverständnis zeigten, das nach amerikanischen Maßstäben kaum akzeptabel war. Mit einigem Befremden mußte man allerdings feststellen, daß sich selbst die politischen Gegner der betreffenden Personen daran nicht unbedingt zu stören schienen. Als Beispiel wurde in dem Bericht über Krefeld der dort von der Militärregierung eingesetzte Bürgermeister Stepkes genannt ${ }^{15}$. Obwohl er sich geweigert habe, in die NSDAP einzutreten und deshalb 1933 als Oberbürgermeister von Kleve abgesetzt worden sei, entsprach Stepkes nach Ansicht der R\&A-Mitarbeiter in hohem Maße dem „old picture of a professional, conservative Centrist who has absorbed a certain unmistakable blend of Nazi ideology“. Während Stepkes den Nationalsozialisten vorwarf, den Rechtsboden des Staates verletzt und ein "government of men, not of laws“ aufgebaut zu haben, war ihnen nach Stepkes’ Meinung andererseits zugute zu halten, daß sie Vollbeschäftigung erreicht, den "Arbeitsfrieden“ gesichert und ein effizientes Wohlfahrtssystem organisiert hätten. Vor allem die, die "meckerten“, seien verfolgt worden; den von R\&A-Mitarbeitern vorgebrachten Einwand, „that our side considers public ,griping“ (Meckern) the essence of democracy“, wollte Stepkes nicht gelten lassen, denn „Mekkern“ war seiner Ansicht nach „certainly not a ,necessity of life“ (lebensnotwendig)“; zudem, so bemerkte er, sei nicht jedes Land „politically mature enough for the same type of democracy“.

15 Einen ähnlichen Fall aus Stolberg berichtet Hans Meyerhoff, Schreiben vom 7.3. 1945 („political appointments by $\mathrm{MG}^{\star}$ ), in NA, RG 226, E $50 \mathrm{~b} 1$. 
Trotz dieser Ansichten sei Stepkes allgemein als aufrichtiger Nazigegner respektiert, und auch die R\&A-Mitarbeiter wollten ihm nicht absprechen, daß er sich zumindest in begrenztem Umfang für die Wiedereinführung demokratischer Strukturen einsetzte, obwohl man in R\&A nicht ohne Mißtrauen konstatierte, daß Stepkes bereits fürchtete, daß sich die Gewerkschaften zu politischen Kampforganisationen entwickeln könnten. Insgesamt notierte man jedoch, "that his generally, fascist' social attitudes are thought by himself, his group, and even by most of his political opponents, to be compatible with his expressed desire to revive certain ,democratic' forms". Freilich zeigte sich Stepkes nach Darstellung von R\&A nur bedingt bereit, politische Gegner in seine Verwaltung aufzunehmen. Zwar hatte er einen Sozialdemokraten für das Arbeitsamt nominiert, doch nach Einschätzung von R\&A hatten Kommunisten, selbst wenn sie durchaus als qualifiziert galten, kaum eine Chance, von ihm als Mitarbeiter akzeptiert zu werden.

So gewannen die aus Deutschland berichtenden R\&A-Mitarbeiter den Eindruck, „[that the] accidental presence or absence of forceful personalities may frequently shape the political complexion at any given locality“. Diese an sich neutrale Feststellung las sich vor dem Hintergrund der von R\&A vermittelten Information über die brutale Dezimierung der politischen Führungsschicht der Linken durch die Nazis eher dahingehend, daß die konservativen und bürgerlichen Kräfte in dieser Umbruchsphase deutliche Vorteile hatten. Aus diesen Gruppen schienen weitaus mehr "forceful personalities" das NS-Regime unbeschadet überlebt zu haben, und selbst dann, wenn sie als Nazi-Sympathisanten gelten konnten, glaubte die Militärregierung zuweilen, nicht auf ihre Expertise in Verwaltung und Industrie verzichten zu können. Die dagegen als "decapitated" erscheinende Linke hatte dem oft wenig entgegenzusetzen; sie schien verunsichert und eher abwartend - „waiting to see how much and what kind of political activity would be possible under MG; [...] waiting to see what kind of Socialist line would develop on higher levels" ${ }^{\text {"16 }}$.

Die anfänglichen politischen Aktivitäten der Linken spiegelten diese Situation insofern wider, als an vielen Orten zunächst ohne eine klar bestimmte "Socialist line" versucht wurde, alle „antifaschistischen" Kräfte der Gesellschaft zu mobilisieren und sie in einer Art Selbsthilfegruppen zu organisieren, um die sich vor Ort stellenden Probleme anzugehen ${ }^{17}$. Diese Organisationsform brachte diese Gruppen allerdings auch sogleich mit den von den Militärregierungen auferlegten Restriktionen - Ausgangssperren, Verbot politischer Versammlungen etc. - in Konflikt und ließ sie gegenüber dem konservativen Lager wiederum ins Hintertreffen geraten.

Von den aus Deutschland berichtenden R\&A-Mitarbeitern wurde dies zunächst eher konstatiert denn kritisiert. Ähnlich wie manche der von ihnen befragten Vertreter der Linken schienen sie bereit zu akzeptieren, daß militärische Erwägungen anfänglich absolute Priorität hatten und daß der Handlungsspielraum der "Antifas" dadurch zwangsläufig eingeschränkt wurde. Dennoch ist die Berichterstattung über diese Gruppen geeignet, daran zu erinnern, daß sie weit und breit die einzigen waren, die den in früheren R\&A-Studien formulierten Hoffnungen und Erwartungen an die von der

16 Vgl. den Artikel des R\&A-Mitarbeiters Leonard Krieger, The Inter-Regnum in Germany: March - August 1945, in: PSQ LXIV, 1949, S.507-532, insbesondere S. $508 \mathrm{ff}$. , der viele der von R\&A vertretenen Positionen reflektiert.

17 Vgl. dazu Niethammer/Borsdorf/Brandt (Hrsg.), Arbeiterinitiative 1945. 
Herrschaft der Nationalsozialisten befreiten demokratischen Kräfte in Deutschland nahekamen ${ }^{18}$. Illustrativer als die einzelnen Feldberichte ist in diesem Zusammenhang eine zusammenfassende, wohl von R\&A/Washington herausgegebene Studie über „Action Groups in Germany“ vom 25. Juni $1945^{19}$.

In diesem Bericht werden diese Gruppen nach ihren unterschiedlichen Zielsetzungen in konservative und antifaschistische bzw. linke Gruppierungen eingeteilt. Die vor allem in Industrieregionen gebildeten antifaschistischen Gruppen hätten zunächst als lokale Selbsthilfeorganisationen fungiert und politische Fragen zurückgestellt. Grundsätzlich strebten sie jedoch eine radikale Entnazifizierung an; auf längere Sicht hofften sie, "to achieve a coalition of genuine anti-fascists regardless of former political affiliations and to prepare for a future democratic German government". Durch ihre politische Betätigung hätten diese Gruppen aber zum Teil gegen Vorschriften der Militärregierung verstoßen, in Einzelfällen hätten sie ihre Anerkennung als örtliche provisorische Regierung gefordert, und so sei - „[in] conformity with Allied occupation policy" - offiziell die Auflösung dieser Gruppen angeordnet worden.

Die Konservativen hätten auf subtilere Weise versucht, politischen Einfluß geltend zu machen. Sie hätten die nationalsozialistische Herrschaft mehr oder minder bereitwillig mitgetragen und insofern weniger unter ihr gelitten, und: „Since the fall of the Nazis they have retained or received the most important positions in German society. They do not share the Left's anti-fascist attitudes, oppose any increased power for labor in business and public administration, and hope by exploiting friction between the Western Powers and the USSR to preserve their present dominant position and retain what is potentially valuable in the shambles left by the Hitler regime."

Ohne daß die Militärregierung hier offen kritisiert wurde, kam diese Darstellung doch einer Kritik gleich, denn immerhin erschien die Militärregierung als fast schon übertölpelter Handlanger einer opportunistischen Herrschaftselite, die nichts anderes als ihren eigenen Vorteil im Sinn hatte. Diese eher indirekte Kritik war freilich milde eingedenk der Eindringlichkeit, mit der R\&A bei der Ausarbeitung der Civil Affairs Guides immer wieder versucht hatte zu verdeutlichen, daß diese im buchstäblichen Sinne „konservativen“ Kräfte nicht die Träger einer wirklichen Demokratisierung Deutschlands sein könnten ${ }^{20}$.

Die von R\&A hier gezeigte Zurückhaltung mag sich zum Teil wieder aus der Einsicht erklären, daß es sich die Abteilung nicht erlauben könnte, als „pressure group“ aufzutreten $^{21}$; daneben dürfte diese Zurückhaltung aber auch den Tenor der Meldungen aus Deutschland widerspiegeln, in denen immer wieder anklang, daß man über eine noch

${ }^{18}$ Vgl. dazu neben dem oben (Anmerkung 14) genannten Bericht über Krefeld den von Borsdorf/ Niethammer (Hrsg.), Zwischen Befreiung und Besatzung, S. 83 ff. abgedruckten Bericht Meyerhoffs sowie die beiden sich daran anschließenden Field Intelligence Studies; siehe außerdem den ganz aus der Perspektive des Widerstands geschriebenen "Comprehensive Report of Trip through Germany in NA, RG 226, E 108, b 8, f 60, auch in E 125, b 11, 18.6. 1945, sowie "Anti-Fascist United Front Movements in Germany“, vom 27.6. 1945, in: NA, RG 226, E 74, b 2, f: J.I.C.

19 NA, RG 59, R\&A 3145 S, Current Intelligence Study Number 25, „Action Groups in Germany“, 15.6. 1945.

20 Siehe oben V., 1. Teil.

${ }^{21}$ Siehe die oben V., 2. Teil, diskutierten R\&A-Richtlinien für die Ausarbeitung politischer Berichte. 
weitgehend offene und kaum überschaubare Situation berichtete. Gerade die ersten Meldungen über die in einigen Städten angetroffenen „Antifas" fielen noch in die Anfangs- und Aufbauphase der Militärregierungen und damit in eine Situation, die insgesamt noch sehr im Fluß war. Darauf wiesen manche Berichte ausdrücklich hin ${ }^{22}$; so hatte es etwa Anfang April in einem R\&A-Bericht geheißen: „[The] crucial political issues in Germany will take shape at a considerable later period so that the earliest operations by MG though important will not always be decisive for the future role and influence of the various anti-Nazi political forces in Germany. "Einerseits, so wurde ausgeführt, müßten sich die politischen Kräfte in Deutschland noch formieren, andererseits vollziehe sich auch der Aufbau der Militärregierung als Prozeß. Verschiedentlich hatten R\&AMitarbeiter die Erfahrung gemacht, daß MG-Einheiten anfänglich belastete Personen als „Notlösung“ einsetzten bzw. beibehielten, daß aber, sobald die wichtigsten Grundprobleme gelöst waren, diese Personalentscheidungen revidiert wurden.

Erst die Kapitulation Deutschlands und die Übernahme der Regierungsgewalt durch die Alliierten Anfang Mai bzw. Juni 1945 erlaubte den Aufbau dauerhafterer Strukturen und damit ein gewisses Maß an Konsolidierung. Für R\&A verbesserten sich die Arbeitsbedingungen nun insofern, als kurz nach Kriegsende, nämlich noch im Mai 1945, ein OSS-Büro in Deutschland eingerichtet wurde. Die Entsendung und Stationierung einer „OSS Mission to Germany" war schon seit Herbst 1944 geplant. Das OSS hatte sich offenbar nützlich genug gemacht, um für dieses Vorhaben einen einflußreichen Fürsprecher zu finden: Stabschef Generalleutnant Walter Bedell Smith hatte in einem Schreiben an die JCS ausgeführt ${ }^{23}$, daß das OSS auf dem europäischen Kriegsschauplatz ein umfassendes Nachrichtendienstnetz mit qualifizierten Mitarbeitern aufgebaut habe, die während der Besatzung wertvolle Dienste leisten könnten. Smith empfahl deshalb, "that the Office of Strategic Services be authorized to establish and operate a special mission for Germany [...] to assist and eventually to serve under the direction and control of the U.S.Group, Control Council, in connection with German disarmament, military government and other matters".

Die JCS sowie War und State Department stimmten Anfang 1945 der Einrichtung dieser „OSS Mission to Germany" zu$^{24}$, und Ende Mai konnte sich das OSS schließlich in Biebrich bei Wiesbaden etablieren. Die unter der Leitung von Harold Deutsch stehende R\&A-Branch dieser Außenstelle entwickelte sich bald zu einer der wichtigsten Abteilungen von OSS/Germany. Anhand der von der Abteilung geführten „Progress Reports" läßt sich die von R\&A in Deutschland geleistete Arbeit praktisch lükkenlos rekonstruieren ${ }^{25}$. R\&A/Germany war in zwei Hauptkomponenten aufgeteilt:

22 "Position of Anti-Nazi Groups in Krefeld“; „Notes on the Political Role of Military Government ${ }^{\alpha}$, s.o. Anmerkung 9.

${ }^{23}$ NA, RG 226, E 1, b 1, f 15: „JCS 1035: OSS Mission to Germany“, 13.9. 1944; vgl. auch Langer an McGovern, 18. 8. 1944, „Post-Hostilities Problems of Military Import“, sowie den „Plan for R\&A Work in Germany“ vom 10.9. 1944 in b 16. Außerdem: NA, RG 226, E 1, b 1, f 3, Europe-Africa Division, Rechenschaftsbericht 1944/45, sowie die Unterlagen in NA, RG 226, E 74, b 2, f: Germany/OSS Mission/Plans.

24 Siehe die Korrespondenz zwischen Dezember 1944 und Februar 1945 in NA, RG 226, E 1, b 16 (JCS 1035/1,2); vgl. auch OSS War Report II, S.327.

25 In: NA, RG 226, E 1, b 16: OSS Mission for Germany, European Theater of Operations, R\&A/ Germany, Juni 1945 - Dezember 1945, bzw. ab November als Strategic Services Unit, War De- 
Das in einige parallel zu R\&A/Washington gebildete Unterabteilungen wie IDC, Biographical Records und CID gegliederte Intelligence Services Department hatte Hintergrundinformationen und dokumentarische Materialien wie z. B. Unterlagen von NSOrganisationen zu sammeln; während das Intelligence Studies Department für die Sammlung aktueller Informationen und Materialien durch „field teams“ und die Ausarbeitung von Berichten und Analysen zuständig war. Dieses Organisationsschema mußte allerdings schon im August wegen drastischer Budgetkürzungen gestrafft werden, wobei vor allem der von anfänglich etwa 40 Mitarbeitern auf über 90 angewachsene Personalstab wieder reduziert wurde, obwohl seit August auch ein R\&A-Stab in Berlin stationiert war, der die Zusammenarbeit mit den dortigen amerikanischen Besatzungsbehörden erleichtern sollte.

Da R\&A mitnichten die einzige Abteilung war, die im Deutschland der unmittelbaren Nachkriegszeit mit der Sammlung von „intelligence“ befaßt war, wollte sich R\&A/Germany auf einen Bereich spezialisieren, in dem man sich besonders kompetent glaubte, und vor allem über "political forms, organizations and leaders" berichten $^{26}$. R\&A wollte dabei versuchen, „to construct as accurately as we can the political pattern as it exists and as we think it is going to evolve in Germany". Die dabei gesammelten Informationen sollten in „Field Intelligence Studies“ (FIS) zusammengefaßt und analysiert werden ${ }^{27}$.

Obwohl man den Ehrgeiz hatte, diese Field Intelligence Studies zur "specialité de maison" zu machen, scheint die Nachfrage nach manchen schon bekannteren R\&A„Spezialitäten“ zunächst einmal größer gewesen zu sein. Insbesondere die Arbeit der Biographical Records Section erfreute sich offenbar immer größerer Wertschätzung, seit amerikanische Truppen im Herbst 1944 nach Deutschland eingerückt waren ${ }^{28}$. Bereits Mitte November hatte Chandler Morse, Chef von R\&A/ETOUSA, berichtet, daß sich die militärischen Nachrichtenstäbe geradezu enthusiastisch über die von Biographical Records ausgearbeiteten Berichte geäußert hätten, wobei nur bedauert worden sei, daß die entsprechenden Karteien nicht umfangreicher seien, da Informationen dieser Art von zentraler Bedeutung für die Besatzungstruppen seien. Morse berichtete, ,[that] the availability of personality files is one of the chief topics of conversation in every in-

partment, Mission to Germany, USFET, Progress Report, R\&A Germany. Zur Organisation der Abteilung vgl. „Organization of R\&A/Germany", Chandler Morse an William Langer, 19.2. 1945, in: NA, RG 226, E 1, b 16, und ebenda, Research and Analysis Branch, Office of Strategic Services Mission for Germany, Branch Order No 2, „Organization of R\&A/Germany“, 22.6. 1945.

${ }^{26}$ NA, RG 226, E 1, b 16: R\&A/Germany - Bericht von Chandler Morse (Chief, R\&A/ETO) über Konferenz vom 25. bis 28. 6. über Arbeitsprogramm von R\&A/Germany; vgl. auch Progress Report R\&A/Germany vom 1.7. 1945, ebenda.

27 Einige dieser Field Intelligence Studies sind abgedruckt bei Borsdorf/Niethammer (Hrsg.), Zwischen Befreiung und Besatzung. Eine Auflistung aller von R\&A/Germany ausgearbeiteten FIS findet sich in den Progress Reports, R\&A/Germany (vgl. auch Anhang). Außer an den von Borsdorf/Niethammer angegebenen Fundstellen finden sich die FIS fast vollständig in der Lerner Collection der Hoover Institution, Stanford, CA, b 48; siehe außerdem NA, RG 226, OSS Field Intelligence Studies $(1 \mathrm{~b})$. Einige FIS werden auch erwähnt von Wuermeling, Die Weiße Liste, S. $254 \mathrm{ff}$.

${ }^{28}$ Dazu und zum Folgenden NA, RG 226, E 1, b 2, f: CID, Biographical Records Section, 1944: Schreiben von Chandler Morse, Chief, R\&A ETOUSA, und T.W. Reese (HQ \& HQ Detachment, OSS, ETOUSA, US Army-Main) an R\&A-Chef Langer, 13.11. 1944. 
telligence meeting. We are the only US agency servicing the various customers in the Theater and in some categories we are the only agency supplying accurate and complete information to G-2, G-5 and CC. [.. .] the various customers not only appreciate what we have done, but they are looking to us with an expectancy that is almost desperate."

Das Arbeiten vor Ort bot Biographical Records seit Mai 1945 die Möglichkeit, bisher angelegte Karteien zu ergänzen; zudem begann man nun, Karteien über die von den Militärregierungen eingesetzten Stelleninhaber aufzubauen ${ }^{29}$. In zunehmendem Maße lieferte Biographical Records den regionalen MG-Stellen sowie dem US Group Control Council (USGCC) biographische Informationen, wobei neben Auskünften über einzelne auch „weiße Listen “ zusammengestellt wurden ${ }^{30}$.

Eine weitere wichtige Funktion von R\&A/Germany war gerade in der unmittelbaren Nachkriegszeit die Sicherstellung von Dokumenten ${ }^{31}$. Die eigens für diese Aufgabe gebildeten Arbeitsgruppen suchten auf zahlreichen "field trips" vorher festgelegte Zielorte auf, um dort vermutete Materialien sicherzustellen. Im Rahmen dieser Aktionen wurden beispielsweise umfangreiche Bestände der I.G. Farben entdeckt, und zwei nach Leipzig entsandte R\&A-Mitarbeiter stießen auf ,a wealth of important material on pre-VE-day resistance and underground activities, particularly in association with the role of Dr. Goerdeler “ ${ }^{32}$. Besonders hektische Aktivität verzeichnet der Progress Report vom 1.Juli für den vorausgegangenen Monat: „The pace of operation was considerably accelerated by the necessity of exploiting rapidly deposits in areas that were only temporarily under American control.“ Mit Unterstützung des Militärs wurde eine Sonderaktion organisiert, um Unterlagen aus Sachsen und Thüringen zu evakuieren; unter anderem wurden dabei Materialien der Zeiss-Forschungsbibliothek sowie Akten des deutschen Auslandsinstituts sichergestellt. Kaum weniger wichtig war schließlich die Sammlung von Dokumenten und Unterlagen, die als Beweismaterial bei den geplanten Kriegsverbrecherprozessen dienen konnten ${ }^{33}$.

Nach den ersten, etwas hektischen Wochen konnte sich R\&A/Germany schließlich verstärkt der Berichterstattung über die politischen, wirtschaftlichen und gesellschaftlichen Entwicklungen im besetzten Deutschland zuwenden. Auf „field trips“ führten R\&A-Mitarbeiter zahllose Gespräche mit Deutschen und Vertretern lokaler MG-Einheiten, sammelten alle erdenklichen Informationsmaterialien und notierten ihre Beobachtungen. Diese Informationen gingen zum einen als "raw intelligence“ an R\&A/ Washington, um dort weiterverarbeitet $\mathrm{zu}$ werden $^{34}$, zum anderen wurden sie teilwei-

29 Vgl. dazu NA, RG 226, E 1, b 16, R\&A/Germany Progress Report vom 1.6. 1945, sowie NA, RG 59, R\&A 31 97.1-5: „Principal Post-Nazi German Officials“, August 1945 - März 1946; NA, RG 59, R\&A 3474.1-3: „The Principal Political Leaders in Occupied Germany“, 12.3. 1946.

30 NA, RG 226, E 1, b 16, R\&A/Germany Progress Reports vom 1.6. bis 1.9. 1945. Biographical Records arbeitete im August beispielsweise eine umfassende Namensliste geeigneter Kandidaten für hohe Verwaltungsämter aus, die Allen Dulles zur Vorlage beim USGCC angefordert hatte; vgl. dazu auch Gilbert, Lehrjahre im alten Europa, S.213; sowie den Hinweis auf eine für das State Department ausgearbeitete Liste in NA, RG 226, E 50, b 1.

${ }^{31} \mathrm{Vgl}$. in diesem Zusammenhang auch die bei Gilbert geschilderte Entdeckung des Archivs des Auswärtigen Amtes: Gilbert, Lehrjahre im alten Europa, S. $205 \mathrm{ff}$.

${ }^{32}$ NA, RG 226, E 1, b 16, R\&A/Germany Progress Report vom 1.6. 1945.

${ }^{33}$ Dazu ausführlicher im 2. Teil dieses Kapitels.

34 Vgl. dazu z. B. die Materialien in NA, RG 226, E 50, b 1; freilich war man in R\&A/Washington - insbesondere in der Economics Division - nicht immer mit dem Umfang der von R\&A/Ger- 
se schon von den in Deutschland stationierten R\&A-Mitarbeitern ausgewertet. Zuweilen sind diese Berichte nicht viel mehr als Bestandsaufnahmen, die ohne eingehendere Analysen einen Ausschnitt der spezifischen Situation an einem bestimmten Ort nachzeichnen $^{35}$. Mehr und mehr wurde dann in den Field Intelligence Studies (FIS) versucht, lokale und regionale Strukturen deutlicher herauszuarbeiten und einzelne gesellschaftliche Gruppen oder Institutionen und ihre politische Haltung zu untersuchen ${ }^{36}$. In R\&A hatte man sich selbst im Verdacht, dabei die gemäßigte Linke, insbesondere gewerkschaftliche Gruppen und die Sozialdemokratie, anfänglich in den Vordergrund gestellt zu haben. Für Juli und August nahm man sich deshalb vor, verstärkt über andere gesellschaftliche Gruppen zu berichten: mehr Aufmerksamkeit sollte nun kirchlichen Aktivitäten geschenkt werden, was, insbesondere für Bayern, „logically under the right-wing category " falle ${ }^{37}$; von einer Untersuchung des politischen Klimas an den Universitäten erhoffte man sich Aufschlüsse über „academic attitudes“ sowie „intentions and activities of middle class groups ${ }^{* 38}$.

Daneben beteiligte sich R\&A an der Ausarbeitung umfassender Lokalstudien ${ }^{39}$. Mitte August begann eine Gruppe von R\&A-Mitarbeitern in Zusammenarbeit mit der In-

many gelieferten Daten und Informationen zufrieden. In Washington während dieses Zeitraums ausgearbeitete Studien sind z. B.: NA, RG 59, R\&A 3426, „The Land Reform in the Soviet Zone of Germany: Social and Political Implications", 5.11. 1945; NA, RG 59, IRIS/(R\&A) 3383, "The German Standard of Living and Industrial Capacity Available for Reparations", 6.12. 1945, (Draft), sowie die überarbeitete Version vom 30.1. 1946; NA, RG 59, IRIS/(R\&A) 3370, "Observations on the Ruhr Coal Situation in the Summer and Fall of 1945", 21.12. 1945; NA, RG 59, IRIS/(R\&A) 3371, „The Ruhr: Problems of Boundary Delimitation“, 11.12. 1945.

${ }^{35}$ Die während oder nach den "field trips“ ausgearbeiteten Aufzeichnungen sind als „Spot Intelligence Reports" in den R\&A Progress Reports aufgelistet. Vgl. dazu und zum Folgenden auch NA, RG 226, E 50, b 1, H. Stuart Hughes an Chandler Morse und Harold Deutsch: „Work Program of R\&A Branch to 15 August 1945“, 5.7.1945.

${ }^{36}$ Wie auch schon Katz, Foreign Intelligence, S. 175, festgestellt hat, sind die FIS jedoch ebenfalls eher historische Dokumentationen als politische Analysen; eben dies hat Borsdorf/Niethammer veranlaßt, sie als Dokumente der deutschen Geschichte „zwischen Befreiung und Besatzung“ herauszugeben.

37 Es scheint aber später keine entsprechende FIS ausgearbeitet worden zu sein; Anfang Januar 1946 erschien jedoch NA, RG 59, ORI/(R\&A) 3388, "The Churches and Political Life in Post-War Germany“, 2.1. 1946.

38 Vgl. NA, RG 226, E 1, b 16, R\&A/Germany Progress Report vom 1.8. 1945; FIS 21, „The Liberal Universities of Baden, I. Freiburg“', 20.9. 1945, in: Hoover Inst., Lerner Collect., b 48; FIS 41, "The Liberal Universities of Baden: II. Heidelberg", 13.11. 1945 (verzeichnet in NA, RG 226, E 1, b 16, R\&A/Germany Progress Report vom 1.12. 1945, nicht aufgefunden). An der Ausarbeitung dieser Studie war der gebürtige Badener Felix Gilbert maßgeblich beteiligt, vgl. dazu seine Memoiren: Lehrjahre im alten Europa, S.214ff.; siehe auch Katz, Foreign Intelligence, S.88ff., der zu Recht das aus dieser Arbeit sprechende „Befremden“ des über seine ehemalige Heimat berichtenden Emigranten hervorhebt. Vgl. im übrigen die früheren, noch spekulativen Ausführungen zu „Trends in German Intellectual Life“, European Political Report, Vol. II, No. 14, 6.4. 1945, in RG 243, E 36, b 96 (155).

39 NA, RG 59, IRIS/(R\&A) 3298, Field Memorandum 1010, Germany [Biebrich] 24.10. 1945, "Darmstadt: A Survey of Political, Economic and Social Conditions in a Medium-Sized German City“, 29.12. 1945; laut NA, RG 226, E 1, b 16, R\&A/Germany Progress Report vom 1.11. 1945 als FIS 34 erschienen. Auch in der historischen Forschung ist später versucht worden, mit Hilfe solcher Lokalstudien Einsichten in die politischen und sozialen Strukturen der Besatzungszeit zu gewinnen, siehe z. B. Gimbels Arbeit über Marburg: A German Commu- 
formation Control Division (ICD), USFET, die politischen, wirtschaftlichen und sozialen Verhältnisse in Darmstadt zu untersuchen. Dabei wurden mehr als 200 Darmstädter Bürger aus verschiedenen sozialen Gruppen eingehend befragt, und Jugendliche und Erwachsene wurden aufgefordert, in Fragebögen Auskunft über ihre politische Haltung zu geben. Darüber hinaus wurden ausführliche Gespräche mit 30 Nationalsozialisten geführt, die von der Militärregierung entlassen worden waren. Schließlich wurden alle irgendwie zugänglichen Materialien, Dokumente und Statistiken ausgewertet. Auf dieser Basis entstand eine Studie, in der auf über 200 Seiten ein detailliertes Bild des schwierigen Nachkriegsalltags in einer einstmals überdurchschnittlich wohlhabenden, nun aber zu drei Vierteln zerstörten Stadt gezeichnet wird. Untersucht wurden dabei nicht nur die materiellen Zerstörungen, sondern auch die Auswirkungen von NS-Diktatur und Krieg auf die Gesellschaft, auf Familienstrukturen und auf den einzelnen. Besonderes Interesse galt in diesem Zusammenhang der Frage, inwieweit nationalsozialistisches Gedankengut in den verschiedenen Gesellschaftsgruppen fortwirkte ${ }^{40}$. Obwohl diese Studie so ein recht differenziertes Bild vermitteln konnte, beschrieb auch sie wieder eine politisch weitgehend apathische, von den täglichen Existenzsorgen der Gegenwart absorbierte Bevölkerung.

Abgesehen von solch umfassenden Lokalstudien vermitteln die einzelnen Berichte von R\&A/Germany notwendigerweise ein eher fragmentarisches Bild. Fragmentarisch mußte dieses Bild vor allem deshalb bleiben, weil diese Berichte eine Übergangsphase dokumentieren - eine Übergangsphase, die zudem insofern ein völliges Novum darstellte, als ein Staat nach seiner „bedingungslosen Kapitulation“ von den Siegermächten besetzt worden war und als staatliches Gebilde zu existieren aufgehört hatte, wobei offenblieb, wie, wann und in welcher Form er wieder rekonstruiert werden sollte. Fragmentarisch mußte das in den R\&A-Berichten vermittelte Bild aber auch deshalb bleiben, weil die von den Siegermächten etablierte Zoneneinteilung viele Entwicklungen tatsächlich in einem ganz wörtlichen Sinne fragmentierte.

In dieser Situation waren auch die Mitarbeiter von R\&A/Germany auf die Rolle des "Lokalberichterstatters" verwiesen und kaum in der Lage, übergreifende Tendenzen und Strukturen - so sie sich überhaupt entwickeln konnten - zu erkennen. Der Ehrgeiz von R\&A, „to construct as accurately as we can the political pattern as it exists and as we think it is going to evolve in Germany", erwies sich insofern als überzogen. Letztlich mußten die Berichte aus Deutschland die Ungewißheit der Situation - nicht nur aus deutscher, auch aus amerikanischer bzw. alliierter Perspektive reflektieren. Gleichwohl lassen sie in der Gesamtschau gewisse Tendenzen und Strukturen, durchaus auch "political patterns“ dadurch erkennbar werden, daß sich bestimmte Beobachtungen und Eindrücke wiederholten und sich so zu „patterns" verdichteten.

nity under American Occupation, sowie die vor allem seit Anfang der achtziger Jahre entstehenden sozial- und allragsgeschichtlichen Forschungen, z. B. Niethammer (Hrsg.), „Hinterher merkt man"; Woller, Gesellschaft und Politik in der amerikanischen Besatzungszone; Broszat/ Henke/Woller (Hrsg.), Von Stalingrad zur Währungsreform.

${ }^{40} \mathrm{Vgl}$. dazu auch NA, RG 226, 1405 69, US Group Control Council, Information Control Service, Information Control Intelligence Summary \#3, Week ending 27 July 1945 (Annex: German Youth: A Preliminary Study); sowie die Arbeit des ehemaligen ICD-Mitarbeiters Rodnick, Postwar Germans. 
Wenn sich R\&A dabei im Verdacht hatte, der Entwicklung von Gewerkschaften und Sozialdemokratie besondere Aufmerksamkeit zukommen zu lassen, so war dieser Verdacht durchaus gerechtfertigt. Obwohl man sich bemühte, diese Themen nicht zu dominant werden zu lassen, beobachtete man die Entwicklungen in diesem gesellschaftlichen und politischen Spektrum doch immer mit besonderem Interesse. Das war insofern nur konsequent, als R\&A erwartet hatte, daß es innerhalb der deutschen Gesellschaft vor allem diese Gruppen sein würden, die den Aufbau eines demokratischen Nachkriegsdeutschland vorantreiben und entscheidend gestalten würden. Dementsprechend hatte R\&A im Rahmen der Arbeiten für das War Department immer wieder dafür plädiert, diese Kräfte gewähren zu lassen bzw. sie zu unterstützen. Schon in den ersten Monaten der Besatzung schienen sich aber die von R\&A immer wieder geäußerten Befürchtungen zu bewahrheiten, daß die Militärregierung statt dessen - „by a misguided emphasis on achieving ends that can be attained only by strengthening the power of the traditional ruling groups ${ }^{\star 41}$ - die Handlungs- und Wirkungsmöglichkeiten dieser Gruppen beschneiden würde. Wie bereits angedeutet, reagierte R\&A darauf zunächst zurückhaltend und äußerte nur indirekte Kritik. So lassen weder die von R\&A/Germany im weiteren Verlauf des Jahres 1945 ausgearbeiteten Berichte noch die auf diesen Meldungen basierenden Arbeiten von R\&A/Washington eine so eindeutige Parteinahme zugunsten der Linken erkennen, wie sie R\&A zuweilen unterstellt worden ist ${ }^{42}$. Nur bedingt gerechtfertigt scheint mithin die Feststellung, „daß diese Analysen in Methode und Wertung der europäischen Arbeiterbewegung weit näher standen als die amerikanische Politik im ganzen"; wie zu zeigen sein wird, standen diese Analysen und Berichte der deutschen Arbeiterbewegung durchaus kritisch gegenüber, und wenn sie ihr doch näher stehen mochten „als die amerikanische Politik im ganzen“, so sprach aus ihnen auch immer wieder eine Distanz, die wohl in vielen Fällen die ganz wörtlich zu nehmende „Entfremdung " des Emigranten angesichts einst vertrauter, nun völlig veränderter - und zudem von einem Veränderten wahrgenommener - Verhältnisse reflektierr ${ }^{43}$.

Dennoch, oder vielleicht gerade deshalb, betonen diese R\&A-Berichte immer wieder Kontinuitätslinien, die entweder als Folge oder Fortsetzung der jüngsten deutschen Geschichte oder als Anknüpfen an die von ihr unterbrochenen Entwicklungen der Weimarer Republik beschrieben werden. So wird das von den Besatzungstruppen vor-

${ }^{41}$ Siehe dazu oben V., 1. Teil.

${ }^{42}$ Neben Söllner (Hrsg.), Archäologie der Demokratie, dessen dahin gehende Thesen bereits mehrfach angesprochen wurden, auch Borsdorf/Niethammer (Hrsg.), Zwischen Befreiung und Besatzung, insbesondere S.16 (daraus auch das nachfolgende Zitat); und außerdem - zumindest für die Arbeit der „Frankfurter Schule“ - Katz, Foreign Intelligence, insbesondere S. 33 ff., vgl. jedoch auch S. $50 \mathrm{f}$. und $90 \mathrm{ff}$., wo Katz für 1945 ebenfalls eine gewisse Ernüchterung feststellt.

${ }^{43}$ Vgl. dazu die Schilderungen von Herz, Vom Überleben, S. $140 \mathrm{ff}$., und Gilbert, Lehrjahre im alten Europa, S. $201 \mathrm{ff}$ - Zudem ist zu berücksichtigen, daß die R\&A-Berichte aus Deutschland nicht durch die abteilungsinternen "Zensurinstanzen " des Projects Committee in R\&A/Washington gingen und insofern nicht unbedingt die von der Abteilung vertretenen Positionen widerspiegeln, sondern u.U. eine ganz individuelle Sichtweise vermitteln. Nicht zuletzt deshalb wird hier weniger auf einzelne Berichte eingegangen, sondern versucht, einige allgemeine Tendenzen dieser Berichte zu skizzieren und schließlich zu verfolgen, wie diese Berichte in R\&A/ Washington bzw. in der R\&A-Publikation European Political Report weiterverarbeitet wurden. 
gefundene Chaos zwar als tiefgehender Einschnitt dargestellt, doch die Auflösung staatlicher, politischer, wirtschaftlicher und gesellschaftlicher Strukturen wird auch sogleich als Erbe des Nationalsozialismus begriffen. Daß dessen Gedankengut sich nicht gleich mitaufgelöst hatte, sondern in den Köpfen vieler, die diese „Zusammenbruchgesellschaft" ausmachten, weiterwirkte, wird als selbstverständlich vorausgesetzt. Immer wieder wird die Bevölkerung als weitgehend apathische, von der Sorge ums nackte Überleben absorbierte und gleichzeitig autoritätshörige „Masse" beschrieben, für die es eine "Stunde Null" nicht gab: "[The] impression of the mass of the Germans is one of almost complete apathy. Years of Nazi rule have schooled them to await orders and not to exercise any initiative; they will await and execute orders of MG in much the same fashion, for some time to come, as they once did for the Nazis. " 44

Enttäuschend mußte es für $R \& A$ freilich sein, daß auch die Linke wenig Initiative zeigte. In R\&A/Germany glaubte man, daß diese zuweilen als Paralyse beschriebene Passivität ebenfalls durch Kontinuitäten zu erklären sei, die man so freilich kaum erwartet, wenn auch zuweilen schon befürchtet hatte. Fast einfühlsam, aber dennoch nicht unkritisch, beschreibt Anfang Juni ein Artikel in dem von R\&A für die in Europa stationierten Truppen herausgegebenen Nachrichtenmagazin European Political Report (EPR) den Zustand der deutschen Sozialdemokratie in der unmittelbaren Nachkriegszeit ${ }^{45}$.

Bezeichnenderweise wird einleitend zunächst einmal die lange und ereignisreiche Geschichte der SPD beschworen, ohne die man, wie versichert wird, den gegenwärtigen "status" der deutschen Sozialdemokratie nicht verstehen könne, da sich die meisten deutschen Arbeiter, die noch vor Hitlers Machtübernahme ins Erwachsenenalter kamen, voll Stolz dieser Tradition bewußt seien. Das Ansehen der SPD habe zwar durch die Haltung der Partei im Ersten Weltkrieg gelitten, und die Spaltung der deutschen Sozialisten sowie der Sozialistischen Internationale hätte sich ebenfalls negativ ausgewirkt; überdies habe das Aufkommen des Faschismus in Deutschland viel zur Diskreditierung der Partei beigetragen; dennoch sei sie bis zu ihrer Unterdrückung durch die Nationalsozialisten schlechthin die Massenorganisation der deutschen Arbeiterschaft geblieben - „commanding the unquestioning loyalty of many millions of voters and disposing over a huge apparatus of trained functionaries, office buildings and meeting halls, and journals of every description".

All dies hätten die Nationalsozialisten nach ihrer Machtübernahme zerstört oder an sich gerissen: „The SPD's leadership was dispersed or killed off; its buildings and assets were confiscated. Physically and organizationally, the continuity of its history was violently and completely interrupted." Die aus Geschichte und Tradition der SPD erwachsende Identität war damit nach Darstellung von R\&A aber noch nicht zerstört: „[The] Social Democratic Party lived on as a memory and as an idea in the minds of German workers. It was not an idea which could grow and develop; it was fixed into a rigid pattern. [...] Under Hitler, Social Democracy lived on entirely because of its great past, not at all because of its role in the present." Nun, nach der Beseitigung des NS-

44 Hier aus NA, RG 226, E 108, b 8, f 60: „Comprehensive Report of Trip through Germany“, 18.6. 1945; viele andere Berichte äußern sich ganz ähnlich, vgl. z. B. oben den Lunning-Bericht S.171f.

45 „German Social Democracy Today“, European Political Report, 8.6. 1945, Vol. II, No. 23, Hoover Inst., Lerner Collect., b 48. 
Regimes, glaubte man in R\&A beobachten zu müssen, daß sich die Sozialdemokratie nur mühsam aus ihrer erzwungenen Erstarrung lösen könne: „[Now,] unlike the situation which has prevailed for the past 12 years, the Social Democrats are finding themselves in a position where they have to make decisions and take action. [. . .] in the completely different situation which faces them today [...] the Social Democrats have no clear sense of direction [. . . Socialism as a political philosophy and as an ultimate goal remains, but Socialism as a practical program has virtually disappeared in Germany."

In dieser Situation glaubte R\&A, einige für die Sozialdemokratie typische Verhaltensmuster beobachten zu können, von denen zwei der Abteilung als möglicherweise entscheidend für die künftige Entwicklung der Partei schienen. Das eine beschrieb R\&A als "Traditionalist Trend", das andere als "United Front Trend". Wie die Bezeichnung "Traditionalisten" schon andeutet, orientierte sich diese Gruppe nach Ansicht von R\&A an den traditionellen Konzeptionen der Partei und blieb damit, wie impliziert wurde, überkommenen Vorstellungen verhaftet: „[They] would like to deal with the problems of the present pretty much as they dealt with the problems of the past." Nach Darstellung von R\&A neigten die "Traditionalisten“ dazu, enge Zusammenarbeit mit der Militärregierung zu suchen und von ihr Unterstützung zu erwarten; nicht zuletzt erwarteten sie von Briten und Amerikanern, „to halt the expansion of Soviet influence, preferably at the eastern borders of Germany". Die Vertreter des „United Front Trend“ suchten dagegen nach neuen Ansätzen, denn sie seien der Überzeugung, "that the traditional methods and instruments of Social Democracy are either not strong enough or not appropriate for the solution of the problems which the Nazi regime has left behind“. Die "antifascist societies“, in denen sie sich organisierten, seien ein Versuch, "to improvise new tools and new techniques“. Diese "Aktivisten“ sähen in einer gründlichen Entnazifizierung das dringlichste Problem und betrachteten die Besatzungsmächte dabei "as a hindrance rather than a help“.

R\&A war sich nicht sicher, ob daraus notwendigerweise eine Spaltung der Sozialdemokratie erwachsen würde, da diese beiden Gruppen durchaus als komplementär betrachtet werden könnten: „[The] old officials prepare the ground for a revival of Social Democratic institutions and represent the movement's interests with the occupying authorities, while the activists work with the masses and preserve the good name of the SPD with the rank-and-file." In welche Richtung sich eine wiederbegründete SPD letztlich entwickeln würde, war nach Ansicht von R\&A noch nicht abzusehen, da dies davon abhänge, welche Gruppe innerhalb der Partei eine Mehrheit gewinnen würde.

Ähnlich wie in früheren Berichten erscheint die SPD zwar auch hier wieder merkwürdig gelähmt, doch wird dies nicht länger mit der fast völligen Vernichtung ihrer politischen Funktionäre erklärt. Ausdrücklich wird vielmehr darauf verwiesen, daß überraschend viele von ihnen überlebt hätten. Doch auch sie scheinen unfähig, die ihnen jahrelang aufgezwungene politische Passivität zu überwinden ${ }^{46}$, geschweige denn der

${ }^{46}$ Vgl. in diesem Zusammenhang auch den EPR-Artikel „Views of a Left-Wing German Catholic ${ }^{*}$ vom 13.4. 1945 (European Political Report, Vol. II, No. 15, in: RG 243, E 36, b 96 (155)), wo noch betont worden war, daß offenbar nur wenige Linke überlebt hätten: "some of the few leftist figures who have been found seem to be suffering from a sort of mental paralysis produced by the combination of political persecution, wartime strain, and almost complete isolation both from one another and from the outside world. ${ }^{*}$ 
Partei neue Impulse zu geben. Als politische Kraft, die für die von R\&A für so unabdingbar gehaltene sozialistisch-demokratische Erneuerung Deutschlands streiten könnte, drohte die Partei, die einst auf die unbedingte Loyalität von Millionen von Wählern zählen konnte, damit auszufallen.

In den Wochen nach dem Erscheinen dieses Artikels war man auch in R\&A/Washington mit der Ausarbeitung einer Studie zur "Social Democratic Party of Germany “ beschäftigt ${ }^{47}$, und bezeichnenderweise entzündete sich an dieser Arbeit eine erbitterte Kontroverse, die sich - will man die Terminologie des EPR-Artikels aufnehmen - als eine Auseinandersetzung zwischen "Traditionalisten“ - nämlich den Verfassern der Studie - und Vertretern des „United Front Trend“ - ihren Kritikern - beschreiben lie$\mathrm{Be}^{48}$. Die R\&A-„Zensoren“ des Projects Committee hatten den ihnen vorliegenden Entwurf dieser Arbeit scharf kritisiert und in Zweifel gezogen, ob sie als objektiv und wissenschaftlich fundiert gelten könne. Ihre mehrere maschinenschriftliche Seiten umfassende Kritik zielte in fast allen Punkten darauf ab, daß da, wo die SPD als Arbeiterpartei mit der KPD verglichen wurde, mehrfach in verzerrender Weise Statistiken, Daten und Ereignisse zugunsten der SPD und auf Kosten der KPD ausgewählt oder interpretiert worden seien. Zudem wurde kritisiert, daß die SPD immer wieder als der sozusagen kongeniale - nämlich zutiefst demokratische und verläßlich antikommunistische - Partner der Militärregierung dargestellt wurde, während die Frage nach einer eventuellen Kooperation zwischen SPD und KPD nicht angemessen problematisiert würde, wobei die Kritiker auch bemängelten, daß nicht in Rechnung gestellt worden sei, welche Konsequenzen sich aus der zu erwartenden Stärke der Kommunisten in der sowjetischen Besatzungszone ergeben könnten.

$\mathrm{Da}$ der hier so scharf kritisierte Entwurf nicht aufgefunden werden konnte, läßt sich nicht feststellen, inwieweit er tatsächlich überarbeitet wurde. Der am 1.September schließlich herausgegebene Bericht läßt allerdings vermuten, daß die meisten dieser Kritikpunkte berücksichtigt wurden. Nach einer Darstellung der charakteristischen Strukturen und traditionellen Positionen der SPD sowie einem Abriß über die SPD in Exil und Widerstand wird im Hauptteil dieses Berichts versucht, Entwicklung und Chancen der SPD in der Nachkriegszeit einzuschätzen. Dabei wird bereits zwischen den drei westlichen Zonen einerseits und der sowjetischen Besatzungszone andererseits unterschieden, doch da R\&A zu dem Schluß kam, daß die SPD in der sowjetischen Besatzungzone wenig mehr als ein „Anhängsel“ der KPD war und auch künftig kaum Chancen hatte, sich als eigenständige Arbeiterpartei mit einer breiten Basis zu etablieren, liegt der Schwerpunkt auf der Darstellung der Entwicklungen in den westlichen Zonen.

Grundsätzlich erscheint die SPD - anders als in den ersten Berichten aus Deutschland - im Hinblick auf ihre Beteiligung an den von den Militärregierungen eingesetzten Verwaltungen nicht länger benachteiligt: „SPD functionaries and Party regulars have furnished a large number of anti-Nazi appointees to Allied Military Government

47 NA, RG 59, R\&A 1549, 1.9. 1945; vorher war in dieser Reihe schon ausgearbeitet worden: NA, RG 59, R\&A 1550, "The German Communist Party", 10.7. 1944; beide Studien in deutscher Übertragung in Söllner (Hrsg.), Archäologie der Demokratie, Bd.1, S.281-313, 260-280; vgl. zum Folgenden auch Klotzbach, Der Weg zur Staatspartei.

${ }^{48} \mathrm{Zu}$ dieser Kontroverse: NA, RG 226, E 1, b 3, f: Europe-Africa Division, Schreiben von Richard Hartshorne an Sherman Kent und Carl E. Schorske, "Criticisms of Political Reports", 17.7. 1945, bzw. ders. an dies., „R\&A No. 1549“, 14.7. 1945. 
positions. In September 1945 Social Democrats in the western zones were strongly represented on all levels of the administration. On an over-all basis, indeed, the SPD in this area has acquired more posts of all kinds than any other party [...] The Catholic Center Party follows the SPD as a weak second.“

Da die Anordnungen der Militärregierungen politische Aktivitäten noch stark einschränkten, sei das politische Programm der SPD erst in Umrissen zu erkennen. Die SPD sei bislang vor allem für eine gründliche Entnazifizierung eingetreten und kritisiere immer wieder, daß die Militärverwaltungen die Entnazifizierung nicht energisch genug vorantrieben. $\mathrm{Da}$ die Mehrheit der SPD-Anhänger nicht kompromittiert sei, habe sich die SPD gegen die von konservativen Kreisen befürwortete Beibehaltung sogenannter nomineller Nazis gewandt; tatsächlich benutze die SPD diese Position indirekt als Mittel im Kampf um politische Macht: „To the extent that the Social Democrats and leftist groups are able to classify their rightist opponents as Nazis, or Nazisympathizers, and to force the military government authorities to take action against them, their objective of winning power at a later date has been made easier to attain." Im übrigen setze sich die SPD für einen raschen Aufbau der Gewerkschaften ein, und SPD-Mitglieder schienen sich dafür bereits Führungsrollen zu sichern, obwohl sich auch die Gewerkschaften bislang noch nicht politisch betätigen konnten. Abgesehen davon, daß man den Aufbau einer Einheitsgewerkschaft anstrebe, zeichne sich ab, daß man größtenteils an traditionelle Strukturen anknüpfen wolle.

Auch für die Reorganisation der SPD scheine die Parteiführung am liebsten da anknüpfen zu wollen, wo sie 1933 hatte aufhören müssen. Die Mehrheit der SPD-Anhänger befürworte jedoch einen wirklichen Neuanfang, und so sei zu erwarten, daß Versuche, die Partei unter ihrer alten Führung wiederzubegründen, auf starken Widerstand stoßen würden. Gruppen, die sich im Exil und Widerstand von der SPD abgespalten hatten - wie Neu Beginnen, ISK und SAP -, hatten nach Einschätzung von R\&A allerdings keine Chancen, sich zu eigenständigen Parteien zu entwickeln.

Im Hinblick auf die Frage nach einer Zusammenarbeit zwischen SPD und Kommunisten wurde - eventuell in Anlehnung an den oben angesprochenen EPR-Artikel bzw. die auch darin verarbeiteten Feldberichte - zwischen zwei Haupttendenzen unterschieden: Eine Gruppe stehe einer derartigen Kooperation offen gegenüber und denke sogar an den Aufbau einer geeinten Arbeiterpartei, da sie in der Spaltung der Arbeiterklasse einen wesentlichen Grund für die erfolgreiche Machtübernahme der Nationalsozialisten sähe; die andere Gruppe lehne eine solche Kooperation oder gar einen Zusammenschluß dagegen strikt ab. Die in den Antifa-Ausschüssen bereits praktizierte Kooperation wurde von R\&A nun allerdings kritisch beurteilt. Nach Ansicht von R\&A hatte sie sich bereits als nicht wirklich tragfähig erwiesen, da traditionelle politische Divergenzen nur vorübergehend zurückgestellt werden konnten und bald wieder erkennbar geworden seien. So glaubte R\&A insgesamt konstatieren zu können, daß mit dem Zusammenbruch des NS-Regimes allgemein ein Wiederaufleben der während der Weimarer Republik geprägten Strukturen zu beobachten sei: „[As] the process of de-Nazification has stripped the Hitlerian layers from the structure of German society, its preNazi shape has begun to appear once more. ${ }^{49}$

49 Das war freilich ein Bild, das sich mit den R\&A-Analysen zum nationalsozialistischen Deutschland ganz und gar nicht vereinbaren ließ - gerade die Vorstellung, daß das NS-Regime 
Das erneute Hervortreten der parteipolitischen Linien der Weimarer Zeit ließ nach Beobachtung von R\&A auch die alten Auseinandersetzungen innerhalb der Linken wiederaufleben. Dementsprechend rechnete man in der Abteilung nicht mit einer einheitlichen Arbeiterpartei aus SPD und Kommunisten. Die Aussichten für eine Wiederbegründung der SPD als der nichtkommunistischen Arbeiterpartei wurden als günstig beurteilt; zudem rechnete R\&A damit, daß die SPD auch nach links tendierende Kreise der bürgerlichen Mittelschichten und der ,intelligentsia“ ansprechen würde. Nach Ansicht von R\&A würde die wiederbegründete SPD aber weitgehend der alten Partei ähneln und sich nur da erneuern, wo es unerläßlich schiene: „Although the post-Nazi SPD is likely to resemble strongly the pre-Nazi party in composition and policy, its leadership will chiefly be new. The fact that the SPD is greatly compromised by its failure to resist effectively the rise of the Nazi movement will require large-scale jettison on the top layer - despite some sentiment in favor of the exiled leaders."

Implizit setzt sich in diesem Bericht über die deutsche Sozialdemokratie so die kritische Sicht fort, die auch in früheren Arbeiten immer wieder angedeutet worden war. Im Grunde wiederholte bzw. bestätigte R\&A hier die mehr als ein Jahr zuvor in dem Civil Affairs Guide zur „Policy Toward Revival of Old Parties and Establishment of New Parties in Germany " geäußerten Vermutungen, daß die wiederbegründete SPD in traditionellen Bahnen bleiben würde ${ }^{50}$. Doch was im Juli 1944 nur vermutet worden war, schien nun durch die sich abzeichnenden Entwicklungen bestätigt zu werden. Die von R\&A damals geäußerte Hoffnung, daß das Ende des Krieges in Deutschland politische Kräfte freisetzen werde, die der von R\&A als Vorbedingung für eine tiefgreifende Demokratisierung für unabdingbar gehaltenen sozialen Revolution den Weg bereiten würden, mußte damit als nichtig erscheinen. Zwar hatten sich diese Kräfte in den Antifa-Ausschüssen tatsächlich manifestiert, doch hatte nicht nur die Intervention der Militärregierung ihre politische Handlungsfähigkeit eingeschränkt. So wie R\&A es darstellte, war es auch die Unfähigkeit dieser Gruppen selbst, aus ihrem Antifaschismus einen einigermaßen stabilen und tragfähigen politischen Grundkonsens herzustellen, die sie letztlich zu einer ihre spontan akkumulierte politische Energie schnell aufbrauchenden Erscheinung reduzierte. Unübersehbar war schließlich auch, $\mathrm{daß}$ in den R\&A-Berichten aus Deutschland wenig darauf hindeutete, daß die nach einer tiefgreifenden Erneuerung strebenden Kräfte eine Mehrheit der Bevölkerung für ihre Ziele gewinnen könnten. Wenn R\&A immer wieder darauf bestanden hatte, daß es den Deutschen selbst überlassen bleiben müßte, die mit fundamentalen gesellschaftlichen Reformen verbundenen Probleme zu lösen, so mußte man in der Abteilung nun wohl erkennen, daß für die meisten Deutschen ganz andere Probleme im Vordergrund

nur eine Art Belag bildete, der einfach „abgekratzt“ werden könnte, hatte R\&A in der Diskussion um die amerikanische Besatzungspolitik schließlich immer wieder zurückgewiesen (vgl. oben V., 1. Teil). Es muß dahingestellt bleiben, ob es sich hier nur um einen Lapsus linguae handelte oder ob eine subtile Kritik an der Entnazifizierungspolitik angedeutet werden sollte; falls letzteres beabsichtigt war, war diese Kritik allerdings wohl zu subtil, um außerhalb von R\&A verstanden oder auch nur wahrgenommen zu werden. Im übrigen konstatieren auch viele andere R\&A-Berichte ein Wiederaufleben gesellschaftlicher und politischer Strukturen der Weimarer Republik.

so Siehe oben V., Teil 1. 
standen als soziale Reformen - es war vieles "so völlig anders“, als man es sich vorgestellt, so völlig anders, als man gehofft hatte ${ }^{51}$.

Das politische Engagement, das trotz des Strebens nach Objektivität in den R\&AArbeiten zur "deutschen Frage" immer erkennbar geblieben war, wich nun zunehmend einer kritischen Distanz: immer mehr zog sich R\&A auf die Rolle eines Beobachters zurück, der das Agieren und Reagieren der gesellschaftlichen und politischen Kräfte in Deutschland - der deutschen wie der alliierten - in ihrem komplexen Wechselspiel zu erfassen suchte, sich dabei mit keinem der Akteure identifizierte, sondern nur aufzuzeigen versuchte, welche Weichenstellungen ihre Handlungen bedingten. Zum Teil mag diese zunehmende Beschränkung auf die Rolle des Berichterstatters und Analytikers Ausdruck einer gewissen Resignation gewesen sein, die sich in R\&A auszubreiten schien, je mehr man erkennen mußte, daß man für Deutschland keine Alternative, sondern eine Utopie entworfen hatte. Vor allem hatten sich für R\&A aber Fragestellungen und Arbeitsbedingungen entscheidend geändert. Mit der Besetzung Deutschlands durch die Alliierten und der Stationierung von R\&A-Mitarbeitern in Deutschland fielen R\&A in einem sehr viel unmittelbareren Sinn als zuvor "nachrichtendienstliche" Aufgaben zu, denn die Abteilung hatte nun vor allem die tatsächlichen politischen Entwicklungen zu beobachten und zu analysieren. Das Ende des Krieges brachte zudem mit dem Abbau der Washingtoner Kriegsbürokratie auch die Auflösung des OSS, und obwohl R\&A vom State Department übernommen wurde, bedeutete das mitnichten die Integration der Abteilung in den Prozeß der Formulierung der amerikanischen Nachkriegspolitik. Mehr als zuvor sah sich R\&A bei der Ausarbeitung von Berichten und Studien gezwungen zu berücksichtigen, „[that] readers of our political reports commonly have a prior conviction on the subject under discus-

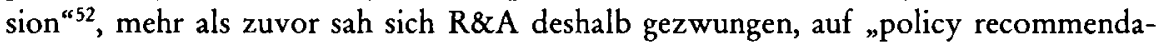
tions“ zu verzichten und sich auf die Rolle eines möglichst neutralen Berichterstatters und Analytikers zu beschränken.

Wie die Entwicklungen im Deutschland der unmittelbaren Nachkriegszeit unter diesen Gegebenheiten von R\&A dargestellt und beurteilt wurden, illustriert eine Anfang Januar 1946 fertiggestellte Studie zum „Revival of Political Life in Germany ${ }^{\text {c53, }}$ in der die bis Ende 1945 bei R\&A/Washington eingehenden Meldungen aus Deutschland verarbeitet wurden, so daß diese Arbeit eine Gesamtschau der von

${ }^{51}$ Dies vermitteln viele R\&A-Berichte aus Deutschland; vgl. auch Herz, Vom Überleben, S.140ff., und Gilbert, Lehrjahre im alten Europa, S.205, 210ff. Daß alles „so völlig anders“ war, als man es sich vorgestellt hatte, soll nach Gilberts Erinnerungen (in einem Interview im Zweiten Deutschen Fernsehen im November 1990) Franz Neumann während seines ersten Deutschlandaufenthalts im Herbst 1945 immer wieder festgestellt haben. Neumann war zu dieser Zeit als Mitglied der US-Delegation des Internationalen Militärgerichtshofes in Deutschland, vgl. dazu Herz, a. a. O.; Söllner (Hrsg.), Archäologie der Demokratie, Bd.1, S. 155; Katz, Foreign Intelligence, S. 54.

52 NA, RG 226, E 1, b 3, „Draft of proposed guide to preparation of political reports“, [o. D.], sowie ebenda, b 9, f: Political Reports (Preparation of): „Guide to Preparation of Political Reports", 5.5. 1944.

53 NA, RG 59, ORI/(R\&A) 3200, 11.1. 1946 (Anhang: biographische Angaben zu führenden politischen Persönlichkeiten); in deutscher Übertragung gekürzt wiedergegeben in Borsdorf/Niethammer (Hrsg.), Zwischen Befreiung und Besatzung, S. 275-311. Einen Überblick über die Entwicklungen der unmittelbaren Nachkriegszeit bietet Benz, Potsdam 1945. 
R\&A/Germany zu diesem Thema ausgearbeiteten Field Intelligence Studies vermittelt.

Die bislang in Deutschland zu verzeichnende politische Aktivität wollte R\&A nur sehr bedingt als „spontaneous indigenous activity" verstanden wissen, denn nach Darstellung der Abteilung wurde jegliches politische Leben vorläufig noch durch eine Reihe von Faktoren massiv eingeschränkt. So könnten sich politische Aktivitäten unter den Bedingungen der Besatzungsherrschaft - und insbesondere angesichts der von den Besatzungsbehörden verordneten Beschränkungen - nur in sehr begrenztem Rahmen entfalten; gleichzeitig reduzierten die Lebensbedingungen der Nachkriegszeit mit ihren Zerstörungen und Versorgungsschwierigkeiten das Interesse an politischen Fragen und ließen statt dessen die Sorge um lebensnotwendige Grundbedürfnisse sehr viel wesentlicher erscheinen. In dieser Situation würden politische Aktivitäten von den direkten, offenen Ebenen wie Parteien und Gewerkschaften häufig auf indirektere, wie etwa Industrie- und Handelskammern, Verwaltungsorgane oder auch Kirchen verlagert.

Die Aufteilung Deutschlands in Besatzungszonen kompliziere diese Situation noch weiter. Schon zu diesem Zeitpunkt sah R\&A einen deutlich ausgeprägten Ost-WestAntagonismus 54 : „The differences in policy between the western powers on the one hand and the Soviet Union on the other shape almost all aspects of German political life and enter even into local issues." So sei auch schon eine grundverschiedene Entwicklung des politischen Lebens in den westlichen Zonen einerseits und der sowjetisch besetzten Zone andererseits zu beobachten, die, wie R\&A mehrfach betonte, in erster Linie die verschiedenen Interessen der Besatzungsmächte reflektiere ${ }^{55}$. Insofern sah die Abteilung das politische Leben in Deutschland vor allem als "reaction to an external stimulus" oder gar "as the implementation by the Germans of the orders concerning establishment of political parties".

Doch auch wenn der Einfluß der Besatzungsmächte als dominierend angesehen wurde, glaubte R\&A, einige allgemeine Tendenzen in allen Zonen erkennen zu können, die, wie impliziert wurde, als der spezifisch deutsche Beitrag zu betrachten seien. Besonders auffällig erschien R\&A das Wiederaufbrechen traditioneller Konflikte, die charakteristisch für die deutsche Gesellschaft seien: „[The] development of post-Nazi political life is to a high degree shaped by the traditional social and political conflicts which characterized German politics prior to the Nazi rise to power. The basic conflicts are those between the ,bourgeois' parties on the one hand and the labor parties

54 Söllner (Hrsg.), Archäologie der Demokratie, Bd.2, S.60f. behauptet dagegen, daß „die Analyse vom Januar 1946 die Wiedererstehung der alten Links-Rechts-Polarität herausstellt, der gegenüber der durch die Besatzungsmächte gesetzte Bedingungsrahmen eher im Hintergrund bleibt“. Er stellt dies einer Arbeit vom Juni 1946 gegenüber (NA, RG 59, ORI/(R\&A) 3736, siehe unten VIII., 1. Teil), in der er - als Ausfluß des beginnenden Kalten Krieges - „die Akzente [...] genau umgekehrt gesetzt" sieht. Der von Söllner in diesem Zusammenhang konstatierte, vermeintlich besonders frühzeitige „Perspektivenwechsel“, wäre, wie obiges Zitat belegt, allerdings noch mindestens sechs Monate früher anzusetzen (vgl. aber auch schon die weiter oben vorgestellte Arbeit über die SPD).

55 Als Beispiel führte R\&A an, ,[that] the high percentage of Communist office-holders in the eastern zone corresponds just as little to their popular strength as does their low percentage in the western zone“. Ebensowenig rechtfertigten die Gegebenheiten die unterschiedliche Politik gegenüber der Industrie durch die Westmächte einerseits und die Sowjetunion andererseits. 
on the other, and, within the labor parties, between the Social Democrats (SPD) and the Communists (CP).“

Unmittelbar nach dem Zusammenbruch des NS-Regimes seien diese Konflikte zunächst dadurch überdeckt worden, daß sich alle antifaschistischen Kräfte zusammengeschlossen hätten. Diese "Einheitsfront“ habe jedoch die nur unterdrückten traditionellen Gegensätze nicht lange überdecken können, denn einerseits habe sich im bürgerlichen Lager bald wieder der tiefverwurzelte Antikommunismus geregt, andererseits habe aber auch die Linke aus dem Widerstand gegen Nazismus und Faschismus keine tragfähige politische Einheit entwickelt und sei noch immer in Kommunisten und Sozialdemokraten gespalten. Obwohl sich die Kommunisten von früheren revolutionären Dogmen abgewandt hätten, würden sie weiterhin mit Moskau und sowjetischen Interessen identifiziert, und gerade die SPD habe ihr tiefes Mißtrauen gegenüber der „Communist conception of democracy“ nicht aufgegeben. Die SPD ihrerseits entwickle sich in den westlichen Zonen zum "protagonist of ,Western democracy" on the left" - wie R\&A bemerkte, „a role to which the party seems predestined by its long reformist and anti-revolutionary record“.

Obwohl die Konflikte aus der Zeit vor der NS-Machtübernahme als noch bzw. wieder so bestimmend dargestellt wurden, glaubte R\&A andererseits auch tiefgreifende Veränderungen in der Struktur des Parteienspektrums zu beobachten. Diese seien vor allem Ergebnis der Eliminierung der Parteien der extremen Rechten. Deren Verbot bewirkte nach Ansicht von R\&A freilich keineswegs eine Schwächung der Rechten, sondern, ganz im Gegenteil, ihre Stärkung, denn die Kräfte der extremen Rechten müßten sich nun - wollten sie politisch aktiv werden - nolens volens in die zugelassenen bürgerlichen Parteien integrieren. Dadurch sei die "old Weimar division“ zwischen demokratischen und nationalistisch-antidemokratischen Parteien der bürgerlichen Rechten verschwunden, so daß sich die Arbeiterparteien nun einem relativ homogenen Block bürgerlicher Parteien gegenübersähen. Obwohl in diesem Lager durchaus Differenzen bestünden, würden diese von einigen gemeinsamen vitalen Interessen überdeckt etwa der „salvation of the existing social structure, the protection of private property, and opposition to the predominance of labor".

Für R\&A ergab sich daraus insgesamt eine Polarisierung: „more clearly than ever" sei das politische Spektrum in eine Rechte und eine Linke gespalten, und deutlicher als je zuvor folge diese Spaltung den „traditional class lines of German society“ das Bürgertum sei durch die Christdemokraten und die Liberalen repräsentiert; ihnen gegenüber stehe die Arbeiterschaft, -vertreten durch SPD und Kommunisten. Als die in der Studie eingangs erwähnten ,indirekten“ politischen Kräfte waren die Handelskammern in diesem Spektrum der Rechten, Gewerkschaften und Betriebsräte der Linken zuzuordnen. Die politische Mitte sei verschwunden "[as] result of the Nazi period, which brought about the gradual destruction of the economic basis of the old middle class“. Diese Polarisierung bedeutete nach Ansicht von R\&A allerdings nicht unbedingt eine Radikalisierung: "Neither of the two labor parties is any more revolutionary than in the years prior to 1933 , and their efforts to absorb at least a part of the dislodged middle classes and of the rural population are likely to strengthen their democratic and reformist tendency. Moreover, the conditions of occupation and the state of the German masses seem to preclude any organized revolutionary movement." 
Längerfristig gesehen konnte sich R\&A sogar eine Verschiebung der an sich als so grundsätzlich beschriebenen Aufspaltung des Parteienspektrums in einen bürgerlichen Parteienblock einerseits und einen Block der Arbeiterparteien und der Kommunisten andererseits durch die Absorption der SPD in das bürgerliche Lager vorstellen: „The tradition, the present attitude, and the leadership of the SDP seem to justify the prediction that, as German political life assumes more independent form and content, the SDP will move toward a bourgeois front against Communists."

Gleichzeitig glaubte R\&A aber, daß die traditionellen Klassengegensätze in Deutschland dauerhaft bestehenbleiben würden. Obwohl unter den Bedingungen der Besatzung politische Kontroversen bislang nur indirekt ausgetragen werden könnten, zeichneten sich die zwischen der Rechten und Linken strittigen politischen Grundfragen bereits ab, wobei es nach Ansicht von R\&A letztlich um den demokratischen Wiederaufbau der Wirtschaft ging. In diesem Zusammenhang würde sich zunächst die Frage nach Ausmaß und Schärfe der Entnazifizierung stellen, da eine gründliche Entnazifizierung ein Aufbrechen der Machtkonzentrationen in Industrie und Kapital erfordere; damit stelle sich auch die Frage nach dem Schutz des Privateigentums als gesellschaftlicher Grundlage; schließlich erfordere eine Demokratisierung der Wirtschaft auch mehr Einfluß und bessere Repräsentation der Arbeiter. In diesen Fragen werde wiederum die unterschiedliche Politik der einzelnen Besatzungsmächte entscheidenden Einfluß haben. So habe die Besatzungsmacht in der sowjetischen Zone die Kommunisten bereits dabei unterstützt, durch die Bodenreform und die Verstaatlichung von Schlüsselindustrien die Grundlage für die Entmachtung der alten Herrschaftsschicht zu legen. In den westlichen Zonen habe die Politik der Besatzungsmächte dagegen bislang keine vergleichbar fundamentalen gesellschaftlichen Veränderungen begünstigt. Grundsätzlich war es nach Ansicht von R\&A aber unabdingbar, eine Konsolidierung der Macht der „old ruling groups“ zu verhindern, denn falls dies nicht gelänge, wollte R\&A „an open struggle within Germany, with possible repercussions on the international level“, keineswegs ausschließen.

Andererseits hielt es die Abteilung aber durchaus für möglich, daß die notwendigen Veränderungen auf demokratisch-administrativem Wege durchgeführt werden könnten. In diesem Zusammenhang entwarf R\&A freilich das Bild eines von einer „bourgeois-labor coalition" regierten Deutschland, in dem die notwendige Demokratisierung der Wirtschaft auf ein Minimum beschränkt würde und die traditionellen Konflikte bestehenblieben. Diese würden sich letztlich auf die Alternative zwischen Staatskapitalismus und Staatskommunismus zuspitzen, wobei die Konsequenzen dieses Antagonismus nach Ansicht von R\&A in hohem Maße von den Entwicklungen auf internationaler Ebene beeinflußt werden würden und insofern nicht abzuschätzen seien.

Während der hier unternommene Versuch, künftige Entwicklungen unter Anwendung einer marxistischen Gesellschaftstheorie zu prognostizieren, in mancherlei Hinsicht unbefriedigend bleibt, bietet diese Arbeit nichtdestoweniger eine in vielen Punkten interessante, oft scharfsinnige und in Anbetracht des Zeitpunkts ihres Entstehens zuweilen bemerkenswert hellsichtig erscheinende "Zwischenbilanz am Ende des Anfangs ${ }^{\star 56}$. Auch vor dem Hintergrund der von R\&A im Rahmen der deutschlandpoliti-

${ }^{56}$ Borsdorf/Niethammer (Hrsg.), Zwischen Befreiung und Besatzung, S.273. 
schen Diskussion der letzten beiden Kriegsjahre eingenommenen Positionen verdient diese Studie besonderes Interesse. Die Entwicklungen des Jahres 1945 boten R\&A eine erste Möglichkeit, die Validität mancher der von der Abteilung formulierten Erwartungen, Prognosen und Warnungen zu überprüfen, um sie entweder als unzutreffend oder obsolet zu verwerfen, oder aber an sie anzuknüpfen, und insofern bietet diese Arbeit erste Hinweise darauf, welche Perspektiven und Positionen R\&A für die Nachkriegszeit einnahm.

Betrachtet man diese Analyse des wiedererwachenden politischen Lebens in Deutschland als Fortsetzung der von R\&A während der Kriegsjahre verfaßten Arbeiten, so erscheint sie vielleicht weniger hellsichtig, als sie für sich allein genommen scheinen könnte. Schon in den im Laufe des Jahres 1944 entstandenen Arbeiten hatte R\&A immer wieder vor der Ausprägung eines Ost-West-Antagonismus im besetzten Deutschland gewarnt und versucht, dessen mögliche Konsequenzen in ihren komplexen Wechselwirkungen auf die politischen Entwicklungen in Deutschland und Europa und damit auch im internationalen Rahmen zu skizzieren. R\&A konnte sich nun in vielen Befürchtungen bestätigt sehen, und tatsächlich verweisen einige Formulierungen und Argumentationsweisen dieser Analyse sehr deutlich auf frühere Arbeiten.

Doch während sich die Kassandrarufe der Abteilung als vollauf berechtigt erwiesen, mußte sich R\&A in den Erwartungen an eine für tiefgreifende soziale Umwälzungen streitende Linke getäuscht sehen. Freilich hatten die R\&A-Deutschlandexperten andererseits selbst früh $Z$ weifel an der revolutionären Energie der Linken gezeigt und schon im Sommer 1944 das Bild entworfen, dessen Ausformung man ein Jahr später zu beobachten glaubte ${ }^{57}$. Diese frühen $Z$ weifel mögen dazu beigetragen haben, daß R\&A in der Unterdrückung der "Antifas" durch die Militärregierungen nun nicht den entscheidenden Faktor für das Zerbröckeln der antifaschistischen Front sah. Weitaus schwerwiegender erschien nach Darstellung der Abteilung das Wiederaufbrechen der sozialen und politischen Konflikte, die die Weimarer Republik nicht hatte lösen können und die der Nationalsozialismus nur unterdrückt oder, wie in manchen R\&AStudien in Anlehnung an die von Neumann in Behemoth formulierten Thesen angeklungen war, gar verschärft hatte.

Bei der Darstellung und Analyse der in diesem Zusammenhang relevanten Entwicklungen blieb R\&A nun merkwürdig gespalten. Man versuchte, die schon 1944 als Eventualität skizzierte, nun als die wesentlichste Neuerung des sich in Deutschland bzw. in den westlichen Besatzungszonen entwickelnden politischen Lebens erscheinende Tendenz einer Ausweitung des bürgerlichen Lagers durch das Ineinandergreifen einer Vielzahl von Faktoren zu erklären. So wurde diese Entwicklung sowohl als Folge des NS-Regimes als auch beeinflußt durch die Bedingungen der Nachkriegszeit dargestellt; im Hinblick auf die Nachkriegssituation wurde einerseits auf die Gegeben-

\footnotetext{
57 Auch Neumann hatte die in R\&A-Studien immer wieder formulierten Erwartungen an die Arbeiterschaft bzw. die Linke bereits im September 1944 in Frage gestellt, als er in einem Entwurf zum Thema "How to Weaken Germany" in Zweifel zog, daß damit gerechnet werden könne, "that during or after the collapse of Nazism, democratic forces will emerge and will be able to establish themselves. It is possible that Nazism has not only destroyed the democratic organizations [...] but has exterminated the active and most of the potential revolutionary leaders and killed the revolutionary spirit for some time to come“. In: NA, RG 226, E 74, b 2, f: Germany-Peace.
} 
heiten in einem durch Krieg zerstörten Land, andererseits auf die durch Besatzung und Militärregierung geschaffenen Verhältnisse verwiesen, und in diesem Zusammenhang wurde wiederum die spezifische Form der Kontrolle durch vier verschiedene, zum Teil antagonistische politische Strategien verfolgende Mächte besonders berücksichtigt. Doch während Deutschland in dieser Darstellung bereits als politisch geteilt erscheint, unterschätzte R\&A die Auswirkungen einer Verfestigung dieser Teilung gerade für die Entwicklung der Linken in den Westzonen. Die von R\&A formulierten Prognosen für die weitere Entwicklung reflektierten dann die vorher beschriebene Komplexität der Situation in Deutschland kaum, sondern folgten einer schon geradezu orthodoxen marxistischen Argumentation: So bestand R\&A darauf, daß sich die Klassengegensätze im Nachkriegsdeutschland zunehmend schärfer ausprägen würden, wobei nicht ausgeschlossen wurde, daß sich der "Klassenkampf“ - ganz buchstäblich als „open struggle“ - an der Konsolidierung der Macht der "old ruling groups“ entzünden könnte. Obwohl R\&A es andererseits auch für möglich hielt, daß die Klassengegensätze durch demokratisch-administrative Minimalreformen vorläufig überdeckt werden könnten, um erst in ferner Zukunft aufzubrechen, verstellte das Beharren auf einer rigiden marxistischen Perspektive R\&A den Blick dafür, daß der „Klassenkampf “ angesichts eines sich verschärfenden Ost-West-Antagonismus in den Hintergrund treten und in den Westzonen durch eine deutsche Version des „New Deal“ gegenstandslos werden könnte.

Dennoch ist das von R\&A gezeichnete Bild der Entwicklungen in Deutschland 1945 insgesamt komplexer, als bisherige Arbeiten, deren Interesse vor allem der Frage nach dem Einfluß der in R\&A beschäftigten Emigranten galt, haben erkennen lassen. Die direkte Konfrontation mit dem so lange nur indirekt zugänglichen "Studienobjekt" Deutschland bestätigte eher die Befürchtungen als die Hoffnungen der Abteilung und beraubte R\&A damit gewissermaßen der politischen Identifikationsfigur. Nicht übersehen werden darf in diesem Zusammenhang, daß R\&A die Entwicklungen im besetzten Deutschland von Anfang an als nicht nur von den Besatzungsmächten bestimmt verstand, sondern schon sehr früh eine - wenn auch ungleichgewichtige - Interaktion zwischen Besatzern und Besetzten beschrieb. Damit erfaßte R\&A, was in der neueren Fachliteratur häufig als „das historisch Wesentliche der Besatzungszeit" erscheint ${ }^{58}$, und konnte so auch schon die in der Literatur erst in den letzten Jahren intensiver untersuchte Frage stellen, inwieweit die sich in der „Zusammenbruchgesellschaft“ manifestierenden Mentalitäten, Strukturen und Tendenzen die Realisierung der Zielvorstellungen alliierter Besatzungspolitik begünstigten oder unterstützten, modifizierten oder behinderten ${ }^{59}$.

Die „Nahaufnahmen“ von R\&A/Germany ließen erkennen, daß die soziale Revolution, auf die R\&A gehofft hatte, nicht nur deshalb nicht in Gang kam, weil sie im politischen Programm der westlichen Besatzungsmächte nicht vorgesehen war bzw. weil politisch konservative, oder einfach nur überarbeitete und überforderte Besatzungsoffi-

${ }^{58}$ Hier nach Kleßmann, Die doppelte Staatsgründung, S. 66.

59 Vgl. dazu z. B. die kurzgefaßten Überlegungen Gimbels, Amerikanische Besatzungspolitik und deutsche Tradition, in: Herbst (Hrsg.), Westdeutschland 1945-1955, S. 147-150. Die extremste Position in der Debatte um die Frage, inwieweit sich deutsche Traditionen gegenüber alliierter Einflußnahme als resistent erwiesen, hat wohl Peterson vertreten: The American Occupation of Germany. 
ziere sie direkt oder indirekt unterbanden, sondern auch deshalb nicht, weil die Mehrheit der Deutschen viel zu apathisch, zu autoritätshörig und überdies viel zu sehr von der Sorge ums tägliche Überleben in Anspruch genommen war, um revolutionäre Energien für den Kampf um eine bessere Zukunft aufzubringen - zumal diejenigen, die diesen Kampf nach Vorstellung von R\&A hätten anführen müssen, nach zwölf Jahren Bedrohung und Isolation selbst viel zu desorientiert schienen, um die Initiative zu ergreifen.

War R\&A noch in den Arbeiten für das War Department recht engagiert für die deutsche Linke eingetreten, so äußerte man sich nun nicht gleichermaßen engagiert kritisch, wenn die Besatzungsbehörden die entsprechenden Empfehlungen nicht beherzigten. Zwar haben einige R\&A-Mitarbeiter rückblickend gemeint, daß alles hätte anders kommen können, wenn die Militärregierung die "Antifas“ nicht unterdrückt hätte ${ }^{60}$, doch finden sich in den R\&A-Arbeiten selbst keine derartig eindeutigen „Schuldzuweisungen “. Der Tenor der seit 1945 entstehenden Arbeiten deutet eher darauf hin, daß man zu der Ansicht - wenn man will: Einsicht - gekommen war, daß die von der Abteilung erhoffte "social revolution“ in Deutschland eben nicht nur deshalb nicht stattfand, weil die Alliierten sie im Westen unterbanden und im Osten manipulierten, sondern weil die Kräfte, auf die R\&A gesetzt hatte, eine Minderheit darstellten und zudem kaum über die notwendige politische Vitalität verfügten ${ }^{61}$. Damit waren die von R\&A entwickelten Vorstellungen vorerst ins Reich der Utopie verwiesen, und die Distanz, die in den R\&A-Deutschlandanalysen zunehmend erkennbar wird, mag sehr wohl diese Erkenntnis reflektieren.

Insgesamt scheint es somit fragwürdig, ob die seit 1945 entstehenden Arbeiten der Abteilung noch immer in erster Linie als Arbeiten deutscher Emigranten, die ein ,anderes Deutschland“ befördern wollten, interpretiert werden können ${ }^{62}$. In diesem Zu-

${ }^{60}$ So z. B. Herz, Denazification and Related Policies, in: ders. (Hrsg.), From Dictatorship to Democracy, S.24f.; eine ambivalentere Sicht findet sich bei Krieger, The Inter-Regnum, in: PSQ (LXIV, 1949), S. $513 \mathrm{f}$. Überaus interessant sind in diesem Zusammenhang auch die Positionen, die Franz Neumann in einer Reihe von Artikeln vertrat, in denen er sich zwischen 1947 und 1950 mit den Entwicklungen in Deutschland auseinandersetzte: Neumann, Wirtschaft, Staat, Demokratie, S. $290 \mathrm{ff}$.

61 Ausführlicher dazu VIII., 1. und 3. Teil. Neumann sollte 1948 feststellen: „Natürlich hat die Militärregierung die Deutschen nicht dazu ermutigt, ihre Reihen von den Faschisten selbst zu säubern [...] Trotzdem ist es verblüffend, daß es, abgesehen von vereinzelten AntifaschismusKomitees, keine Explosion antifaschistischer Gefühle gegeben hat, keinen spontanen Umschwung, keine Demonstration des Willens, um jeden Preis voranzuschreiten." In: Neumann, Militärregierung und Wiederbelebung der Demokratie, in: ders., Wirtschaft, Staat, Demokratie, S. 315 f.; vgl. jedoch oben Anmerkung 57.

${ }^{62}$ So, wie bereits mehrfach angesprochen, die Söllners Interpretationen zugrundeliegende Annahme, vgl. ders. (Hrsg.), Archäologie der Demokratie, z. B. in Bd.1, S.7ff., Bd.2, S.113ff. Mit Blick auf die nach Kriegsende ausgearbeiteten Deutschlandanalysen argumentiert Söllner, daß die Emigranten in R\&A (bzw. in den R\&A-Nachfolgeorganisationen im State Department) auf "das wichtigste Resultat der ersten Besatzungsmonate“ - nämlich die Erkenntnis, daß die Militärregierung nicht das geeignete Medium sei, um "die Reste an Arbeiterbewegung, in denen ein kämpferischer Antifaschismus am Leben geblieben war, zum Ausgangspunkt der demokratischen Rekonstruktion“ zu machen - „in einer defensiven Weise, mit der strategischen Zurückhaltung in der politischen Perspektivenbildung reagierten“. (Bd.2, S.113) Vgl. zu dieser Problematik auch Söllners Überlegungen in: Wissenschaftliche Kompetenz und politische Ohnmacht, in: Koebner/Sautermeister/Schneider (Hrsg.), Deutschland nach Hitler, S. 136-150. 
sammenhang dürfte es nicht ohne Bedeutung sein, daß sich die meisten dieser Emigranten inzwischen entschlossen hatten, nicht nach Deutschland zurückzukehren, sondern sich - wenn auch vielleicht als "permanent exiles" - in den USA niederzulassen ${ }^{63}$.

\section{Die Vorbereitung der Nürnberger Kriegsverbrecherprozesse}

Obwohl die von den Nationalsozialisten in den von Deutschland besetzten Gebieten verübten Greueltaten schon bald nach Beginn des Krieges den Ruf nach Bestrafung provoziert hatten, hielten sich die Alliierten in dieser Frage lange bedeckt. Im Januar 1941 hatten zunächst neun europäische Exilregierungen in der von ihnen gemeinsam verabschiedeten Erklärung von St. James unter Berufung auf die Haager Konvention „die Bestrafung der für diese Verbrechen Verantwortlichen, gleichgültig, ob die Betreffenden diese Taten anordneten, sie selbst begingen oder irgendwie daran teilnahmen", als eines der Hauptkriegsziele bezeichnet und gefordert, daß die Schuldigen vor Gericht gestellt und abgeurteilt werden sollten ${ }^{64}$. Doch erst nachdem im Oktober 1943 die United Nations War Crimes Commission begründet worden war, erklärten schließlich die USA, Großbritannien und die Sowjetunion in der Moskauer Deklaration im November 1943 offiziell ihre Absicht, Kriegsverbrecher in den Staaten vor Gericht zu stellen, in denen sie sich schuldig gemacht hätten, und Verbrechen umfassenderer Natur, die nicht an einen bestimmten Ort gebunden waren, nach einem noch festzulegenden Verfahren zu ahnden.

Seit dieser Absichtserklärung konnte die Bestrafung von Kriegsverbrechen zwar tatsächlich als erklärtes Kriegsziel der Alliierten gelten, doch ähnlich wie bei den meisten anderen Kriegszielen fehlten konkrete Vorstellungen oder gar Planungen zu seiner Realisierung. Immerhin begann man im Herbst 1943 im US-Justizministerium, Unterlagen für eventuelle Prozesse zu sammeln ${ }^{65}$, und Ende Oktober 1943 erkundigte sich Präsident Roosevelt bei Donovan, ob und inwieweit man sich im OSS mit der Frage der Kriegsverbrecherprozesse auseinandergesetzt habe ${ }^{66}$. Donovan sandte ihm daraufhin unverzüglich eine im OSS ausgearbeitete Denkschrift zu und verwies darauf, daß eine Liste deutscher Kriegsverbrecher bereits in Bearbeitung sei; Roosevelt seinerseits leitete die OSS-Denkschrift an den Außenminister weiter und erkundigte sich auch bei ihm nach dem "present status of the war criminals , trials"“.

Diese Initiative fand zunächst wenig Widerhall, und letztlich blieb bis zum Ende des Krieges offen, in welcher Form die deutschen Kriegsverbrechen geahndet werden sollten, ja wie sie rechtlich überhaupt zu definieren und zu verfolgen wären. Die noch während des Krieges, nämlich bereits Ende 1943 in Kiew und Charkow von den Sowjets durchgeführten Kriegsverbrecherprozesse waren in Washington als Verstoß gegen die Genfer Konvention zur Behandlung von Kriegsgefangenen kritisiert worden;

${ }^{63}$ Die Charakterisierung als "permanent exiles" nach Jay, Permanent Exiles.

${ }^{64}$ Hier zit. nach Heydecker/Leeb, Der Nürnberger Prozeß, I, S. 86; siehe zum Folgenden auch ebenda, S.87f., sowie Smith, The American Road to Nuremberg, und ders., Der Jahrhundertprozeß, S. $32 \mathrm{ff}$.

65 Siehe z. B. Kempner, Ankläger einer Epoche, S. $206 \mathrm{ff}$.

${ }^{66}$ Dazu und zum Folgenden FDRL, PSF/Subject, b 167, Korrespondenz vom 25., 27. und 29.10. 1943. 
andererseits gab es in Großbritannien wie in den USA durchaus angesehene Politiker, die sich gegen gerichtliche Verfahren aussprachen und statt dessen für die standrechtliche Erschießung der als Hauptkriegsverbrecher geltenden Personen und Zwangsarbeit für Mitglieder der SS und anderer notorischer NS-Organisationen plädierten.

In Washington war es vor allem Finanzminister Morgenthau, der mit den nationalsozialistischen Kriegsverbrechern auf diese Weise „kurzen Prozeß $\AA^{4}$ machen wollte ${ }^{67}$. Die von ihm Ende August 1944 formulierten Vorschläge brachten die seit der Moskauer Deklaration vom November 1943 fast völlig vernachlässigte Diskussion um die ins Auge gefaßten Kriegsverbrecherprozesse wieder in Gang. Vor allem im War Department konnte man Morgenthaus diesbezüglichen Vorschlägen nicht viel abgewinnen, und Kriegsminister Stimson, der sich für Fragen des Völkerrechts interessierte, begann, vehement für die Aburteilung der obersten NS-Führer vor einem internationalen Tribunal einzutreten. Im Rahmen der nun im War Department vorangetriebenen Planungen versuchte man, die mit diesem Verfahren verbundenen rechtlichen und verfahrenstechnischen Probleme dadurch in den Griff zu bekommen, daß man für die führenden Nationalsozialisten einen großen Hauptprozeß vorschlug, in dem sie der "Verschwörung" sowie der Begründung bzw. Leitung nkrimineller Vereinigungen" angeklagt werden sollten, während das Strafmaß für die Mitglieder dieser „kriminellen Vereinigungen" in Nachfolgeprozessen festgelegt werden sollte.

Obwohl dieser Ansatz in den folgenden Monaten überaus kontrovers diskutiert wurde und im Verlaufe dieser Diskussion auch immer wieder Modifikationen erfuhr, blieben wesentliche Elemente der im War Department entwickelten Konzeptionen in der im Vorfeld der Konferenz von Jalta ausgearbeiteten Denkschrift zur "Anklage und Bestrafung der Nazikriegsverbrecher" erkennbar ${ }^{68}$. In Jalta wurde dieses Papier allerdings nicht diskutiert, und es war schließlich auch nicht mehr Roosevelt, der die offizielle amerikanische Position in dieser Frage entschied. Wenige Tage nach Roosevelts Tod billigte jedoch sein Nachfolger Harry S. Truman die in Vorbereitung der Konferenz von Jalta ausgearbeitete Denkschrift als Richtlinie für die amerikanische Politik gegenüber den Hauptkriegsverbrechern, und Anfang Mai bestellte er Richter Jackson vom Obersten Bundesgericht zum „Hauptankläger im Verfahren gegen Verbrecher der Achsenmächte".

Jackson seinerseits verpflichtete unverzüglich Donovan als Mitglied der Anklagevertretung und erwarb damit auch die Dienste des OSS ${ }^{69}$. Donovans Behörde konnte zur Vorbereitung der geplanten Prozesse in mehrfacher Hinsicht beitragen. Zum einen ent-

${ }^{67}$ Die Verschärfung der Deutschlandplanung im Sommer 1944 muß wohl auch vor dem Hintergrund einer durch Zeitungsberichte über Majdanek - dem ersten von der Roten Armee befreiten Konzentrationslager - erregten öffentlichen Meinung gesehen werden, vgl. dazu Buscher, The U.S. War Crimes Trial Program in Germany, S. 15.

${ }^{68}$ FRUS, Malta and Yalta, S. $402 \mathrm{f}$.

${ }^{69}$ Dazu und zum Folgenden NA, RG 226, E 37, b 6, f: War Crimes Program; NA, RG 226, E 1, b 2, f: War Crimes: Korrespondenz Mai - Juli 1945; NA, RG 226, E 42, b 1, R\&A/Europe-Africa Division progress report, Mai 1945; Smith, Jahrhundertprozeß, S. 32 ff., sowie Katz, Foreign Intelligence, $S .51 \mathrm{ff}$ - Im Nürnberger Prozeß selbst sollte Donovan allerdings keine Rolle spielen, denn er trat bereits kurz nach seiner Eröffnung Ende November wegen Meinungsverschiedenheiten mit Jackson zurück, siehe dazu Smith, Jahrhundertprozeß, S. 194 f., 295 ff.; Kempner, Ankläger einer Epoche, S. 212. 
hielten die vom OSS gesammelten Meldungen zuweilen Hinweise auf Kriegsverbrechen ${ }^{70}$, darüber hinaus bemühten sich die "Document Collecting Teams" von R\&A/ Germany um die Sicherstellung eventuell relevanter Unterlagen, und auch in OSS/ London wurden entsprechende Materialien zusammengetragen ${ }^{71}$; zum anderen hatte R\&A bereits eine Reihe von Studien ausgearbeitet, die als Prozeßmaterialien geeignet waren $^{72}$.

Im Rahmen der von Morgenthau wieder entfachten deutschlandpolitischen Debatte hatte man sich zudem auch in R\&A mit der Frage beschäftigt, wie die vom bestehenden Recht nicht abgedeckten "Problems Concerning the Treatment of War Criminals" gelöst werden könnten ${ }^{73}$, und Ende September 1944 skizzierten die R\&ADeutschlandexperten eine Strategie, die darauf abzielte, die Nationalsozialisten mit ihren eigenen Waffen zu schlagen: „Because of the peculiar structure of the Nazi state and because of the ,leadership principle under which Hitler and his associates lay down broad fundamental principles but leave wide discretion in execution to their subordinates, [...] lack of specific knowledge of a criminal act or its execution, or of an order authorizing it, should not be accepted as a defense to a charge involving a war crime." 74

70 Z.B. NA, RG 226, 3935: Italy and Germany - Domestic Situation, 6.9. 1941; NA, RG 226, 76527: German War Criminals in Occupied Yugoslavia, 12.1. 1944; NA, RG 226, 58852: Sachsenhausen Concentration Camp [1944]; NA, RG 226, 102832: German Execution of Jews in Occupied Russia, 23.8. 1944.

71 NA, RG 226, E 91, b 8 (War Diary, R\&A/London, Vol. III, Part 3, S.269ff.); NA, RG 226, $\mathrm{E} 115, \mathrm{~b} 48, \mathrm{f} 2$. Die von OSS/London gesammelten Unterlagen entsprechen offenbar der R-Serie der für den Nürnberger Prozeß zusammengestellten Dokumente, siehe dazu War Crimes, War Criminals, and War Crimes Trials, S.19. Die Dokumente der R-Serie sind abgedruckt in Der Prozeß gegen die Hauptkriegsverbrecher, Bd. XXXVIII, S. 236-498.

$72 \mathrm{Vgl}$. die in NA, RG 238, E 52f, b 26-29 enthaltenen R\&A-Materialien, z. B. die Serie R\&A 2500.1(-23), „German Military Government over Europe“, Dezember 1944-April 1945. Aus einer Broschüre der Wiener Library, Tel Aviv, geht außerdem hervor, daß die OSS Field Photographic Branch auch Ausschnitte aus Wochenschauen als Beweismaterial vorbereitete, vgl. Newsreels from 1933 to 1944, showing how Nazis prepared, started and prolonged the Second World War; die Filme selbst sind jedoch nicht vorhanden. - Laut Smith, Jahrhundertprozeß, S.66, war allerdings „das vom OSS gelieferte Material [...] praktisch unbrauchbar“; Smith begründet diese Beurteilung jedoch nicht näher. Franz Neumann erwähnt dagegen in einem Schreiben an Langer am 22.5. 1945, daß sich Richter Jackson positiv über die vom OSS bzw. R\&A geleistete Arbeit geäußert habe, in: NA, RG 226, E 1, b 3, f: Europe-Africa Division 1945.

73 Vgl. dazu NA, RG 238, E 52f., b 28, R\&A 2577, „Problems Concerning the Treatment of War Criminals“, 28.9. 1944, und R\&A 2577.2, „Problems Concerning the Treatment of War Criminals; List of Potential War Criminals Under Proposed US Policy Directives", 30. 9. 1944.

${ }^{74}$ So problematisch diese Interpretation für die juristische Praxis sein mochte, so interessant ist wissenschaftsgeschichtlich, daß R\&A hier - möglicherweise in Weiterentwicklung des von Neumann in Behemoth als näußerste Formlosigkeit “ beschriebenen Auflösungsprozesses rechtsstaatlicher Rationalität - argumentierte, daß das Führerprinzip keineswegs eine straffe Aufgabendelegation von oben nach unten bedeutete, sondern vielmehr eine Kompetenzerweiterung der „Unterführer" zur Folge hatte. Es sollte Jahrzehnte dauern, bis zeitgeschichtliche Detailstudien die hier schon angedeuteten „anarchischen“ Züge bzw. polykratischen Strukturen des NS-Staates belegen konnten; in der deutschen Historiographie erstmals dazu: Schulz, Die Anfänge des totalitären Maßnahmenstaates, insbesondere S. $279 \mathrm{ff}$; vgl. danach Broszat, Der Staat Hitlers, insbesondere S. $9 \mathrm{f}$. und $363 \mathrm{ff}$. 
Nachdem Donovan im Mai 1945 von Jackson zum Mitglied der Anklagevertretung ernannt worden war, spezialisierten sich die R\&A-Deutschlandexperten darauf, diese Argumentation weiterzuentwickeln. In einer Studie mit dem Titel „Leadership Principle and Criminal Responsibility “75 begründete R\&A die Verantwortung der Machtund Entscheidungsträger des nationalsozialistischen Deutschlands z.B. mit Zitaten aus Hitlers Mein Kampf: „Hitler has said: ,Whoever wants to be a leader has with the highest and unlimited authority also the ultimate and heaviest responsibility." Wie R\&A ausführte, folgte aus den NS-Lehren, „[that] the leader has to answer for what those entrusted to his leadership do, even if, in some particular case, they have acted against instructions and without any concurring (intent or negligence) on the part of the leader“. Als Beleg wurde aus einer „Führungsordnung des deutschen Volkes“ zitiert: "There is a deeper meaning in the fact that an officer can under no circumstances use the excuse that his men have failed [...] The genuine leader regards the guilt of his followership as his own and accepts it, even if, as the case may be, he has been really without guilt himself. He himself may make responsible those who have actually failed, but toward his superiors he alone is the guilty one. Only thus one can understand the principle of authority over those below, responsibility to those above in all its profound meaning. “

Nicht ohne Häme argumentierte R\&A, daß der "tiefere Sinn“ des so verstandenen Führerprinzips es rechtfertige, vor allem diejenigen zur Verantwortung zu ziehen, die im NS-System höhere Führungspositionen innegehabt hatten. Die ihnen Untergeordneten seien dagegen - zumal in einem Terror-Regime, wie es die NS-Diktatur darstellte - als ihrer Entscheidungs- und Handlungsfreiheit beraubt anzusehen: „They have become more or less automatons through physical or psychological influence, and their actions should legally be attributed to those who have used these means of influence."

Als „Anwendungsbeispiel“ für diese Konzeption führte R\&A den Genozid an den Juden an: „For example: If a general policy adopted on the highest level of leadership has been to the effect to ,eliminate all Jews from European life once and for all', and if in pursuance of such policy a large part of the Jewish population under Nazi rule has actually been exterminated, the acts of physical extermination may be attributed to all leaders and sub-leaders who, under the highest leadership, had functional and regional jurisdiction in connection with the implementation of the Jewish policies of the Nazi regime. All of them can be presumed to have known the Nazi program and the Nazi policies in this respect, all of them have used their positions to implement them, and all of them have known that in the execution of policy directives no legal restrictions would be observed. Whether or not under such conditions, they have been aware of the particular details of execution in specific cases, appears immaterial."

Besonders bemerkenswert an der von R\&A hier entwickelten Argumentation ist, daß sie die von den in Nürnberg Angeklagten später am häufigsten gebrauchten Ausflüchte vorwegnahm und sie - juristisch freilich auf problematische Weise - widerlegte bzw. zurückwies. Doch so befriedigend und verlockend es auch sein mochte, den NS„Führern" aus ihrer eigenen Ideologie im wahrsten Sinne des Wortes einen Strick zu

75 NA, RG 238, E 52f., b 28, R\&A 3110, „Leadership Principle and Criminal Responsibility“, 18.7. 1945; in deutscher Übersetzung bei Söllner(Hrsg.), Archäologie der Demokratie, Bd. 1, S. 173-183. 
drehen, war dieses Vorgehen nur schwer mit angelsächsischen Rechtsvorstellungen zu vereinbaren, zumal R\&A ganz unverblümt mit zweierlei Maß messen wollte: Während die strafrechtliche Verantwortung der "Führer" unter Anwendung der NS-Ideologie definiert werden sollte, würden diese sich selbstverständlich nicht auf das aus dieser Ideologie folgende „Rechtsverständnis“ berufen können.

Dieser eher unbekümmerte Umgang mit Rechtsnormen war freilich nicht auf R\&A beschränkt, sondern reflektierte die auch in vielen anderen, mit der Vorbereitung der geplanten Kriegsverbrecherprozesse befaßten Gremien verbreitete Überzeugung, daß die von den Nationalsozialisten begangenen Verbrechen nur dann gerichtlich verfolgt werden könnten, wenn man bereit war, innovative Interpretationen bzw. Erweiterungen bestehender rechtlicher Bestimmungen zuzulassen. R\&A dürfte freilich besonders prädestiniert gewesen sein, die in NS-Schriften entwickelten Begründungen des „Führerprinzips" gegen dessen Nutznießer zu wenden, denn R\&A konnte dabei auf die eigenen Analysen der Machtstrukturen im nationalsozialistischen Deutschland aufbauen, um - wie schon in den von der Abteilung entwickelten Konzeptionen zur Entnazifizierung - zu versuchen, die Eliminierung der Herrschaftselite als vorrangige Aufgabe alliierter Säuberungsmaßnahmen zu definieren.

Wie bei anderen Auftragsarbeiten hatte sich R\&A aber auch bei der Arbeit für die War Crimes Commission an den durch bisherige Planungen und Absprachen bereits abgesteckten Rahmen zu halten. So reflektiert ein von R\&A Anfang Juni vorgelegter Projektentwurf zu einer Reihe von Studien über die „Principal Nazi Organizations Involved in War Crimes ${ }^{\text {"76 }}$ das im War Department entwickelte - und während der Beratungen in London später kritisierte - Konzept einer nationalsozialistischen „Verschwörung ", wobei unterstellt wurde, daß das NS-Regime bzw. seine tragenden Organisationen an sich verbrecherischen Charakters waren, also von vornherein als Instrumente zur Ausführung von Verbrechen gedacht waren. Dabei wurde keineswegs verschwiegen, daß diesem Ansatz nicht zuletzt pragmatische Überlegungen zugrundelagen, die einen Mammutprozeß mit Hunderten von Angeklagten, denen individuelle Verbrechen nachzuweisen wären, unnötig machen sollten.

Die zu ahndenden Verbrechen wurden unter vier Anklagepunkten zusammenge$\mathrm{fa}_{\mathrm{Bt}}{ }^{77}$ : „I: Plot for World Domination [... . II: Launching of Illegal Wars, Aggression and Violation of International Treaties [...] III: Violation of International Rules of Warfare [...] IV: Domestic Crimes“. Nach Ansicht von R\&A beinhaltete Anklage-

${ }^{76}$ NA, RG 238, E 52f., b 28, R\&A 3113, ,Outline of Project: Principal Nazi Organizations Involved in War Crimes", 5.6. 1945 (+ Serie) - abgedruckt in Söllner (Hrsg.), Archäologie der Demokratie, Bd.1, S. 184-201. Ausgearbeitet wurden im Rahmen dieses Projekts: NA, RG 238, E 52f., b 28, R\&A 3113.1, (Draft), "Criminal Responsibility in Connection with the Purge of 1934“, 15.6. 1945 - die nationalsozialistischen Opfer des sog. „Röhm-Putsches“ werden ausdrücklich nicht berücksichtigt, was menschlich verständlich, rechtlich aber wohl nicht unproblematisch war; 3113.1 Supplement (mit zusätzlichen Informationen zum Röhm-Putsch nach dem Manuskript von H.-B. Gisevius, der mit Dulles in Bern zusammengearbeitet hatte); NA, RG 238, E 52f., b 28, R\&A 3113.3, "Legislative Agencies Involved in War Crimes" (Draft for the War Crimes Staff), 28.8. 1945; NA, RG 238, E 52f., b 28, R\&A 3113.6, "The Gestapo“, (Draft for use of War Crimes Staff), 6.8. 1945; NA, RG 59, R\&A 3113.7, „The Nazi Party, Parts I and II", (Draft for the Use of the War Crimes Staff), 24.7. 1945.

77 Vgl. dagegen die spätere Anklageschrift in: Der Prozess gegen die Hauptkriegsverbrecher, Bd. I, S.29ff. 
punkt IV - der auch schon in den War Department-Planungen vorgesehen war - die größten juristischen Schwierigkeiten, weil er die Frage aufwarf, auf welcher Rechtsgrundlage die in Deutschland selbst begangenen Verbrechen geahndet werden sollten bzw. was als in Deutschland gültiges Recht angenommen werden sollte. An dieser Stelle sah man in R\&A einen Zusammenhang mit Anklagepunkt I, unter dem nachgewiesen werden sollte, daß die Nationalsozialisten ihre Herrschaft nur unter Verletzung geltenden deutschen Rechts hatten aufrichten können.

In einer Studie über „Nazi Plans for Dominating Germany and Europe "78 erscheint Deutschland selbst dann auch als erstes Opfer des Nationalsozialismus. Schon die nationalsozialistische Machtübernahme wird als eine Art Gewaltakt dargestellt; sie sei gegen den Willen der Mehrheit der deutschen Bevölkerung erfolgt, welche - voll und ganz, wie vermittelt wird - hinter der Weimarer Regierung gestanden habe und "against a foreign policy of aggressive expansion“ gewesen sei.

Während nicht in allen Arbeiten der Abteilung ein solches "Schwarz-Weiß“-Bild entworfen worden war, reflektierte diese fast holzschnittartige Darstellung die den meisten R\&A-Studien zum nationalsozialistischen Deutschland zugrundeliegende Sicht der deutschen Bevölkerung als einer in "ruling " und "ruled groups" geschiedenen Gesellschaft ${ }^{79}$. Obwohl Neumann in seinen Ausführungen zum „innenpolitischen Wert" des Antisemitismus sogar explizit von einer „kollektiven Schuld“ gesprochen hatte, obwohl auch die in manchen R\&A-Studien geäußerte Kritik am Versagen der Linken angesichts des aufkommenden Nationalsozialismus eine gewisse politisch-moralische Mitschuld implizierte, und obwohl schließlich in der im April 1945 vorgelegten Studie zu "Pre-Fascist Groups in Germany" breite Bevölkerungsschichten als durchaus empfänglich für die von den Nationalsozialisten propagierte Politik erschienen, hatte R\&A nie Zweifel daran gelassen, daß es letztlich ganz bestimmte Strukturen und gesellschaftliche Kräfte waren, die die Etablierung und Aufrechterhaltung des NS-Regimes ermöglicht hatten. Die Überzeugung, daß ungeachtet allen „Mitläufertums“, ungeachtet auch des Fehlens eines breiten Widerstands, doch ein grundsätzlicher Antagonismus zwischen den "ruling“ und den "ruled“ in Deutschland bestand, hatte schon den von R\&A vertretenen Konzeptionen zur psychologischen Kriegführung zugrunde gelegen; auf sie bauten dann die von der Abteilung entwickelten Vorstellungen zum Prozeß einer Demokratisierung im Deutschland der Nachkriegszeit auf, und sie prägte nun schließlich auch die Argumentation der Abteilung bei der Vorbereitung der Kriegsverbrecherprozesse, die insofern von R\&A vor allem als Bestandteil der Entnazifizierung - und damit als Grundlage der Demokratisierung - konzipiert wurden.

78 R\&A 3114, (Draft for the War Crimes Staff, in: NA, RG 238, E 52f, b 29), 7.8. 1945; dort auBerdem unter dieser Seriennummer: R\&A 3114.2, „Nazi Plans for Dominating Germany and Europe: Domestic Crimes“, 13.8. 1945 (Anhang vom 5.9. 1945); R\&A 3114.3, „Nazi Plans for Dominating Germany and Europe: The Criminal Conspiracy Against the Jews", 13.8. 1945; 3114.4, "The Nazi Master Plan, Annex 4: The Persecution of the Christian Churches“, 6.7. 1945; 3114.5, „The Nazi Master Plan, Annex 5: The Illegal Annexation of Territory by Nazi Germany“, 6.7. 1945; 3114.7, „Principal Nazi Organizations Involved in the Commission of War Crimes: Nazi Racial and Health Policy“, 15.8. 1945.

79 Vgl. dazu und zum Folgenden die vor allem in IV., 2. Teil und V., 1. Teil referierten Positionen der Abteilung. 
Freilich entsprach auch dies nur den Vorstellungen, die den amerikanischen Planungen für die Kriegsverbrecherprozesse zugrunde lagen ${ }^{80}$. Gerade die US-Planer legten großen Wert darauf, daß in den Kriegsverbrecherprozessen die Komplizenschaft weiter Kreise aus gesellschaftlich geachteten Gruppen wie Militär, Industrie und Beamtentum nachgewiesen würde. Man hoffte, damit einen „kathartischen“ Effekt zu erreichen und den Deutschen einerseits die Gefahren autoritärer politischer und sozialer Strukturen und andererseits die Vorzüge demokratischer Prinzipien vor Augen zu führen.

Doch bald nach Eröffnung des Hauptprozesses gegen „Hermann Göring und ande-

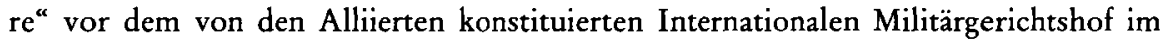
Nürnberger Justizpalast am 20. November $1945^{81}$ wurde deutlich, daß solche Hoffnungen unerfüllt bleiben würden. Der „Nürnberger Prozeß“ entwickelte sich zu einem der längsten und in seiner Dokumentation umfangreichsten, aber auch zu einem der umstrittensten Prozesse der europäischen Rechtsgeschichte ${ }^{82}$. Man konnte bald den Eindruck haben, „[that these] trials put those in charge of carrying out the program on the defensive ${ }^{\text {"83 }}$. Die zeitgenössische Kritik entzündete sich vor allem daran, daß Sieger über Besiegte zu Gericht saßen und sich dabei nicht auf einen rechtspositivistischen Standpunkt beschränken konnten, sondern versuchen mußten, über ex-postRechtsetzung den Bedingungen des totalitären Staates und des totalen Krieges Rechnung zu tragen. Diejenigen, die hofften, daß davon ein Impuls für eine entsprechende Fortentwicklung des Völkerrechts ausgehen würde, und daraus eine politische und moralische Rechtfertigung ableiteten, gerieten angesichts des sich ausprägenden Ost-WestAntagonismus bald in die Defensive und erschienen vielen bestenfalls als Idealisten.

So mochte auch die Reaktion vieler Deutscher gegenüber den Kriegsverbrecherprozessen geeignet erscheinen, den von R\&A stets angenommenen Antagonismus zwischen den „ruled“ und den "ruling groups“ nachträglich in Frage zu stellen, denn allzu viele sahen die in Nürnberg Angeklagten als Opfer einer alliierten Willkürherrschaft, die man durchaus mit der deutschen Besatzungsherrschaft vergleichen zu können glaubte ${ }^{84}$. Einige Studien der R\&A-Nachfolgeorganisationen im State Department und manche Äußerungen von ehemaligen Mitarbeitern der Abteilung illustrieren, daß man angesichts dessen - wie Hajo Holborn - zu der Überzeugung gelangte, „daß die Erwartung, die Deutschen würden einen demokratischen Glauben bereitwilligst in die

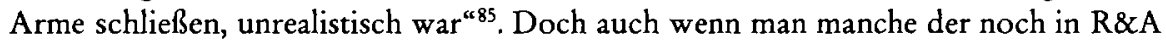
an die Prozesse geknüpfte Hoffnung und Erwartung enttäuscht sah, hätten die R\&A-

${ }^{80}$ Vgl. dazu und zum Folgenden z. B. Buscher, The U.S. War Crimes Trial Program, S.7-27, 91 ff., $159 \mathrm{ff}$.

81 Der Prozeß ist dokumentiert in Der Prozeß gegen die Hauptkriegsverbrecher (42 Bde.); einen Überblick bieten Heydecker/Leeb, Der Nürnberger Prozeß (2 Bde.).

82 Die Frage nach dem Erfolg der Prozesse als Teil der amerikanischen "reeducation" untersucht Buscher, The U.S. War Crimes Trial Program. Einen interessanten Überblick zur amerikanischen Bewertung der Nürnberger Prozesse bietet Bosch, Judgment on Nuremberg.

${ }^{83}$ Buscher, U.S. War Crimes Trial Program, S.2f.

${ }^{84} \mathrm{Vgl}$. dazu z. B. Hajo Holborn, Bericht zur deutschen Frage, dokumentiert von Erich J.C. Hahn in: VfZ 35 (1987), S. 135-166; Buscher, U.S. War Crimes Trial Program, S. $109 \mathrm{f}$.

${ }^{85}$ Ebenda, S. 148; vgl. dazu außerdem die in VIII., 1. und 3. Teil vorgestellten Studien sowie Franz Neumann, Research Notes: The War Crimes Trials, in: World Politics, Vol. II (October 1949July 1950), S. 135-147; Herz, Denazification and Related Policies, in: ders. (Hrsg.), From Dictatorship to Democracy, besonders S. $19 \mathrm{ff}$; sowie Kirchheimer, Political Justice. 
Mitarbeiter in ihrer Mehrheit wohl der später von ihrem Kollegen Otto Kirchheimer formulierten Überzeugung zugestimmt, daß der Nürnberger Prozeß - ,with all the hypocrisy and grotesqueness deriving from its very subject ${ }^{\text {" }}$ - als "morally and historically necessary operation" gelten konnte ${ }^{86}$.

Als historisch notwendig bzw. gerechtfertigt konnte der Prozeß insofern gelten, als insbesondere die Amerikaner mit ihm die Absicht verbunden hatten, die unter dem NS-Regime begangenen Verbrechen aufzuklären und zu dokumentieren. Wie schon Sherman Kent in seiner Ablehnung der von Dulles angeregten R\&A-Darstellung zum 20.Juli 1944 angedeutet hatte, war damit auch zugleich die "moralische" Absicht verbunden, dem NS-Regime „a volume of discredit which should suffice well into the future $^{\text {" }}$ auszustellen ${ }^{87}$. Auch wenn die Haltung der Deutschen nicht darauf schließen ließ, daß die Katharsis, die man sich davon erhofft hatte, eintrat, entwertete dies nicht die Absicht, sie herbeizuführen. Ihr Ausbleiben wurde in den Arbeiten der R\&ANachfolgeorganisationen freilich nicht als „Unfähigkeit zu trauern" ${ }^{\text {“88, }}$, sondern als Indiz für besorgniserregende Kontinuitäten interpretiert.

${ }^{86}$ Kirchheimer, Political Justice, S. 423.

${ }^{87}$ Siehe dazu oben S. 111, Interessant sind in diesem Zusammenhang auch Neumanns Überlegungen zum Quellenwert der Nürnberger Prozeßmaterialien für die historische Forschung: Neumann, Research Notes, in: World Politics II (Oct. 1949-July 1950), S.135ff.

${ }_{88}$ Mitscherlich, Die Unfähigkeit zu trauern. 
